\title{
Synthesis of conformationally-liberated yohimbine analogues and evaluation of cytotoxic activity
}

Han Yang, ${ }^{\dagger}$ Michal Poznik, ${ }^{\dagger}$ Shaojian Tang, ${ }^{* *}$ Peng Xue,,${ }^{\dagger}$ Lidong Du, ${ }^{\circ}$ Chenlu Liu, ${ }^{\dagger}$ Xiaochuan Chen, ${ }^{\dagger}$ and Jason J. Chruma*,†,§

${ }^{\dagger}$ Key Laboratory of Green Chemistry \& Technology (MOE), College of Chemistry and Sino-British Materials Research Institute, College of Physical Sciences \& Technology, Sichuan University, Chengdu, Sichuan, 610064, P.R. China

${ }^{\ddagger}$ School of Pharmacy, Weifang Medical University, No. 7166, Baotong West Road, Weifang, Shandong, 261053, P. R. China

"School of Public Health, Weifang Medical University, No. 7166, Baotong West Road, Weifang, Shandong, 261053, P. R. China

'School of Clinical Medicine, Weifang Medical University, No. 7166, Baotong West Road, Weifang, Shandong, 261053, P. R. China

${ }^{\S}$ Department of Chemistry, University of Virginia, McCormick Road, PO Box 400319, Charlottesville, Virginia, 22903-4319, United States

Email: chruma@scu.edu.cn or jjc5p@virginia.edu; tangsj@wfmc.edu.cn

\section{Contents}

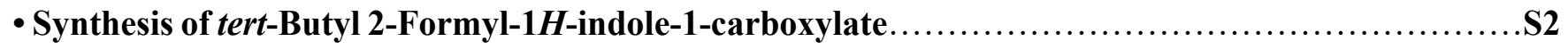

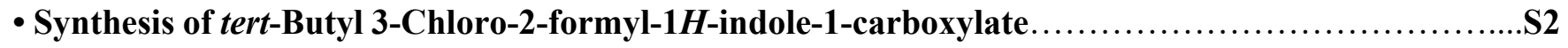

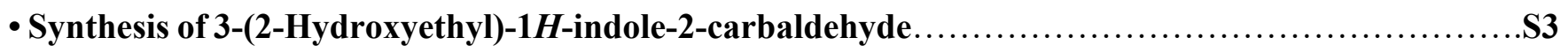

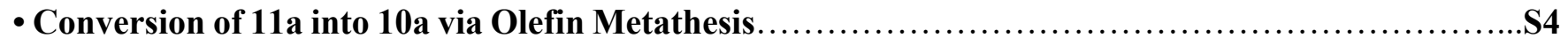

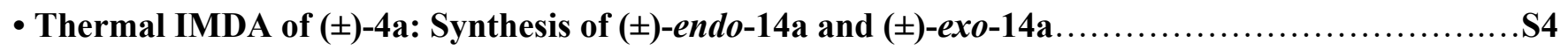

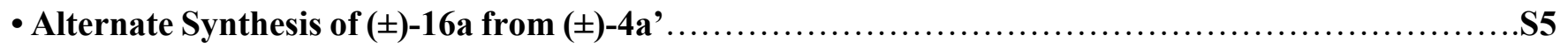

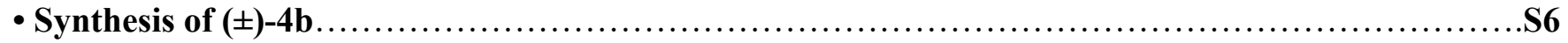

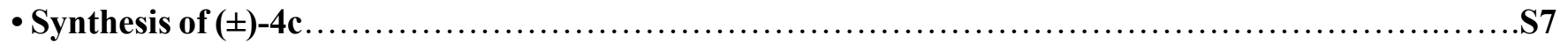

-X-Ray Crystallographic Data for $( \pm)-17+\mathrm{NaOTf}(2: 1)$ recrystallized from $\mathrm{CDCl}_{3} \ldots \ldots \ldots \ldots \ldots \ldots$. S9

- NMR Spectra for New Compounds.....................................................

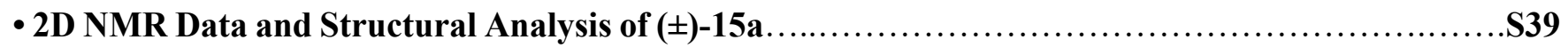

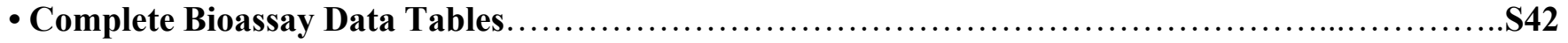

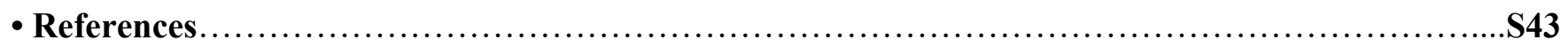


- Synthesis of tert-Butyl 2-Formyl-1H-indole-1-carboxylate

Scheme S1. Synthesis of tert-Butyl 2-Formyl-1H-indole-1-carboxylate (S4)
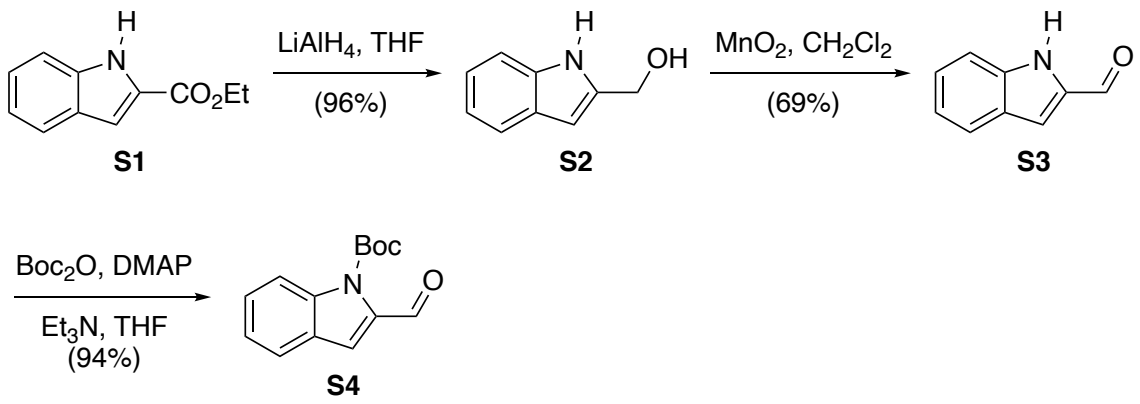

As shown in Scheme S1, tert-butyl 2-formyl-1H-indole-1-carboxylate (S4), which was used to construct imines 8a and 9a, was synthesized in three steps from ethyl $1 H$-indole-2-carboxylate (S1). Even though intermediate $1 H$-indole-2-carbaldehyde is commercially available, the relative high price of this aldehyde made the three-step process more economical. Specifically, the ethyl ester in $\mathbf{S 1}$ was reduced exhaustively with lithium aluminum hydride in tetrahydrofuran to form (1H-indol-2-yl)methanol (S2) in 96\% isolated yield. Manganese dioxide-mediated oxidation of alcohol S2 afforded aldehyde S3 in 69\% yield. Finally, Bocprotection of the indole nitrogen was achieved in 94\% yield following standard conditions.

(1H-Indol-2-yl)methanol (S2) ${ }^{1}$ : To a stirred solution of ethyl 1H-indole-2- carboxylate S1 (10.06 g, $\left.53.27 \mathrm{mmol}\right)$ and dry THF $(266 \mathrm{~mL})$ in a flame-dried round bottom flask under Ar atmosphere at $0{ }^{\circ} \mathrm{C}$ was added protionwise $\mathrm{LiAlH}_{4}(2.38 \mathrm{~g}, 62.74 \mathrm{mmol})$, and the resulting mixture was stirred under Ar at $0{ }^{\circ} \mathrm{C}$ for $5 \mathrm{~h}$. The reaction was then quenched at $0{ }^{\circ} \mathrm{C}$ with $\mathrm{H}_{2} \mathrm{O}(2.3 \mathrm{~mL})$, followed by addition of $15 \%$ aq $\mathrm{NaOH}(2.3 \mathrm{~mL})$ and an additional portion of $\mathrm{H}_{2} \mathrm{O}(7 \mathrm{~mL})$. The resulting mixture was stirred under Ar for $3 \mathrm{~h}$, and then filtered through Celite. The filtrate was concentrated by rotary evaporation and the resulting crude product was purified by flash chromatography $\left(1 \% \mathrm{Et}_{3} \mathrm{~N}\right.$ in 20\% EtOAc/PE) to give known alcohol S2 (7.49 g, $50.89 \mathrm{mmol}$, $96 \%)$ as a white solid. ${ }^{1} \mathrm{H}$ NMR $\left(400 \mathrm{MHz}, \mathrm{CDCl}_{3}\right) \delta 8.38(\mathrm{~s}, 1 \mathrm{H}), 7.62-7.56(\mathrm{~m}, 1 \mathrm{H}), 7.32-7.27(\mathrm{~m}, 1 \mathrm{H}), 7.20(\mathrm{ddd}, J=8.2$, 7.1, $1.3 \mathrm{~Hz}, 1 \mathrm{H}), 7.12(\mathrm{ddd}, J=8.1,5.5,1.1 \mathrm{~Hz}, 1 \mathrm{H}), 6.39(\mathrm{dd}, J=2.1,0.8 \mathrm{~Hz}, 1 \mathrm{H}), 4.75(\mathrm{~s}, 2 \mathrm{H}), 2.32(\mathrm{~s}, 1 \mathrm{H})$.

1H-Indole-2-carbaldehyde (S3) ${ }^{1}$ : To a solution of $\mathbf{S 2}(7.49 \mathrm{~g}, 50.9 \mathrm{mmol})$ in $\mathrm{CH}_{2} \mathrm{Cl}_{2}(510 \mathrm{~mL})$ was added portionwise at $\mathrm{rt}$ $\mathrm{MnO}_{2}(53.1 \mathrm{~g}, 61.1 \mathrm{mmol})$. The resulting slurry was stirred at rt open to air for $12 \mathrm{~h}$, after which, the resulting mixture was filtered through Celite. The filtrate was concentrated by rotary evaporation and the residue was purified by flash chromatography (1\% Et $3 \mathrm{~N}$ in 10\% EtOAc/PE) to give known aldehyde $\mathbf{S 3}(5.1 \mathrm{~g}, 35.13 \mathrm{mmol}, 69 \%)$ as a white solid. ${ }^{1} \mathrm{H}$ NMR $\left(400 \mathrm{MHz}, \mathrm{CDCl}_{3}\right) \delta 9.85(\mathrm{~s}, 1 \mathrm{H}), 9.20(\mathrm{~s}, 1 \mathrm{H}), 7.75(\mathrm{dd}, J=8.1,0.8 \mathrm{~Hz}, 1 \mathrm{H}), 7.46(\mathrm{dd}, J=8.4,0.9 \mathrm{~Hz}, 1 \mathrm{H}), 7.40(\mathrm{ddd}, J=$ $8.3,6.8,1.1 \mathrm{~Hz}, 1 \mathrm{H}), 7.29(\mathrm{dd}, J=2.1,0.9 \mathrm{~Hz}, 1 \mathrm{H}), 7.19(\mathrm{ddd}, J=8.0,6.9,1.1 \mathrm{~Hz}, 1 \mathrm{H})$.

tert-Butyl 2-formyl-1H-indole-1-carboxylate (S4) ${ }^{2}$ : To a stirred solution of S3 (1.0 g, $\left.6.9 \mathrm{mmol}\right)$, DMAP (84.3 mg, 0.69 mmol), and $\mathrm{Et}_{3} \mathrm{~N}(0.838 \mathrm{~g}, 8.28 \mathrm{mmol})$ in THF $(20 \mathrm{~mL})$ at $0{ }^{\circ} \mathrm{C}$ was added $(\mathrm{Boc})_{2} \mathrm{O}(1.8 \mathrm{~g}, 8.28 \mathrm{mmol})$. The reaction was allowed to reach $\mathrm{rt}$ and stirred at that temperature for $5 \mathrm{~h}$. Concentration by rotary evaporation and purification by flash chromatography $\left(1 \% \mathrm{Et}_{3} \mathrm{~N}\right.$ in $\left.10 \% \mathrm{EtOAc} / \mathrm{PE}\right)$ afforded known carbamate $\mathbf{S 4}(1.59 \mathrm{~g}, 6,48 \mathrm{mmol}, 94 \%)$ as a white solid. ${ }^{1} \mathrm{H} \mathrm{NMR}(400 \mathrm{MHz}$, $\left.\mathrm{CDCl}_{3}\right) \delta 10.41(\mathrm{~s}, 1 \mathrm{H}), 8.15(\mathrm{dd}, J=8.6,0.7 \mathrm{~Hz}, 1 \mathrm{H}), 7.64(\mathrm{~d}, J=7.9 \mathrm{~Hz}, 1 \mathrm{H}), 7.46(\mathrm{ddd}, J=8.5,7.2,1.2 \mathrm{~Hz}, 1 \mathrm{H}), 7.40(\mathrm{~s}$, $1 \mathrm{H}), 7.35-7.09(\mathrm{~m}, 1 \mathrm{H}), 1.71(\mathrm{~s}, 9 \mathrm{H})$.

\section{- Synthesis of tert-Butyl 3-Chloro-2-formyl-1H-indole-1-carboxylate}

\section{Scheme S2. Synthesis of tert-Butyl 2-Formyl-1H-indole-1-carboxylate (S6)}

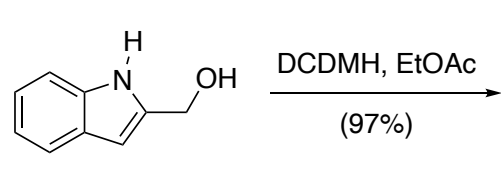

S2

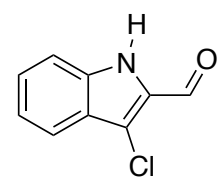

S5

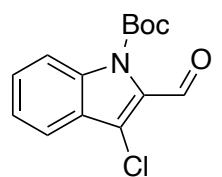

S6

As shown in Scheme S2, tert-butyl 3-chloro-2-formyl-1H-indole-1-carboxylate (S6), which was used to construct imines $\mathbf{8 b}$ and $\mathbf{9 b}$, was synthesized in two steps from (1H-indol-2-yl)methanol (S2). Specifically, 
concomitant chlorination at C-3 and oxidation of the alcohol with 1,3-dichloro-5,5-dimethylhydantoin (DCDMH), afforded aldehyde S5 in 97\% isolated yield. Boc-protection of the indole nitrogen was achieved in 98\% yield following standard conditions.

3-Chloro-1H-indole-2-carbaldehyde (S5) ${ }^{3}$ : To a stirred solution of $\mathbf{S 2}(1.03 \mathrm{~g}, 6.99 \mathrm{mmol})$ in EtOAc (300 $\left.\mathrm{mL}\right)$ at $\mathrm{rt}$ was added portion-wise DCDMH (1.515 g, $7.69 \mathrm{mmol})$. The reaction was stirred at $\mathrm{rt}$ for $12 \mathrm{~h}$, after which, rotary evaporation was used to remove solvent and the resulting residue was purified by flash chromatography ( $1 \% \mathrm{Et}_{3} \mathrm{~N}$ in $\left.10 \% \mathrm{EtOAc} / \mathrm{PE}\right)$ to give known chlorinated indole aldehyde $\mathbf{S 5}(1.22 \mathrm{~g}, 6.81 \mathrm{mmol}, 97 \%)$ as a yellow solid. ${ }^{1} \mathrm{H}$ NMR $\left(400 \mathrm{MHz}, \mathrm{CDCl}_{3}\right) \delta 10.06(\mathrm{~s}, 1 \mathrm{H}), 9.02$ (s, 1H), $7.76(\mathrm{~d}, J=8.2 \mathrm{~Hz}, 1 \mathrm{H}), 7.50-7.39(\mathrm{~m}, 2 \mathrm{H}), 7.25(\mathrm{~m}, 1 \mathrm{H})$.

tert-Butyl 3-chloro-2-formyl-1H-indole-1-carboxylate (S6): To a stirred solution of S5 (4.03 g, 22.46 mmol), DMAP (274.4 $\mathrm{mg}, 2.246 \mathrm{mmol})$, and $\mathrm{Et}_{3} \mathrm{~N}(2.73 \mathrm{~g}, 26.96 \mathrm{mmol})$ in THF $(85 \mathrm{~mL})$ at $0{ }^{\circ} \mathrm{C}$ was added $(\mathrm{Boc})_{2} \mathrm{O}(6.37 \mathrm{~g}, 29.20 \mathrm{mmol}, 1.3 \mathrm{~mL})$. The solution was allowed to warm to rt and stirred at that temperature for $5 \mathrm{~h}$. The reaction was quenched with $\mathrm{H}_{2} \mathrm{O}$, and extracted with EtOAc $(3 \times 60 \mathrm{~mL})$. The combined organic layer was wash with brine, dried $\left(\mathrm{Na}_{2} \mathrm{SO}_{4}\right)$, and concentrated by rotary evaporation. The result crude product was purified by flash chromatography $\left(1 \% \mathrm{Et}_{3} \mathrm{~N}\right.$ in $\left.10 \% \mathrm{EtOAc} / \mathrm{PE}\right)$ to afford known carbamate $\mathbf{S 6}(6.12 \mathrm{~g}, 21.88 \mathrm{mmol}, 98 \%)$ as a white solid. ${ }^{1} \mathrm{H}$ NMR $\left(400 \mathrm{MHz}, \mathrm{CDCl}_{3}\right) \delta 10.32(\mathrm{~s}, 1 \mathrm{H}), 8.23-8.03(\mathrm{~m}, 1 \mathrm{H})$, 7.70 (ddd, $J=7.9,1.1,0.7 \mathrm{~Hz}, 1 \mathrm{H}), 7.52$ (ddd, $J=8.5,7.2,1.3 \mathrm{~Hz}, 1 \mathrm{H}), 7.35$ (ddd, $J=8.0,7.2,0.8 \mathrm{~Hz}, 1 \mathrm{H}), 1.68(\mathrm{~s}, 9 \mathrm{H})$.

\section{- Synthesis of 3-(2-Hydroxyethyl)-1H-indole-2-carbaldehyde}

\section{Scheme S3. Synthesis of 3-(2-Hydroxyethyl)-1H-indole-2-carbaldehyde (S8)}

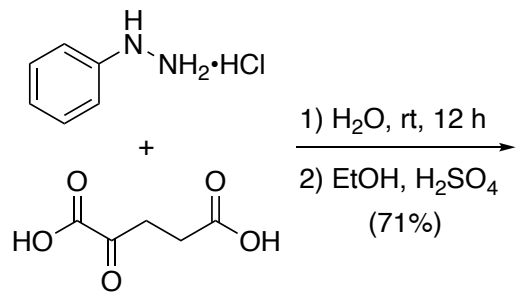

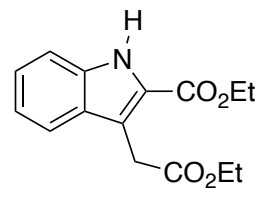

S7

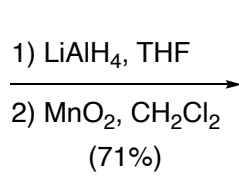

As shown in Scheme S3, 3-(2-hydroxyethyl)- 1H-indole-1-carbaldehyde (S8), which was used to construct imines 8d, was synthesized in two steps. Specifically, Fischer indole synthesis between phenylhydrazine hydrochloride and oxobutanedioic acid, followed by acid-mediated esterification provided ethyl ester $\mathbf{S 7}$ in $71 \%$ yield. Exhaustive reduction of both esters with lithium aluminum hydride, followed immediately by selective oxidation of the benzylic alcohol with $\mathrm{MnO}_{2}$ generated the desired aldehyde $\mathbf{S 8}$ in $71 \%$ yield over the two steps.

Ethyl 3-(2-ethoxy-2-oxoethyl)-1H-indole-2-carboxylate (S7) ${ }^{4}$ : A solution of phenylhydrazine hydrochloride (14.5 g, $\left.0.1 \mathrm{~mol}\right)$ and oxobutanedioic Acid $(14.6 \mathrm{~g}, 0.1 \mathrm{mmol})$ in $\mathrm{H}_{2} \mathrm{O}(100 \mathrm{~mL})$ was stirred at $\mathrm{rt}$ for $12 \mathrm{~h}$ resulting in the precipitation of a yellow solid from the reaction mixture. The resulting yellow solid was isolated by filtration, air dried, and dissolved in EtOH (150 $\mathrm{mL})$. To the stirred ethanolic solution at $\mathrm{rt}$ was slowly added dropwise concentrated $\mathrm{H}_{2} \mathrm{SO}_{4}(25 \mathrm{~mL})$. The stirred reaction mixture was heated to reflux for $4 \mathrm{~h}$, then cooled to $0{ }^{\circ} \mathrm{C}$, quenched with $15 \%$ aq NaOH, and extracted with EtOAc $(3 \times 120$ $\mathrm{mL}$ ). The combined organic layer was wash with brine, dried $\left(\mathrm{Na}_{2} \mathrm{SO}_{4}\right)$, concentrated by rotary evaporation, and purified by flash chromatography $\left(1 \% \mathrm{Et}_{3} \mathrm{~N}\right.$ in $\left.20 \% \mathrm{EtOAc} / \mathrm{PE}\right)$ to give known diester $\mathbf{S 7}(20.4218 \mathrm{~g}, 70.63 \mathrm{mmol}, 71 \%)$ as a white solid. ${ }^{1} \mathrm{H}$ NMR $\left(400 \mathrm{MHz}, \mathrm{CDCl}_{3}\right) \delta 8.96(\mathrm{~s}, 1 \mathrm{H}), 7.66(\mathrm{~d}, J=8.1 \mathrm{~Hz}, 1 \mathrm{H}), 7.35(\mathrm{dtd}, J=9.4,8.3,1.0 \mathrm{~Hz}, 2 \mathrm{H}), 7.16(\mathrm{ddd}, J=8.0$, $6.9,1.1 \mathrm{~Hz}, 1 \mathrm{H}), 4.40(\mathrm{dt}, J=9.0,6.2 \mathrm{~Hz}, 2 \mathrm{H}), 4.17(\mathrm{p}, J=7.2 \mathrm{~Hz}, 4 \mathrm{H}), 1.41(\mathrm{td}, J=7.1,1.2 \mathrm{~Hz}, 3 \mathrm{H}), 1.25(\mathrm{t}, J=7.1 \mathrm{~Hz}, 3 \mathrm{H})$; ${ }^{13} \mathrm{C} \mathrm{NMR}\left(101 \mathrm{MHz}, \mathrm{CDCl}_{3}\right) \delta$ 171.3, 162.0, 135.7, 127.9, 125.6, 124.4, 120.5, 120.5, 115.8, 111.9, 61.0, 60.8, 30.7, 14.3, 14.2.

3-(2-Hydroxyethyl)-1H-indole-2-carbaldehyde (S8) ${ }^{5}$ : To a stirred solution of diester S7 (15.265 g, $\left.52.80 \mathrm{mmol}\right)$ and dry THF $(500 \mathrm{~mL})$ under $\mathrm{Ar}$ atmosphere at $0^{\circ} \mathrm{C}$ was added portion-wise $\mathrm{LiAlH}_{4}(5.0094 \mathrm{~g}, 132 \mathrm{mmol})$. The resulting mixture was stirred at $0{ }^{\circ} \mathrm{C}$ under $\mathrm{Ar}$ for $5 \mathrm{~h}$, after which, the reaction was quenched at $0{ }^{\circ} \mathrm{C}$ by sequential addition of $\mathrm{H}_{2} \mathrm{O}(5 \mathrm{~mL}), 15 \%$ aq $\mathrm{NaOH}$ $(5 \mathrm{~mL})$, and more $\mathrm{H}_{2} \mathrm{O}(15 \mathrm{~mL})$. This mixture was stirred under $\mathrm{Ar}$ for $3 \mathrm{~h}$, and then filtered through Celite. Rotary evaporation was used to remove solvent and the crude product was immediately dissolved in $\mathrm{CH}_{2} \mathrm{Cl}_{2}(510 \mathrm{~mL})$. To the resulting solution at rt was added portion-wise $\mathrm{MnO}_{2}(45.9 \mathrm{~g}, 528 \mathrm{mmol})$, and the reaction was allowed to stir at $\mathrm{rt}$ for $12 \mathrm{~h}$. The resulting slurry was filtered through Celite, concentrated by rotary evaporation, and purified by flash chromatography ( $1 \% \mathrm{Et}_{3} \mathrm{~N}$ in $40 \%$ EtOAc/PE) to afford aldehyde $\mathbf{S 8}(7.0734 \mathrm{~g}, 37.38 \mathrm{mmol}, 71 \%)$ as a white solid. ${ }^{1} \mathrm{H}$ NMR $\left(400 \mathrm{MHz}, \mathrm{CDCl}_{3}\right) \delta 11.64(\mathrm{~s}, 1 \mathrm{H})$, $9.99(\mathrm{~s}, 1 \mathrm{H}), 7.77-7.72(\mathrm{~m}, 1 \mathrm{H}), 7.42-7.39(\mathrm{~m}, 1 \mathrm{H}), 7.31(\mathrm{ddd}, J=8.2,6.9,1.1 \mathrm{~Hz}, 1 \mathrm{H}), 7.08(\mathrm{ddd}, J=8.0,6.9,1.0 \mathrm{~Hz}, 1 \mathrm{H})$, 
$4.78(\mathrm{t}, J=5.5 \mathrm{~Hz}, 1 \mathrm{H}), 3.66(\mathrm{q}, J=6.5 \mathrm{~Hz}, 2 \mathrm{H}), 3.22(\mathrm{t}, J=6.6 \mathrm{~Hz}, 2 \mathrm{H}) .{ }^{13} \mathrm{C} \mathrm{NMR}(101 \mathrm{MHz}, \mathrm{CDCl} 3) \delta 187.3,142.9,138.3$, $132.2,131.6,130.4,126.5,124.9,117.9,66.9,32.3$.

\section{- Conversion of 11a into 10a via Olefin Metathesis}

As mentioned in the main text, the Ni-catalyzed asymmetric decarboxylative allylation (DcA) of allyl ester 9a to homoallylic imine 11a proceeded in significantly higher yield and improved enantiomeric ratio in comparison to the DcA of crotonate 8a to 10a. Accordingly, we sought to identify conditions to readily convert 11a into the desired 10a via olefin metathesis. Preliminary studies using the Grubbs' second-generation catalyst (Grubbs II) demonstrated that the transformation is feasible, but significant optimization is required to improve the isolated yield (currently $29 \%$, Scheme S4).

\section{Scheme S4. Conversion of 11a into 10a via Olefin Metathesis}<smiles>C=CCC(N=C(c1ccccc1)c1ccccc1)c1cc2ccccc2n1C(=O)OCc1ccccc1</smiles>

$( \pm)-11 a$<smiles>CC(=O)/C=C/CC(N=C(c1ccccc1)c1ccccc1)c1cc2ccccc2n1C(=O)OCc1ccccc1</smiles>

$( \pm)-10 a$

Experimental Conditions: To a flame-dried high-pressure glass vessel with a magnetic stir bar was added imine $11 \mathrm{a}$ ( $316 \mathrm{mg}$, $0.702 \mathrm{mmol})$ and methyl acrylate $(562 \mathrm{mg}, 7.02 \mathrm{mmol})$. The flask was degassed with three consecutive vacuum/argon-fill cycles and entered into a inert-environment glove box. To the solution was added Grubbs II $(10 \mathrm{~mol} \%)$ in glove box followed by dry $\mathrm{CH}_{2} \mathrm{Cl}_{2}(7 \mathrm{~mL})$ with syringe. The resulting solution was stirred $90{ }^{\circ} \mathrm{C}$ for 2 days, after which the solvent was removed by rotary evaporation and the residue was purified by flash chromatography $\left(1 \% \mathrm{Et}_{3} \mathrm{~N}\right.$ in $\left.5 \% \mathrm{EtOAc} / \mathrm{PE}\right)$ to afford imine 10a (103 mg, $0.20 \mathrm{mmol}, 29 \%$ ) as a thick colorless oil.

\section{- Thermal IMDA of $( \pm)-4 a$ : Synthesis of $( \pm)-$ endo-14a and $( \pm)$-exo-14a}

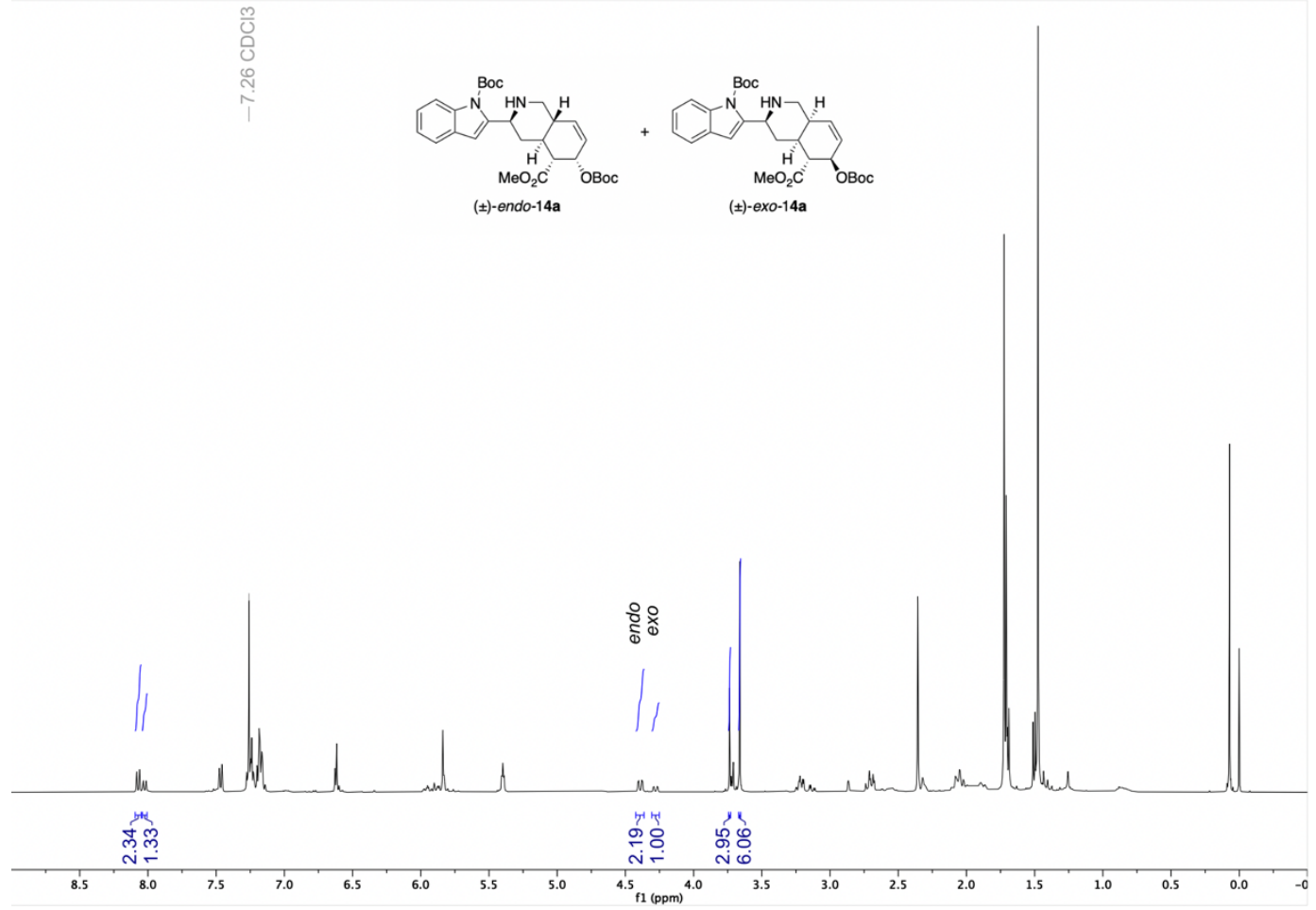

Figure S1. ${ }^{1}$ H NMR Spectrum of Thermal IMDA Cycloaddition of ( \pm )-4a 
Experimental Conditions: A solution of $4 \mathbf{a}(16 \mathrm{mg}, 0.03 \mathrm{mmol})$ in dry toluene $(2 \mathrm{~mL}, 15 \mathrm{mM})$ under $\mathrm{Ar}$ was heated to $70{ }^{\circ} \mathrm{C}$ and stirred at that temperature for $3 \mathrm{~d}$, after which the solvent was removed by rotary evaporation. Analysis of the resulting residue by ${ }^{1} \mathrm{H}$ NMR spectroscopy $\left(\mathrm{CDCl}_{3}\right)$ indicated that the ratio of cycloaddition diastereomers was $\sim 2: 1$ in favor of the endo product (Figure S1). The two products could be separated by exhaustive flash chromatography (100\% EtOAc).

( \pm )-endo-14a: $\mathrm{HRMS}$ calcd for $\mathrm{C}_{29} \mathrm{H}_{39} \mathrm{~N}_{2} \mathrm{O}_{7}{ }^{+}[\mathrm{M}+\mathrm{H}]^{+}$527.2752, found 527.2721.

( \pm )-exo-14b: HRMS calcd for $\mathrm{C}_{29} \mathrm{H}_{39} \mathrm{~N}_{2} \mathrm{O}_{7}{ }^{+}[\mathrm{M}+\mathrm{H}]^{+}$527.2752, found 527.2730.

\section{- Alternate Synthesis of $( \pm)-16 a$ from $( \pm)-4 a^{\prime}$}

An alternate synthesis of indole $( \pm)$-16a in which the $N$-Boc protecting group is removed prior to reductive amination and Sc(OTf) 3 -mediated IMDA cycloaddition is outlined in Scheme S5. Initially, the Boc carbamate in amine $( \pm)$-13a could be removed by treatment with TFA, affording free indole $\mathbf{S 9}$ in $77 \%$ isolated yield. Reductive amination between imine $\mathbf{S 9}$ and aldehyde $\mathbf{5}$ generated IMDA precursor $( \pm)-\mathbf{4 a}$ ' in $47 \%$ isolated yield. Finally, treatment of a solution of $( \pm)-\mathbf{4 a}$ ' in $\mathrm{MeCN}$ at rt with 4 equiv of $\mathrm{Sc}(\mathrm{OTf})_{3}$ initiated the desired cycloaddition to provide fully-deprotected cycloadduct $( \pm)-\mathbf{1 6 a}$ in $65 \%$ yield after chromatographic purification. Following this strategy, IMDA cycloadduct 16a was synthesized in three steps and $24 \%$ total yield, which is inferior to the $33 \%$ total yield achieved by performing the cycloaddition prior to removal of the indole Boc carbamate (see Scheme 3 in the Main Text).

\section{Scheme S5. Synthesis of ( \pm )-4a' and IMDA Cycloaddition to $( \pm)-16 a$}

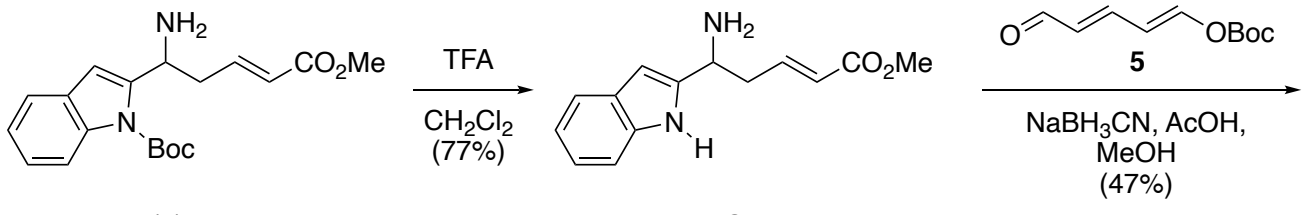

$( \pm)-13 a$

S9

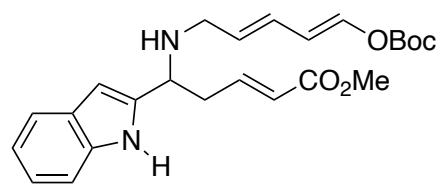

$( \pm)-4 a$

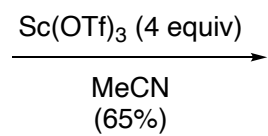

$(65 \%)$

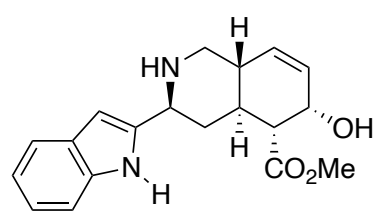

$( \pm)-16 a$

Methyl (E)-5-amino-5-(1H-indol-2-yl)pent-2-enoate (S9): To a stirred solution of amine 13a (682 $\mathrm{mg}, 1.8 \mathrm{mmol})$ in $\mathrm{CH}_{2} \mathrm{Cl}_{2}$ $(20 \mathrm{~mL})$ at $\mathrm{rt}$ was added in TFA $(4 \mathrm{~mL})$. The mixture was stirred at $\mathrm{rt}$ for $12 \mathrm{~h}$, then quenched with sat aq $\mathrm{NaHCO}_{3}$ and extracted with EtOAc $(3 \times 25 \mathrm{~mL})$. The combined organic layer was washed with brine, dried $\left(\mathrm{Na}_{2} \mathrm{SO}_{4}\right)$, concentrated by rotary evaporation, and purified by flash chromatography ( $1 \% \mathrm{Et}_{3} \mathrm{~N}$ in $\left.100 \% \mathrm{EtOAc}\right)$ to give the amine $\mathbf{S 9}$ (339 $\left.\mathrm{mg}, 1.39 \mathrm{mmol}, 77 \%\right)$ as a thick yellow oil. $\mathrm{R}_{f}=0.19$ (1\% Et $3 \mathrm{~N}$ in 50\% EtOAc/PE). IR (thin film) $v 3239.3,2945.5,2036.8,1735.9,1639.5,1008.8,798.5$, 744.5, 700.2, $561.3{ }^{1} \mathrm{H}$ NMR (400 MHz, $\left.\mathrm{CDCl}_{3}\right) \delta 8.72(\mathrm{~s}, 1 \mathrm{H}), 7.56(\mathrm{~d}, J=7.8 \mathrm{~Hz}, 1 \mathrm{H}), 7.35(\mathrm{~d}, J=8.0 \mathrm{~Hz}, 1 \mathrm{H}), 7.20-7.12$ (m, 1H), $7.12-7.05(\mathrm{~m}, 1 \mathrm{H}), 7.01-6.91(\mathrm{~m}, 1 \mathrm{H}), 6.36-6.32(\mathrm{~m}, 1 \mathrm{H}), 5.95(\mathrm{dt}, J=15.6,1.3 \mathrm{~Hz}, 1 \mathrm{H}), 4.34(\mathrm{dd}, J=7.6,5.3$ $\mathrm{Hz}, 1 \mathrm{H}), 3.72(\mathrm{~d}, J=3.9 \mathrm{~Hz}, 3 \mathrm{H}), 2.79$ (dddd, $J=13.9,6.8,5.3,1.5 \mathrm{~Hz}, 1 \mathrm{H}), 2.62(\mathrm{dtd}, J=9.1,8.0,1.2 \mathrm{~Hz}, 1 \mathrm{H}) ;{ }^{13} \mathrm{C}$ NMR $\left(101 \mathrm{MHz}, \mathrm{CDCl}_{3}\right) \delta 166.5,144.8,141.1,135.6,128.3,124.1,121.7,120.3,119.7,110.8,98.7,51.6,48.9,41.1$. HRMS calcd for $\mathrm{C}_{14} \mathrm{H}_{17} \mathrm{~N}_{2} \mathrm{O}_{2}{ }^{+}[\mathrm{M}+\mathrm{H}]^{+}$245.1285, found 245.1288.

Methyl-(E)-5-(((2E,4E)-5-((tert-butoxycarbonyl)oxy)penta-2,4-dien-1-yl)amino)-5-(1H-indol-2-yl)pent-2-enoate (4a'): A slurry of amine 4a' $(74 \mathrm{mg}, 0.3 \mathrm{mmol})$, aldehyde 5 (59 mg, $0.3 \mathrm{mmol}),{ }^{6}$ and $4 \AA$ mol sieves $(2 \mathrm{~g})$ in dry THF $(16 \mathrm{~mL})$ was stirred under $\mathrm{Ar}$ atmosphere at $-20^{\circ} \mathrm{C}$ for $30 \mathrm{~min}$. The reaction was warmed to $\mathrm{rt}$ and a solution of $\mathrm{NaBH}_{3} \mathrm{CN}(113 \mathrm{mg}, 1.8$ $\mathrm{mmol}$ ) in $\mathrm{MeOH}$ was added in the system. After $30 \mathrm{~min}$, a solution of acetic acid (54 mg, $0.9 \mathrm{mmol})$ in $\mathrm{MeOH}$ was added and the reaction was stirred for an additional $5 \mathrm{~h}$. Finally, the resulting mixture was filtered through Celite (THF wash) and the filtrate was concentrated by rotary evaporation and purified by flash chromatography ( $1 \% \mathrm{Et}_{3} \mathrm{~N}$ in $\left.50 \% \mathrm{EtOAc} / \mathrm{PE}\right)$ to afford the amine $4 \mathbf{a}^{\prime}(60 \mathrm{mg}, 0.14 \mathrm{mmol}, 47 \%)$ as a thick yellow oil. $\mathrm{R}_{f}=0.29\left(1 \% \mathrm{Et}_{3} \mathrm{~N}\right.$ in $\left.50 \% \mathrm{EtOAc} / \mathrm{PE}\right)$. IR (thin film) $v 3408.2$, 2949.1,1739.8, 1543.1, 1369.5, 1280.7, 1161.2, 1084.0, 979.8, 844.8, 744.5. ${ }^{1} \mathrm{H}$ NMR $\left(400 \mathrm{MHz}, \mathrm{CDCl}_{3}\right) \delta 8.58(\mathrm{~s}, 1 \mathrm{H}), 7.56$ $(\mathrm{d}, J=7.9 \mathrm{~Hz}, 1 \mathrm{H}), 7.35(\mathrm{dd}, J=8.0,0.8 \mathrm{~Hz}, 1 \mathrm{H}), 7.19-7.05(\mathrm{~m}, 3 \mathrm{H}), 6.98-6.86(\mathrm{~m}, 1 \mathrm{H}), 6.36(\mathrm{~d}, J=1.7 \mathrm{~Hz}, 1 \mathrm{H}), 6.09-$ 
$5.81(\mathrm{~m}, 3 \mathrm{H}), 5.73-5.59(\mathrm{~m}, 1 \mathrm{H}), 4.09(\mathrm{t}, J=6.5 \mathrm{~Hz}, 1 \mathrm{H}), 3.72(\mathrm{~s}, 3 \mathrm{H}), 3.16(\mathrm{qd}, J=14.5,6.9 \mathrm{~Hz}, 2 \mathrm{H}), 2.77-2.57(\mathrm{~m}, 2 \mathrm{H})$, 1.52 (s, 9H); ${ }^{13} \mathrm{C}$ NMR $\left(101 \mathrm{MHz}, \mathrm{CDCl}_{3}\right) \delta 166.5,150.6,144.7,139.4,139.4,135.7,130.8,128.4,126.4,123.9,121.6,120.2$, 119.7, 114.3, 110.9, 100.5, 83.7, 54.8, 51.6, 48.9, 39.5, 27.6. HRMS calcd for $\mathrm{C}_{24} \mathrm{H}_{31} \mathrm{~N}_{2} \mathrm{O}_{5}^{+}[\mathrm{M}+\mathrm{H}]^{+} 427.2227$, found 427.2226.

rac-Methyl (3s,4aS,5R,6S,8aR)-6-hydroxy-3-(1H-indol-2-yl)-1,2,3,4,4a,5,6,8a-octahydro -isoquinoline-5-carboxylate (16a): To a flame-dried flask was combined under Ar triene ( \pm )-4a' $(188 \mathrm{mg}, 0.44 \mathrm{mmol}), \mathrm{Sc}(\mathrm{OTf})_{3}(871 \mathrm{mg}, 1,76 \mathrm{mmol})$, and dry $\mathrm{MeCN}(147 \mathrm{~mL})$. The resulting solution was stirred under Ar at $\mathrm{rt}$ for $7 \mathrm{~h}$. Finally, the reaction was quenched with sat aq $\mathrm{NaHCO}_{3}$ and extracted with EtOAc $(3 \times 100 \mathrm{~mL})$. The combined organic layer was washed with brine, dried $\left(\mathrm{Na}_{2} \mathrm{SO}_{4}\right)$, concentrated by rotary evaporation, and purified by flash chromatography $\left(10 \% \mathrm{MeOH} / \mathrm{CH}_{2} \mathrm{Cl}_{2}\right)$ to afford the endo-IMDA cycloadduct $( \pm)-16 a(121 \mathrm{mg}, 0.37 \mathrm{mmol}, 65 \%)$ as a thick yellow oil and spectroscopically identical to the product generated by deprotection of Boc carbamate 15a.

\section{- Synthesis of $( \pm)-4 b$}

As noted in the main text, treatment of 3-H indole $( \pm)-\mathbf{1 0 a}$ with a combination of aqueous $\mathrm{HCl}$ in ethyl acetate resulted in selective hydrolysis of the benzophenone imine without impacting the Boc protection on the indole nitrogen. This was not the case, however, with the 3-Cl analogue $( \pm)-\mathbf{1 0 b}$. Specifically, when 10b

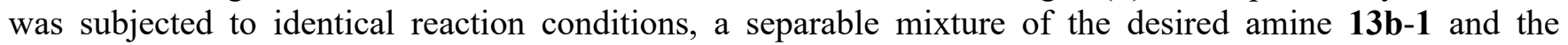
corresponding carbamate 13b-2, in which the Boc group migrated from the indole nitrogen to the more accessible primary amine, was isolated in a combined 78\% yield (Scheme S6). Since the other 3-substituted indole 13c did not demonstrate a similar carbamate migration (see below, Scheme S7), it is currently unclear what is unique about 3-chloro-substituted $\mathbf{1 3 b}$ to make Boc-migration so favorable. Our previous studies involving free indole $( \pm)-\mathbf{4 a}$ ' (see above, Scheme S5) demonstrated that protection of the indole nitrogen was not necessary to achieve acceptable yield and stereoselectivity for the $\mathrm{Sc}(\mathrm{OTf})_{3}$-mediated IMDA cycloaddition. Accordingly, fully deprotected amine $\mathbf{S 1 0}$ was generated by treatment of the mixture of carbamates $\mathbf{1 3 b - 1}$ and 13b-2 with TFA (73\%) and advanced to $( \pm)-4 \mathbf{b}$ in $67 \%$ by reductive amination with aldehyde 5 .

\section{Scheme S6. Synthesis of $( \pm)-4 b$}

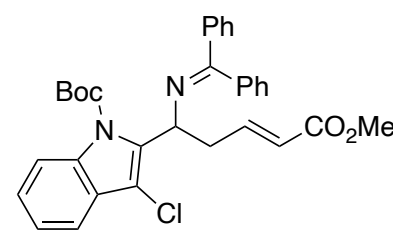

$( \pm)-10 b$

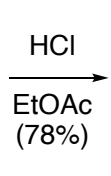

$(78 \%)$

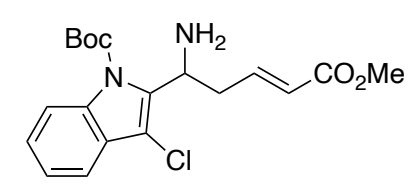

$( \pm)-13 b-1$

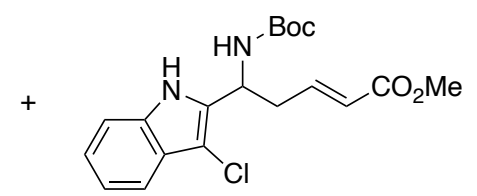

(士)-13b-2

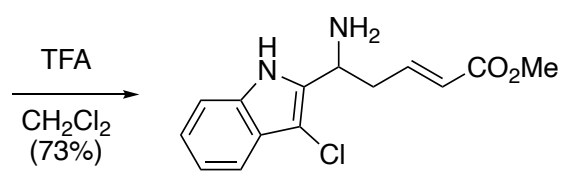

(士)-S10

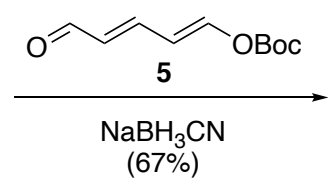

(67\%)

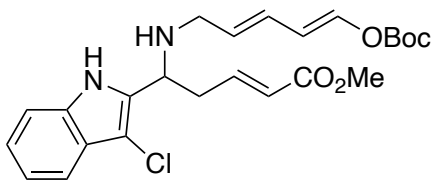

$( \pm)-4 b$

tert-Butyl-(E)-2-(1-amino-5-methoxy-5-oxopent-3-en-1-yl)-3-chloro-1H-indole-1-carboxylate (13b): To a stirred solution of $10 b(940 \mathrm{mg}, 1.73 \mathrm{mmol})$ in EtOAc $(75 \mathrm{~mL})$ under Ar atmosphere at $0{ }^{\circ} \mathrm{C}$ was slowly added dropwise $35 \%$ aq $\mathrm{HCl}(1.1 \mathrm{~mL})$, after which the solution was warmed to rt and stirred at that temperature for $8 \mathrm{~h}$. The reaction mixture was quenched with sat aq $\mathrm{NaHCO}_{3}$ and extracted with EtOAc $(3 \times 25 \mathrm{~mL})$. The combined organic layer was washed with brine, dried $\left(\mathrm{Na}_{2} \mathrm{SO}_{4}\right)$, concentrated by rotary evaporation., and purified by flash chromatography $\left(1 \% \mathrm{Et}_{3} \mathrm{~N}\right.$ in $\left.20 \% \rightarrow 50 \% \mathrm{EtOAc} / \mathrm{PE}\right)$ to afford a mixture of carbamates 13b-1 and 13b-2 $(510 \mathrm{mg}, 1.35 \mathrm{mmol}, \mathbf{7 8 \%}) \mathbf{1 3 b}-\mathbf{1}:{ }^{1} \mathrm{H} \mathrm{NMR}\left(400 \mathrm{MHz}, \mathrm{CDCl}_{3}\right) \delta 7.96(\mathrm{~d}, J=8.1 \mathrm{~Hz}$, $1 \mathrm{H}), 7.56-7.49(\mathrm{~m}, 1 \mathrm{H}), 7.37-7.19(\mathrm{~m}, 2 \mathrm{H}), 7.00-6.91(\mathrm{~m}, 1 \mathrm{H}), 5.89(\mathrm{~d}, J=15.6 \mathrm{~Hz}, 1 \mathrm{H}), 4.82(\mathrm{t}, J=7.5 \mathrm{~Hz}, 1 \mathrm{H}), 3.67(\mathrm{~s}$, $3 \mathrm{H}), 2.98-2.80(\mathrm{~m}, 2 \mathrm{H}), 2.19(\mathrm{~s}, 2 \mathrm{H}), 1.70(\mathrm{~s}, 9 \mathrm{H}) . \mathbf{1 3 b}-2 \cdot{ }^{1} \mathrm{H}$ NMR $\left(400 \mathrm{MHz}, \mathrm{CDCl}_{3}\right) \delta 9.28(\mathrm{~s}, 1 \mathrm{H}), 7.55(\mathrm{~d}, J=7.8 \mathrm{~Hz}$ $1 \mathrm{H}), 7.29(\mathrm{~d}, J=8.0 \mathrm{~Hz}, 1 \mathrm{H}), 7.17(\mathrm{dtd}, J=14.7,7.1,1.2 \mathrm{~Hz}, 2 \mathrm{H}), 6.99-6.80(\mathrm{~m}, 1 \mathrm{H}), 5.91(\mathrm{~d}, J=15.6 \mathrm{~Hz}, 1 \mathrm{H}), 5.34(\mathrm{~s}, 1 \mathrm{H})$, $4.89(\mathrm{~s}, 1 \mathrm{H}), 3.70(\mathrm{~s}, 3 \mathrm{H}), 3.08(\mathrm{~s}, 1 \mathrm{H}), 2.84(\mathrm{~s}, 1 \mathrm{H}), 1.42(\mathrm{~s}, 9 \mathrm{H})$.

Methyl (E)-5-amino-5-(3-chloro-1H-indol-2-yl)pent-2-enoate (S10): To a stirred solution of 13b-1 and 13b-2 (1.707 g, 4.50 $\mathrm{mmol})$ in $\mathrm{CH}_{2} \mathrm{Cl}_{2}(50 \mathrm{~mL})$ at $\mathrm{rt}$ was added in TFA $(10 \mathrm{~mL})$ and the reaction was stirred at $\mathrm{rt}$ for $12 \mathrm{~h}$. The resulting mixture was 
quenched with sat aq $\mathrm{NaHCO}_{3}$ and extracted with EtOAc $(3 \times 35 \mathrm{~mL})$. The combined organic layer was washed with brine, dried $\left(\mathrm{Na}_{2} \mathrm{SO}_{4}\right)$, concentrated by rotary evaporation, and purified by flash chromatography (1\% $\left.\mathrm{Et}_{3} \mathrm{~N} / \mathrm{EtOAc}\right)$ to afford amine $\mathbf{S 1 0}$ (910 mg, $3.26 \mathrm{mmol}, 73 \%$ ) as a thick red oil. $\mathrm{R}_{\mathrm{f}}=0.24\left(1 \% \mathrm{Et}_{3} \mathrm{~N}\right.$ in 50\% EtOAc/PE). IR (thin film) v3356.1, 2949.2, 2364.7, 1716.6, 1654.9, 1442.7, 1332.8, 1276.8, 1207.4, 1041.5, 977.9, 840.9, 744.5. ${ }^{1} \mathrm{H}$ NMR (400 MHz, $\left.\mathrm{CDCl}_{3}\right) \delta 8.93(\mathrm{~s}, 1 \mathrm{H}), 7.55$ $(\mathrm{dd}, J=8.2,0.7 \mathrm{~Hz}, 1 \mathrm{H}), 7.39-7.26(\mathrm{~m}, 1 \mathrm{H}), 7.22-7.11(\mathrm{~m}, 2 \mathrm{H}), 6.98-6.88(\mathrm{~m}, 1 \mathrm{H}), 5.91(\mathrm{dt}, J=15.6,1.3 \mathrm{~Hz}, 1 \mathrm{H}), 4.60$ $(\mathrm{dd}, J=7.7,5.2 \mathrm{~Hz}, 1 \mathrm{H}), 3.70(\mathrm{~s}, 3 \mathrm{H}), 2.76-2.67(\mathrm{~m}, 1 \mathrm{H}), 2.62-2.53(\mathrm{~m}, 1 \mathrm{H}), 1.86(\mathrm{~s}, 2 \mathrm{H}) .{ }^{13} \mathrm{C} \mathrm{NMR}\left(101 \mathrm{MHz}, \mathrm{CDCl}_{3}\right) \delta$ 166.6, 144.4, 135.5, 133.7, 126.1, 124.2, 122.6, 120.3, 117.7, 111.3, 101.8, 51.6, 46.5, 39.9. HRMS calcd for $\mathrm{C}_{14} \mathrm{H}_{16} \mathrm{ClN}_{2} \mathrm{O}_{2}$ $[\mathrm{M}+\mathrm{H}]^{+}$279.0895, found 279.0896 .

Methyl-(E)-5-(((2E,4E)-5-((tert-butoxycarbonyl)oxy)penta-2,4-dien-1-yl)amino)-5-(3-chloro-1H-indol-2-yl)pent-2-enoate (4b): A slurry of amine 12b (262 mg, $0.94 \mathrm{mmol})$, aldehyde $5^{6}(186 \mathrm{mg}, 0.94 \mathrm{mmol})$, and $4 \AA$ mol seives $(8 \mathrm{~g})$ in dry THF (50 $\mathrm{mL}$ ) was stirred under $\mathrm{Ar}$ at $-20{ }^{\circ} \mathrm{C}$ for $30 \mathrm{~min}$. After warming to rt, a solution of $\mathrm{NaBH}_{3} \mathrm{CN}$ (354 mg, $\left.5.64 \mathrm{mmol}\right)$ in $\mathrm{MeOH}$ was added in the system by syringe. After another $30 \mathrm{~min}$, a solution of acetic acid (169.3 $\mathrm{mg}, 2.82 \mathrm{mmol})$ in $\mathrm{MeOH}$ was added in the reaction system, which was stirred for an additional $5 \mathrm{~h}$ at rt. The resulting mixture was filtered through Celite (washed with THF) and the filtrated was concentrated by rotary evaporation. The resulting residue was purified by flash chromatography $\left(1 \% \mathrm{Et}_{3} \mathrm{~N}\right.$ in $\left.50 \% \mathrm{EtOAc} / \mathrm{PE}\right)$ to afford the desired secondary amine $\mathbf{4 b}(290 \mathrm{mg}, 0.63 \mathrm{mmol}, 67 \%)$ as a viscous yellow oil. $\mathrm{R}_{\mathrm{f}}$ $=0.34\left(1 \% \mathrm{Et}_{3} \mathrm{~N}\right.$ in 50\% EtOAc/PE). IR (thin film) v 3404.4, 2927.9, 2850.8, 1739.8, 1371.4, 1282.7, 1163.1, 1082.1, 979.8, 848.7, 790.8, 742.6. ${ }^{1} \mathrm{H}$ NMR (400 MHz, $\left.\mathrm{CDCl}_{3}\right) \delta 8.66(\mathrm{~s}, 1 \mathrm{H}), 7.57(\mathrm{~d}, J=7.8 \mathrm{~Hz}, 1 \mathrm{H}), 7.33(\mathrm{~d}, J=8.0 \mathrm{~Hz}, 1 \mathrm{H}), 7.24-7.11$ $(\mathrm{m}, 3 \mathrm{H}), 6.96-6.87(\mathrm{~m}, 1 \mathrm{H}), 6.07-5.87(\mathrm{~m}, 3 \mathrm{H}), 5.68-5.59(\mathrm{~m}, 1 \mathrm{H}), 4.32(\mathrm{dd}, J=7.4,5.7 \mathrm{~Hz}, 1 \mathrm{H}), 3.72(\mathrm{~s}, 3 \mathrm{H}), 3.14(\mathrm{qd}$, $J=14.5,6.8 \mathrm{~Hz}, 2 \mathrm{H}), 2.75-2.55(\mathrm{~m}, 2 \mathrm{H}), 1.80(\mathrm{~s}, 2 \mathrm{H}), 1.52(\mathrm{~s}, 9 \mathrm{H}) .{ }^{13} \mathrm{C} \mathrm{NMR}\left(101 \mathrm{MHz}, \mathrm{CDCl}_{3}\right) \delta 166.5,150.6,144.2,139.6$, 134.0, 133.9, 130.2, 126.8, 126.1, 124.1, 122.7, 120.2, 117.8, 114.2, 111.3, 103.6, 83.7, 52.3, 51.6, 49.3, 38.8, 27.6. HRMS calcd for $\mathrm{C}_{24} \mathrm{H}_{30} \mathrm{ClN}_{2} \mathrm{O}_{5}^{+}[\mathrm{M}+\mathrm{H}]^{+} 461.1838$, found 461.1837 .

\section{- Synthesis of $( \pm)-4 c$}

The synthesis of IMDA precursor $( \pm)-\mathbf{4 c}$ was directly analogous to the synthesis of $\mathbf{4 a}$ mentioned in the main text, just starting from imine 10c instead of 10a (Scheme S7). Hydrolysis of the benzophenone imine 10c could be accomplished selectively (55\%) in the presence of both the $N$-Boc carbamate and $O$-Boc carbonate with aqueous $\mathrm{HCl}$ in EtOAc. Reductive amination between the resulting primary amine 13c and aldehyde 5 afforded the desired IMDA precursor $\mathbf{4} \mathbf{c}$ in a low-but-useable $39 \%$ isolated yield.

\section{Scheme S7. Synthesis of $( \pm)-4 c$}

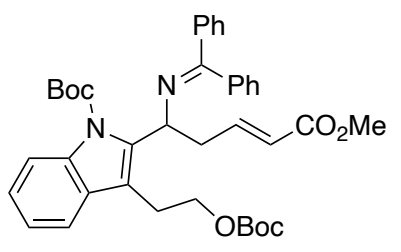

$( \pm)-10 c$

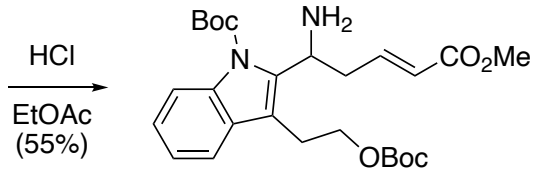

$( \pm)-13 c$

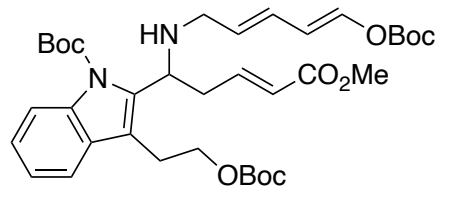

$( \pm)-4 c$

tert-Butyl-(E)-2-(1-amino-5-methoxy-5-oxopent-3-en-1-yl)-3-(2-((tert-butoxycarbonyl)oxy)ethyl)-1H-indole-1-carboxylate (13c): To a solution of imine 10c $(3.23 \mathrm{~g}, 4.83 \mathrm{mmol})$ in EtOAc $(208 \mathrm{~mL})$ under Ar atmosphere at $0{ }^{\circ} \mathrm{C}$ was slowly added dropwise $35 \%$ aq $\mathrm{HCl}(3.2 \mathrm{~mL})$. The resulting mixture was warmed to rt, stirred at that temperature for $8 \mathrm{~h}$, and then quenched with sat aq $\mathrm{NaHCO}_{3}$ and extracted with EtOAc $(3 \times 60 \mathrm{~mL})$. The combined organic layer was washed with brine, dried $\left(\mathrm{Na}_{2} \mathrm{SO}_{4}\right)$, concentrated by rotary evaporation, and purified by flash chromatography $\left(1 \% \mathrm{Et}_{3} \mathrm{~N}\right.$ in $20 \% \rightarrow 50 \%$ EtOAc/PE) to afford amine 13c (1.29 g, $2.64 \mathrm{mmol}, 55 \%)$ as a viscous yellow oil. $\mathrm{R}_{\mathrm{f}}=0.64\left(10 \% \mathrm{MeOH} / \mathrm{CH}_{2} \mathrm{Cl}_{2}\right)$. IR (thin film) v3410.2, 3051.4, 1724.4, $1600.9,1456.3,1369.5,1278.8,1163.1,1030.0,744.5,638.4 .{ }^{1} \mathrm{H}$ NMR $\left(400 \mathrm{MHz}, \mathrm{CDCl}_{3}\right) \delta 7.98-7.94(\mathrm{~m}, 1 \mathrm{H}), 7.52-7.47$ $(\mathrm{m}, 1 \mathrm{H}), 7.31-7.20(\mathrm{~m}, 2 \mathrm{H}), 6.95(\mathrm{dt}, J=15.3,7.5 \mathrm{~Hz}, 1 \mathrm{H}), 5.90(\mathrm{~d}, J=15.6 \mathrm{~Hz}, 1 \mathrm{H}), 4.49(\mathrm{dd}, J=8.1,6.7 \mathrm{~Hz}, 1 \mathrm{H}), 4.25-$ $4.14(\mathrm{~m}, 2 \mathrm{H}), 3.69(\mathrm{~s}, 3 \mathrm{H}), 3.10(\mathrm{t}, J=7.0 \mathrm{~Hz}, 2 \mathrm{H}), 2.92(\mathrm{dtd}, J=9.3,8.2,1.2 \mathrm{~Hz}, 1 \mathrm{H}), 2.80(\mathrm{dtd}, J=8.3,6.9,1.5 \mathrm{~Hz}, 1 \mathrm{H})$, 
$1.74-1.69(\mathrm{~m}, 9 \mathrm{H}), 1.44(\mathrm{~s}, 9 \mathrm{H}) ;{ }^{13} \mathrm{C}$ NMR $\left(101 \mathrm{MHz}, \mathrm{CDCl}_{3}\right) \delta 166.8,153.3,151.0,146.9,140.5,135.7,129.3,124.5,122.8$, 122.7, 118.5, 115.7, 115.3, 84.6, 82.2, 65.7, 51.4, 48.8, 38.6, 28.2, 27.7, 24.1. HRMS calcd for $\mathrm{C}_{26} \mathrm{H}_{37} \mathrm{~N}_{2} \mathrm{O}_{7}{ }^{+}[\mathrm{M}+\mathrm{H}]^{+} 489.2595$, found 489.2598 .

tert-Butyl 3-(2-((tert-butoxycarbonyl)oxy)ethyl)-2-((4E,10E,12E)-17,17-dimethyl-3,15-dioxo-2,14,16-trioxa-8-azaoctadeca-4,10,12-trien-7-yl)-1H-indole-1-carboxylate (4c): A slurry of amine $\mathbf{1 3 c}(910 \mathrm{mg}, 1.86 \mathrm{mmol})$, aldehyde $\mathbf{5}^{6}(368 \mathrm{mg}$, $1.86 \mathrm{mmol})$, and $4 \AA \mathrm{mol}$ sieves $(20 \mathrm{~g})$ in dry THF $(100 \mathrm{~mL})$ was stirred at $-20^{\circ} \mathrm{C}$ under Ar for $30 \mathrm{~min}$. After warming to rt, a solution of $\mathrm{NaBH}_{3} \mathrm{CN}$ (701 mg, $11.16 \mathrm{mmol}$ ) in $\mathrm{MeOH}$ was added in the system via syringe. After stirring at $\mathrm{rt}$ for $30 \mathrm{~min}$, a solution of acetic acid (335 mg, $5.58 \mathrm{mmol}$ ) in $\mathrm{MeOH}$ was added in the reaction system, which was stirred for an additional 5 h. The resulting mixture was filtered through Celite (washed by THF) and the filtrate was concentrated by rotary evaporation. The resulting residue was purified by flash chromatography $\left(1 \% \mathrm{Et}_{3} \mathrm{~N}\right.$ in $\left.20 \% \mathrm{EtOAc} / \mathrm{PE}\right)$ to give afford desired secondary amine $4 \mathbf{c}(480 \mathrm{mg}, 0.72 \mathrm{mmol}, 39 \%)$ as a thick yellow oil. $\mathrm{R}_{\mathrm{f}}=0.34\left(1 \% \mathrm{Et}_{3} \mathrm{~N}\right.$ in $20 \%$ EtOAc/PE). IR (thin film) $v 3257.7$, 2947.2, 2031.0, 1735.9, 1637.6, 1450.5, 1165.0, 1010.7, 798.5, 746.5. ${ }^{1} \mathrm{H}$ NMR (400 MHz, CD $\left.{ }_{3} \mathrm{OD}\right) \delta 7.96(\mathrm{~d}, J=8.2 \mathrm{~Hz}, 1 \mathrm{H})$, $7.54(\mathrm{~d}, J=7.7 \mathrm{~Hz}, 1 \mathrm{H}), 7.26(\mathrm{t}, J=7.8 \mathrm{~Hz}, 1 \mathrm{H}), 7.20(\mathrm{t}, J=7.4 \mathrm{~Hz}, 1 \mathrm{H}), 7.06(\mathrm{~d}, J=11.8 \mathrm{~Hz}, 1 \mathrm{H}), 6.89(\mathrm{dt}, J=15.3,7.5 \mathrm{~Hz}$, $1 \mathrm{H}), 6.03-5.80(\mathrm{~m}, 3 \mathrm{H}), 5.66-5.57(\mathrm{~m}, 1 \mathrm{H}), 4.36(\mathrm{~s}, 1 \mathrm{H}), 4.20(\mathrm{dt}, J=10.6,6.8 \mathrm{~Hz}, 1 \mathrm{H}), 4.15-4.06(\mathrm{~m}, 1 \mathrm{H}), 3.61(\mathrm{~s}, 3 \mathrm{H})$, $3.19-2.98(\mathrm{~m}, 4 \mathrm{H}), 2.92(\mathrm{dt}, J=14.4,7.3 \mathrm{~Hz}, 1 \mathrm{H}), 2.82(\mathrm{dt}, J=14.8,7.6 \mathrm{~Hz}, 1 \mathrm{H}), 1.69(\mathrm{~s}, 9 \mathrm{H}), 1.45(\mathrm{~s}, 9 \mathrm{H}), 1.37(\mathrm{~s}, 9 \mathrm{H}) ;{ }^{13} \mathrm{C}$ NMR (101 MHz, CD 3 OD) $\delta 166.9,153.6,151.4,150.8,146.7,139.4,136.3,136.0,130.6,129.1,126.7,124.5,122.7,122.2$, 118.5, 115.5, 114.1, 84.9, 82.9, 81.5, 78.1, 65.6, 53.8, 50.6, 48.6, 36.7, 27.1, 26.6, 26.5, 23.8. HRMS calcd for $\mathrm{C}_{36} \mathrm{H}_{51} \mathrm{~N}_{2} \mathrm{O}_{10}{ }^{+}$ $[\mathrm{M}+\mathrm{H}]^{+} 671.3538$, found 671.3534 . 
-X-Ray Crystallographic Data for ( $( \pm)-17+\mathrm{NaOTf}(2: 1)$ recrystallized from $\mathrm{CDCl}_{3}$
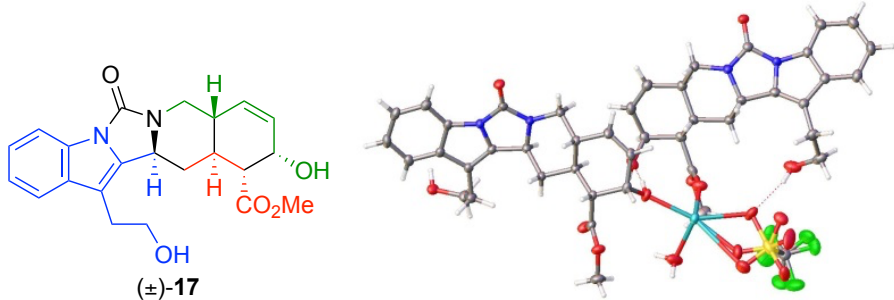

Table S1. Crystal Date and Structure Refinement for ( \pm )-17 (CCDC-2082133)

\begin{tabular}{|c|c|}
\hline Identification code & $( \pm)-17$ \\
\hline Empirical formula & $\mathrm{C}_{45} \mathrm{H}_{50} \mathrm{~F}_{3} \mathrm{~N}_{4} \mathrm{O}_{14} \mathrm{SNa}$ \\
\hline Formula weight & 982.94 \\
\hline Temperature/K & $160(15) \mathrm{K}$ \\
\hline Crystal system & monoclinic \\
\hline Space group & $\mathrm{P} 2{ }_{1} / \mathrm{c}$ \\
\hline $\mathrm{a} / \AA$ & $11.1701(3)$ \\
\hline $\mathrm{b} / \AA$ & $21.3786(5)$ \\
\hline $\mathrm{c} / \AA$ & $18.8905(5)$ \\
\hline$\alpha /{ }^{\circ}$ & 90 \\
\hline$\beta /{ }^{\circ}$ & $90.194(2)$ \\
\hline$\gamma /{ }^{\circ}$ & 90 \\
\hline Volume/ $\AA^{3}$ & $4511.04(19)$ \\
\hline $\mathrm{Z}$ & 2 \\
\hline $\mathrm{Q}_{\text {calc }} \mathrm{g} / \mathrm{cm}^{3}$ & 1.447 \\
\hline$\mu / \mathrm{mm}^{-1}$ & 1.475 \\
\hline $\mathrm{F}(000)$ & 2056.0 \\
\hline Crystal size $/ \mathrm{mm}^{3}$ & $0.4 \times 0.3 \times 0.3$ \\
\hline Radiation & $\operatorname{CuK} \alpha(\lambda=1.54184)$ \\
\hline $2 \Theta$ range for data collection ${ }^{\circ}$ & 7.916 to 143.482 \\
\hline Index ranges & $-12 \leq \mathrm{h} \leq 13,-19 \leq \mathrm{k} \leq 26,-23 \leq 1 \leq 22$ \\
\hline Reflections collected & 24926 \\
\hline Independent reflections & $8552\left[\mathrm{R}_{\text {int }}=0.0508, \mathrm{R}_{\text {sigma }}=0.0454\right]$ \\
\hline Data/restraints/parameters & $8552 / 3 / 682$ \\
\hline Goodness-of-fit on $\mathrm{F}^{2}$ & 1.031 \\
\hline Final $\mathrm{R}$ indexes $[\mathrm{I}>=2 \sigma(\mathrm{I})]$ & $\mathrm{R}_{1}=0.0614, \mathrm{wR}_{2}=0.1681$ \\
\hline Final $\mathrm{R}$ indexes [all data] & $\mathrm{R}_{1}=0.0681, \mathrm{wR}_{2}=0.1762$ \\
\hline Largest diff. peak/hole/e $\AA^{3}$ & $0.83 /-0.81$ \\
\hline
\end{tabular}


- NMR Spectra for New Compounds

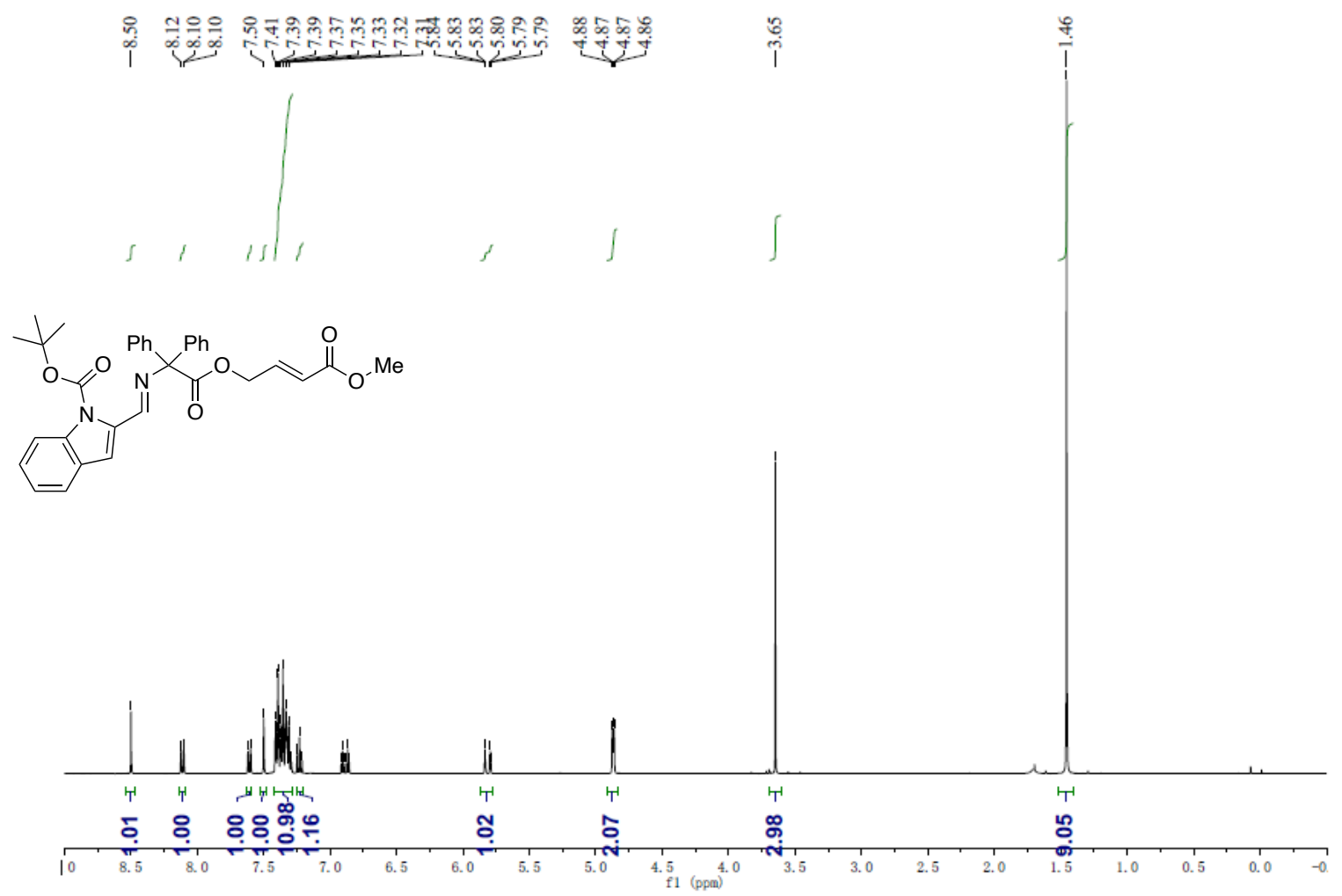

Figure S2. ${ }^{1} \mathrm{H}$ NMR Spectrum of $8 \mathrm{a}\left(\mathrm{CDCl}_{3}, 400 \mathrm{MHz}\right)$

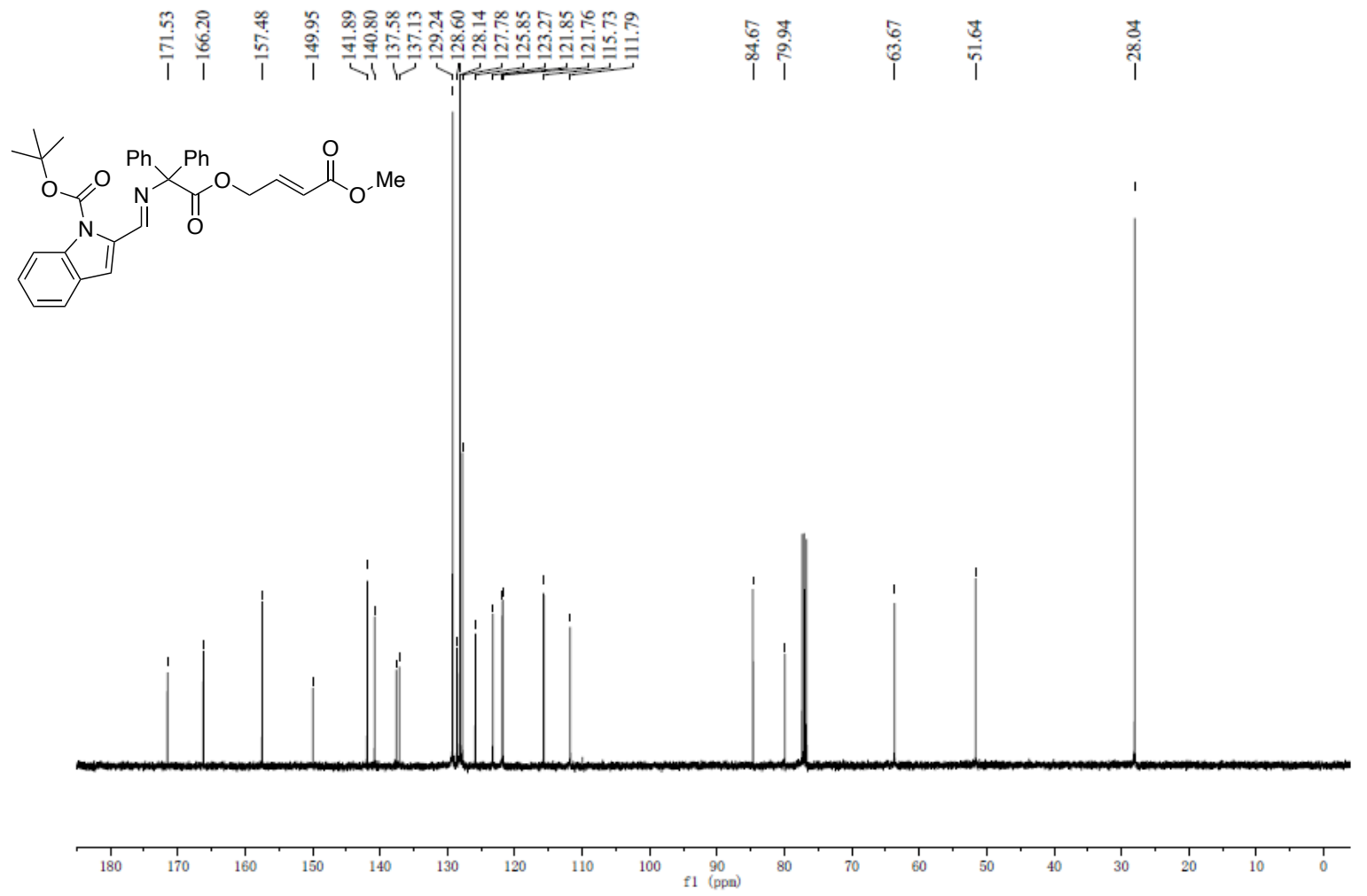

Figure S3. ${ }^{13} \mathrm{C}$ NMR Spectrum of $8 \mathrm{a}\left(\mathrm{CDCl}_{3}, 101 \mathrm{MHz}\right)$ 


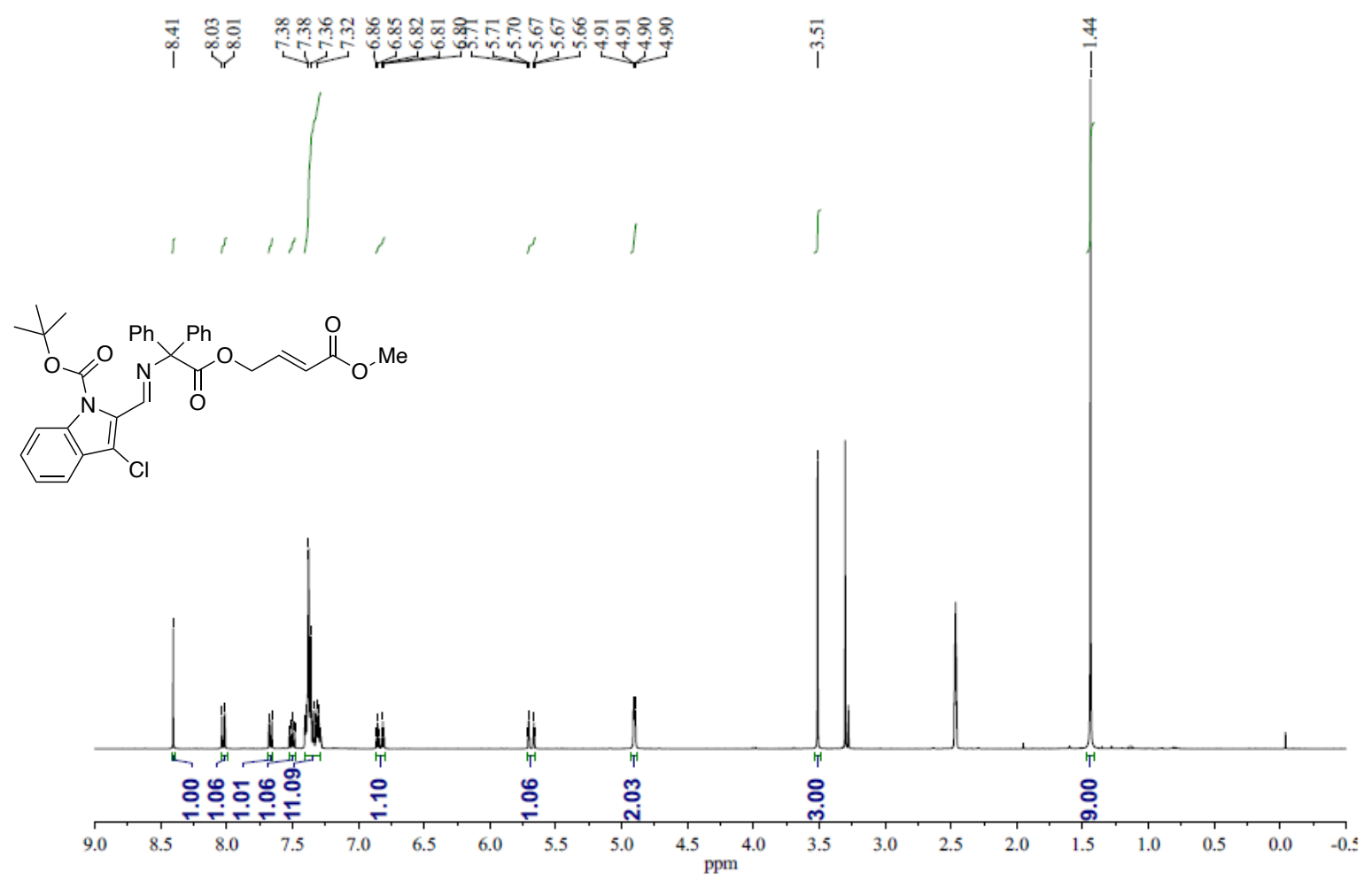

Figure S4. ${ }^{1} \mathrm{H}$ NMR Spectrum of $8 \mathrm{~b}$ (DMSO, $400 \mathrm{MHz}$ )

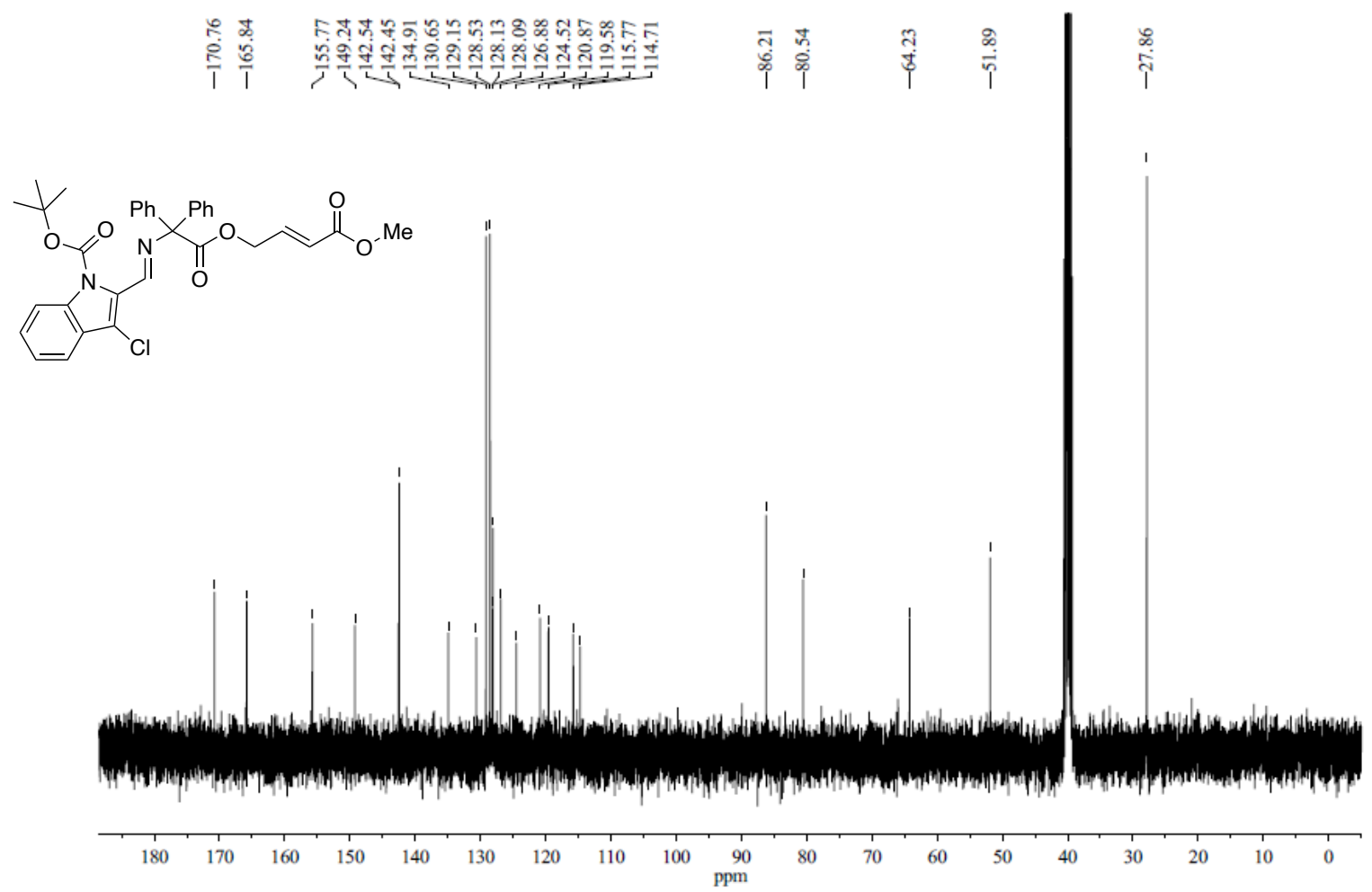

Figure S5. ${ }^{13} \mathrm{C}$ NMR Spectrum of $8 \mathrm{~b}$ (DMSO, $\left.101 \mathrm{MHz}\right)$ 


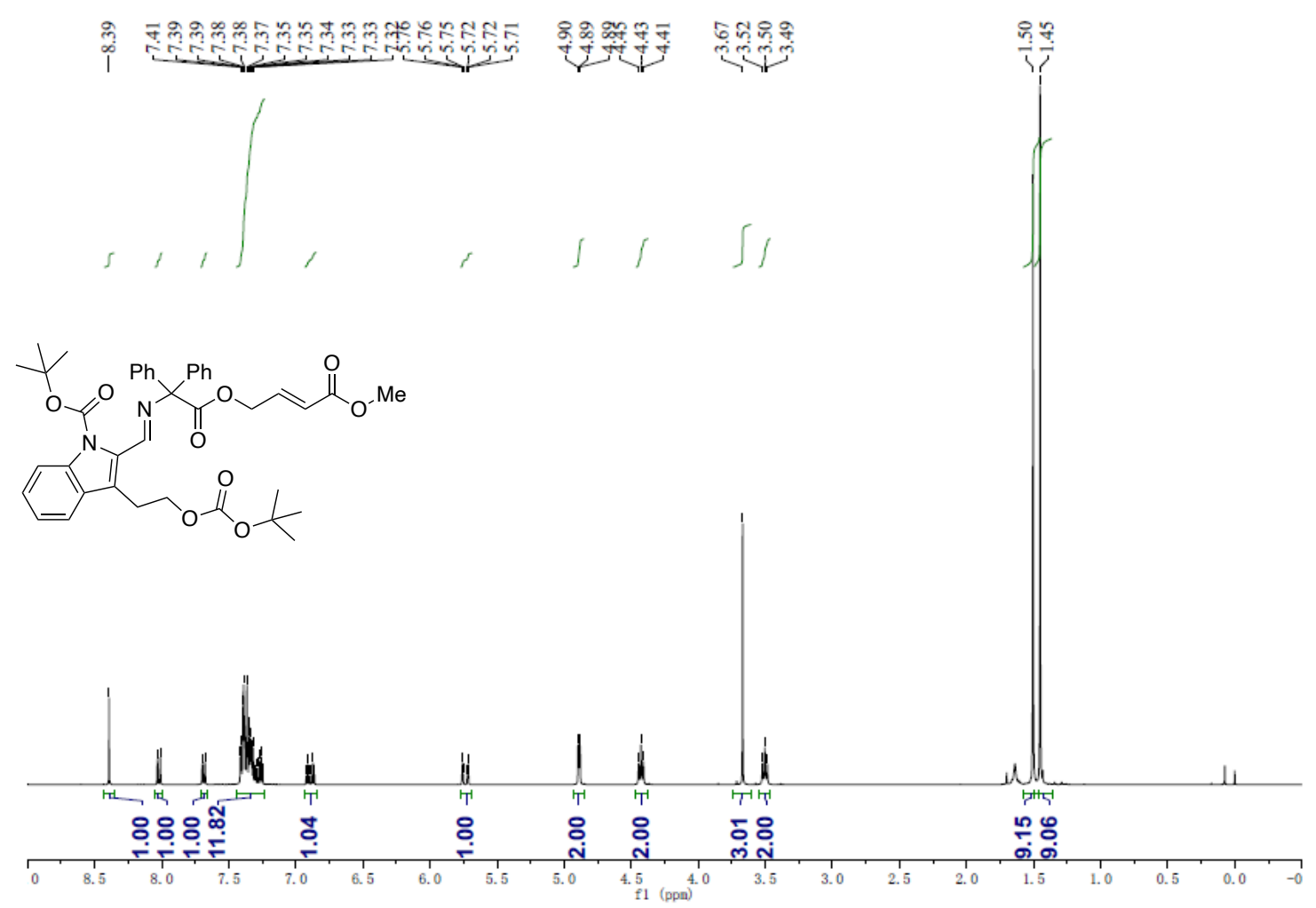

Figure S6. ${ }^{1} \mathrm{H}$ NMR Spectrum of $8 \mathrm{c}\left(\mathrm{CDCl}_{3}, 400 \mathrm{MHz}\right)$

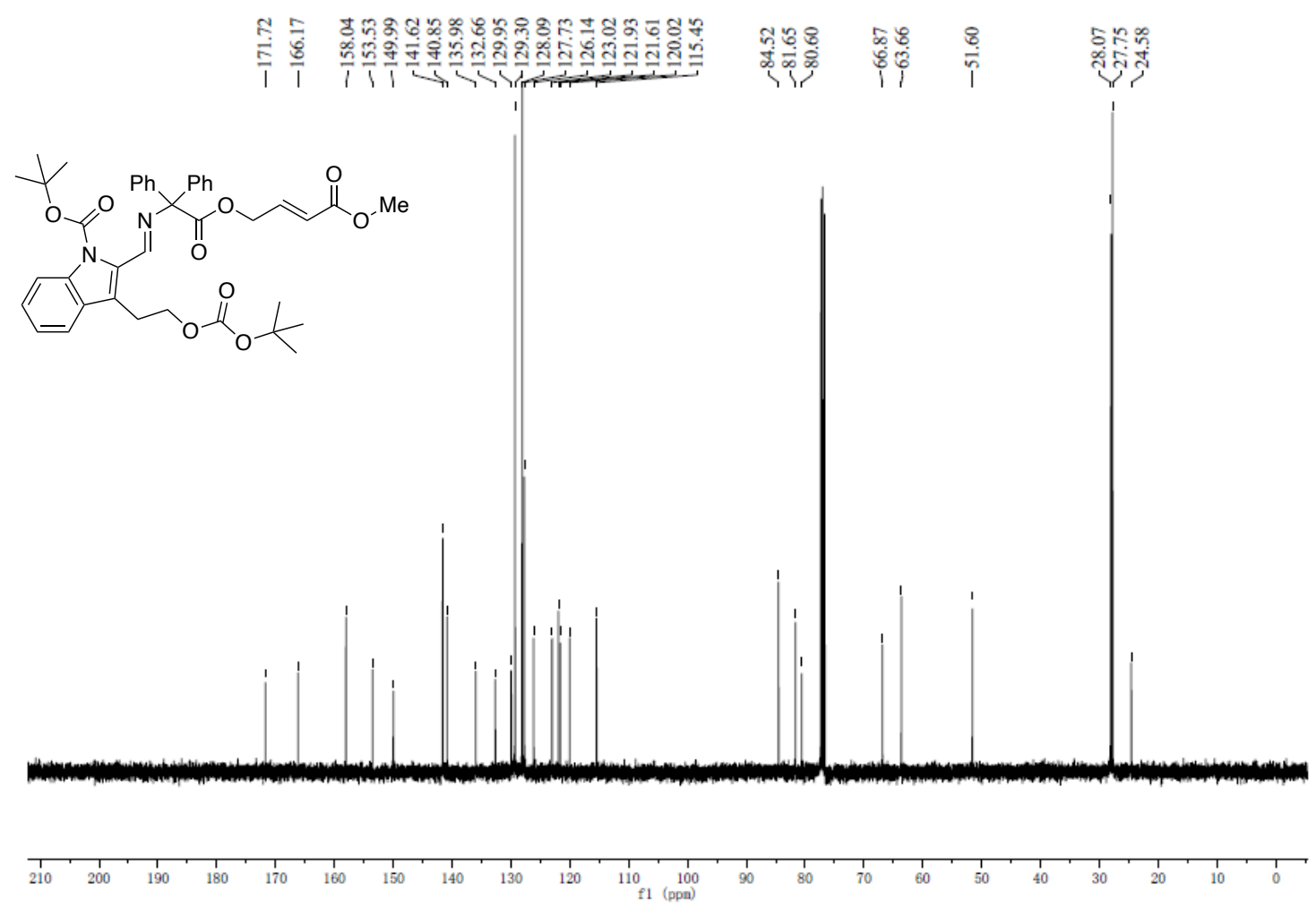

Figure S7. ${ }^{13} \mathrm{C}$ NMR Spectrum of $8 \mathrm{c}\left(\mathrm{CDCl}_{3}, 101 \mathrm{MHz}\right)$ 


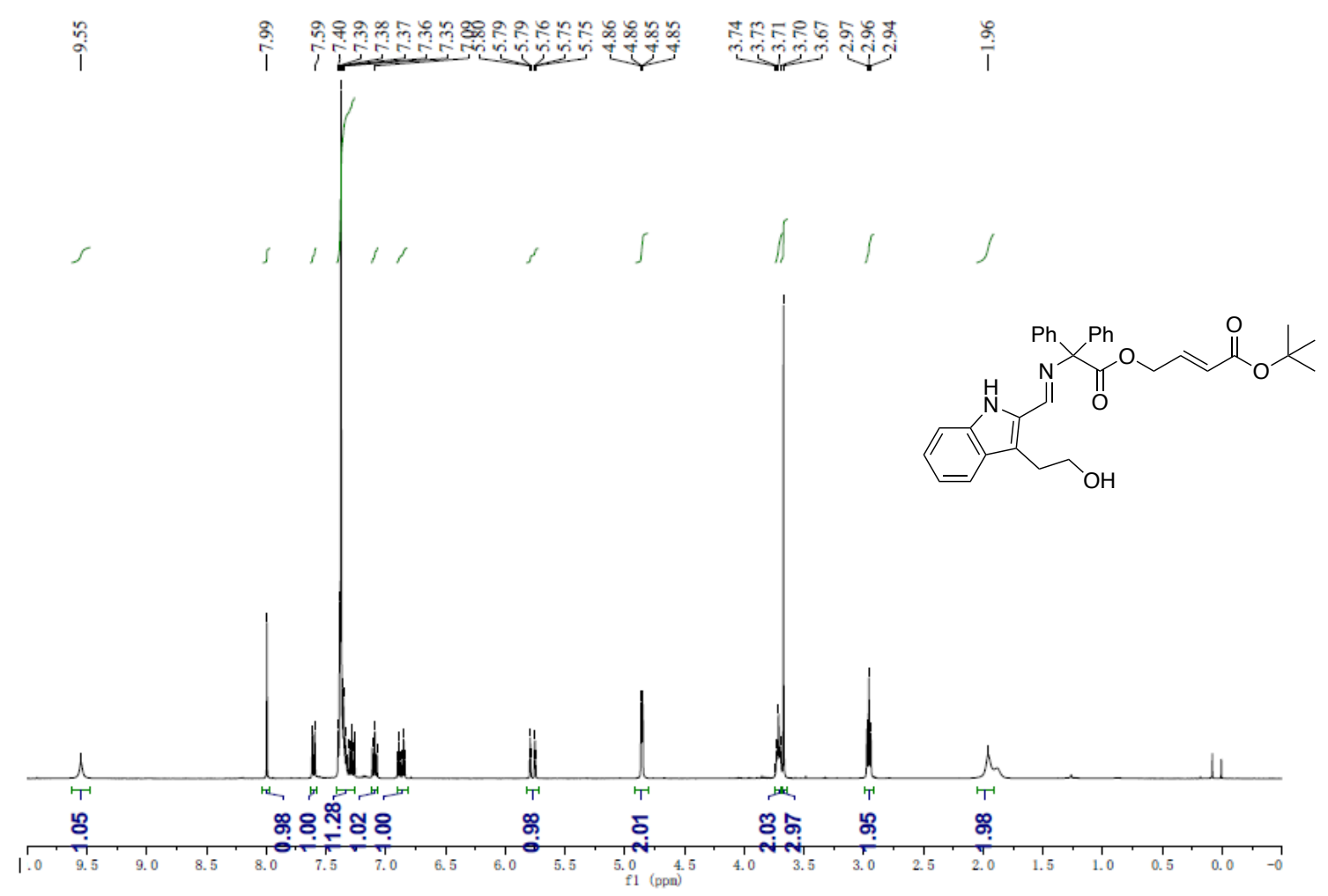

Figure S8. ${ }^{1} \mathrm{H}$ NMR Spectrum of $8 \mathrm{~d}\left(\mathrm{CDCl}_{3}, 400 \mathrm{MHz}\right)$

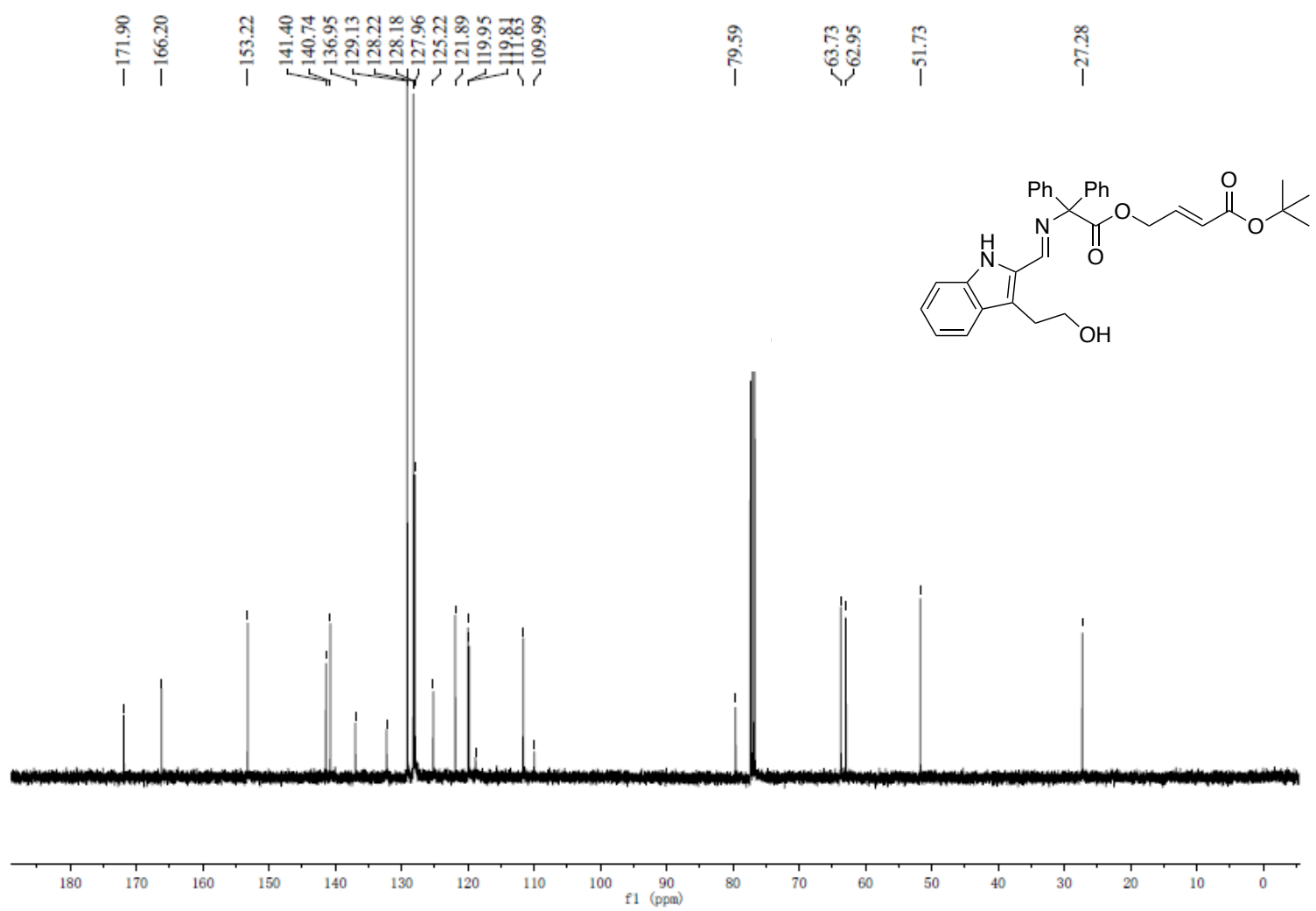

Figure S9. ${ }^{13} \mathrm{C}$ NMR Spectrum of $8 \mathrm{~d}\left(\mathrm{CDCl}_{3}, 101 \mathrm{MHz}\right)$ 


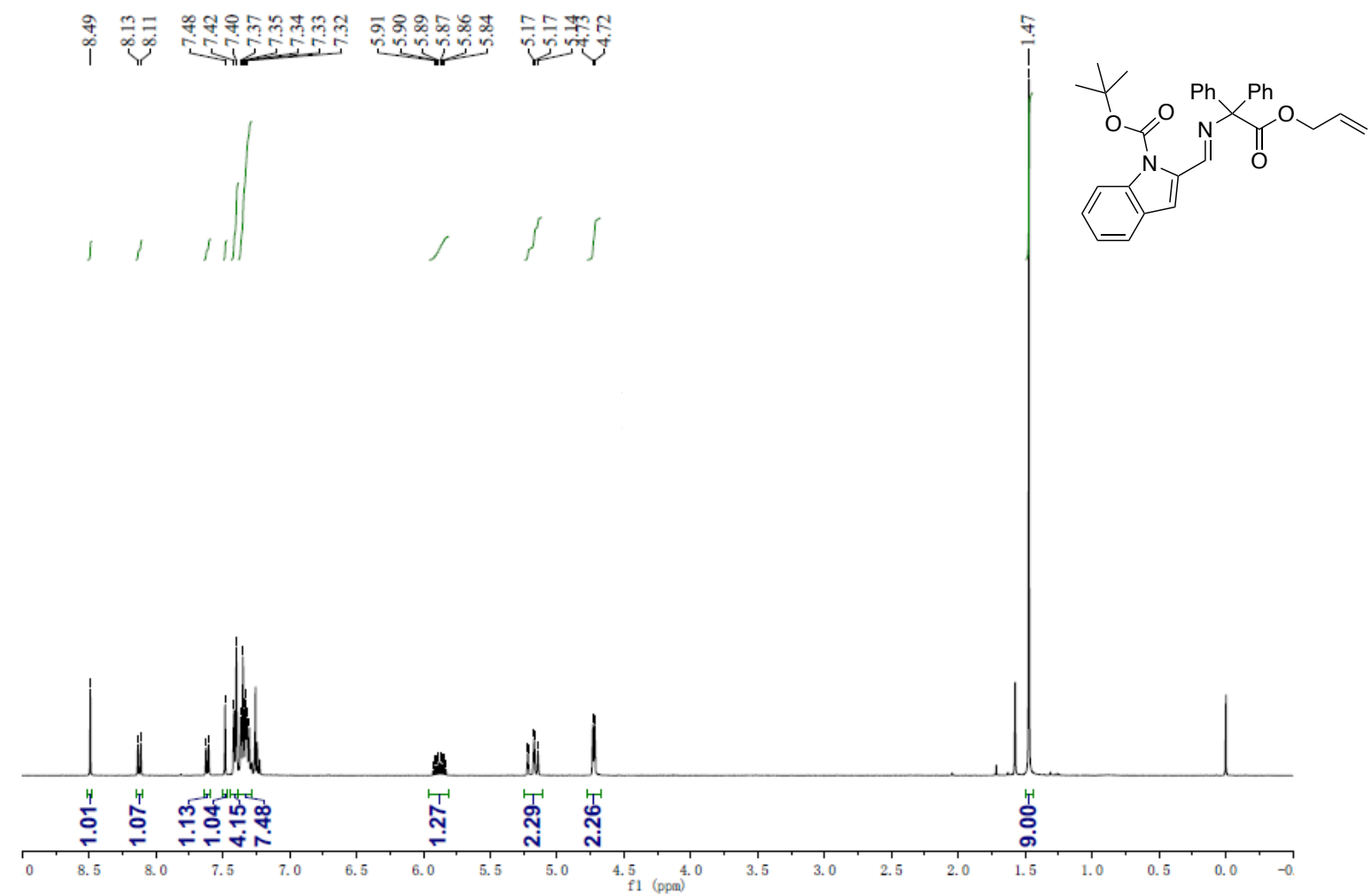

Figure S10. ${ }^{1} \mathrm{H}$ NMR Spectrum of 9a $\left(\mathrm{CDCl}_{3}, 400 \mathrm{MHz}\right)$

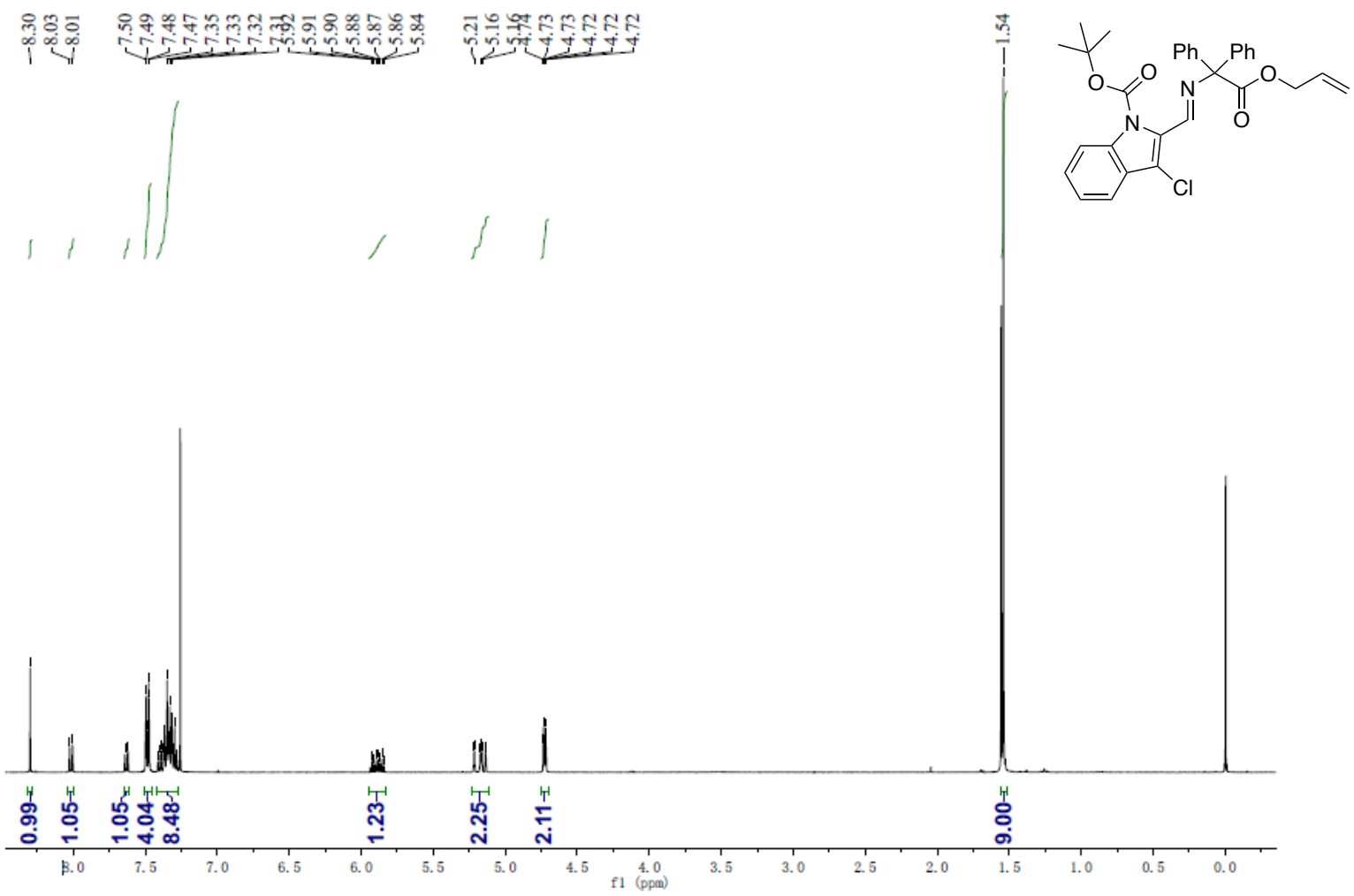

Figure S11. ${ }^{1} \mathrm{H}$ NMR Spectrum of $9 \mathrm{~b}\left(\mathrm{CDCl}_{3}, 101 \mathrm{MHz}\right)$ 


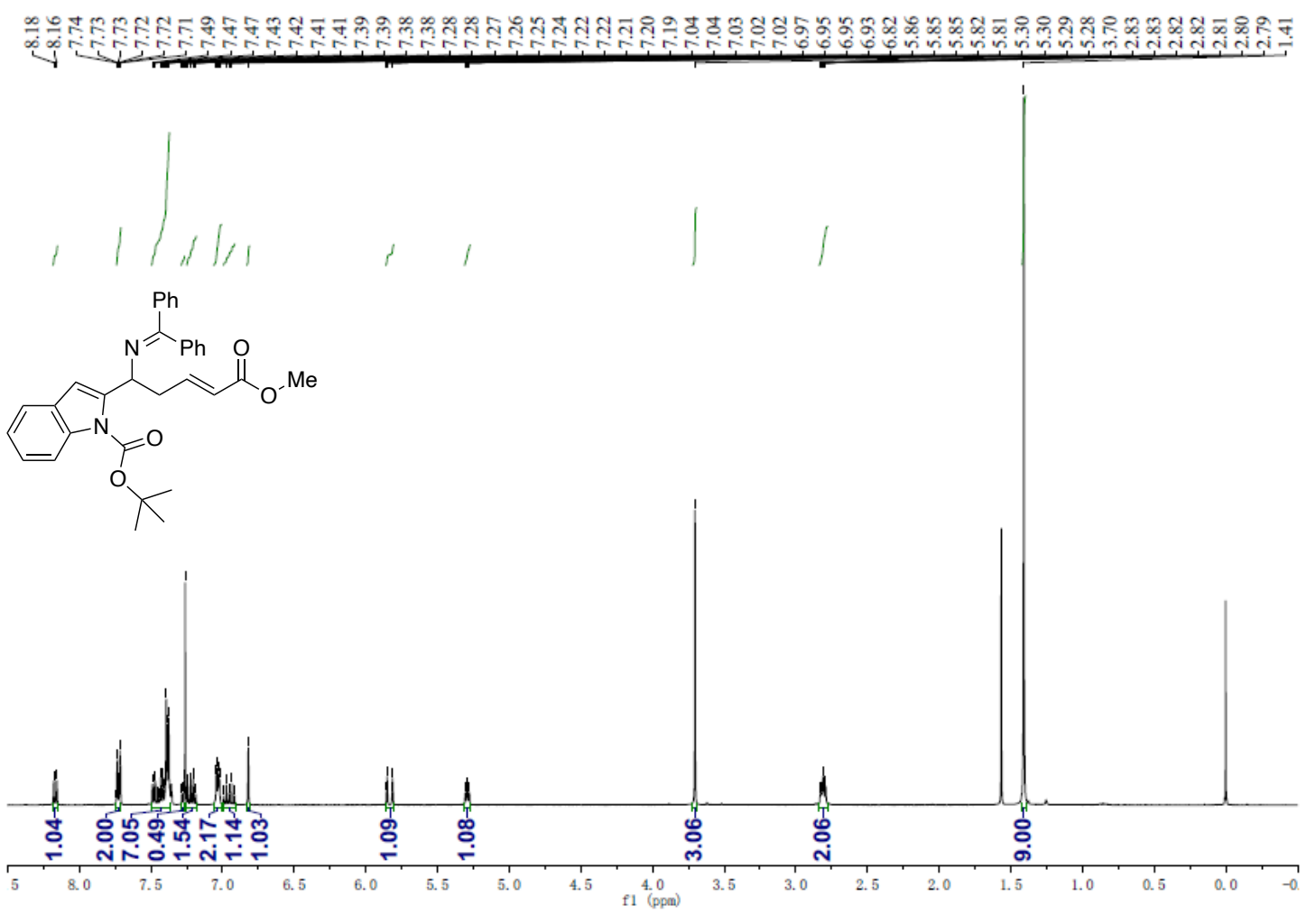

Figure S12. ${ }^{1} \mathrm{H}$ NMR Spectrum of $( \pm)-10 a\left(\mathrm{CDCl}_{3}, 400 \mathrm{MHz}\right)$
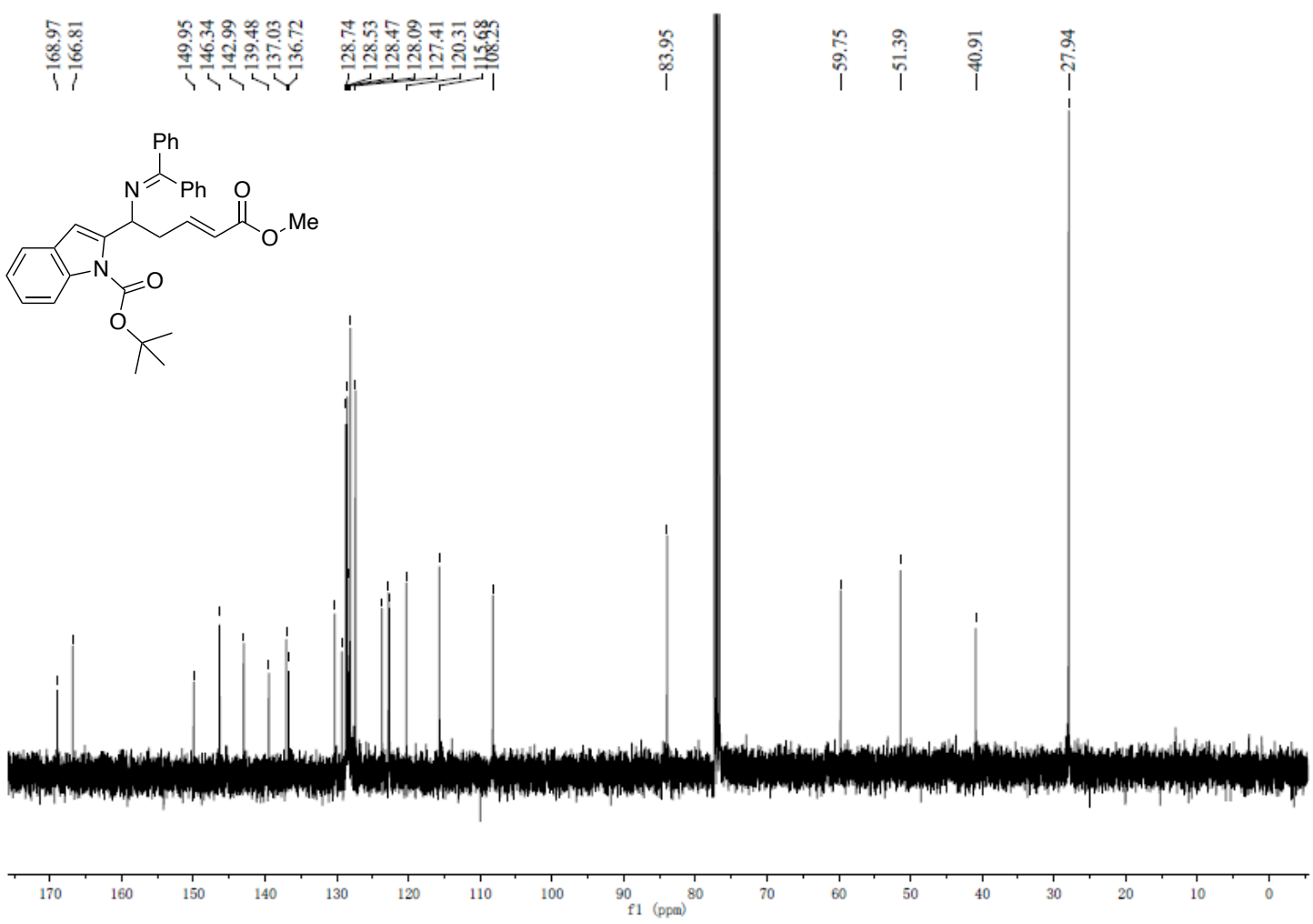

Figure S13. ${ }^{13} \mathrm{C}$ NMR Spectrum of $( \pm)-10 a\left(\mathrm{CDCl}_{3}, 101 \mathrm{MHz}\right)$ 


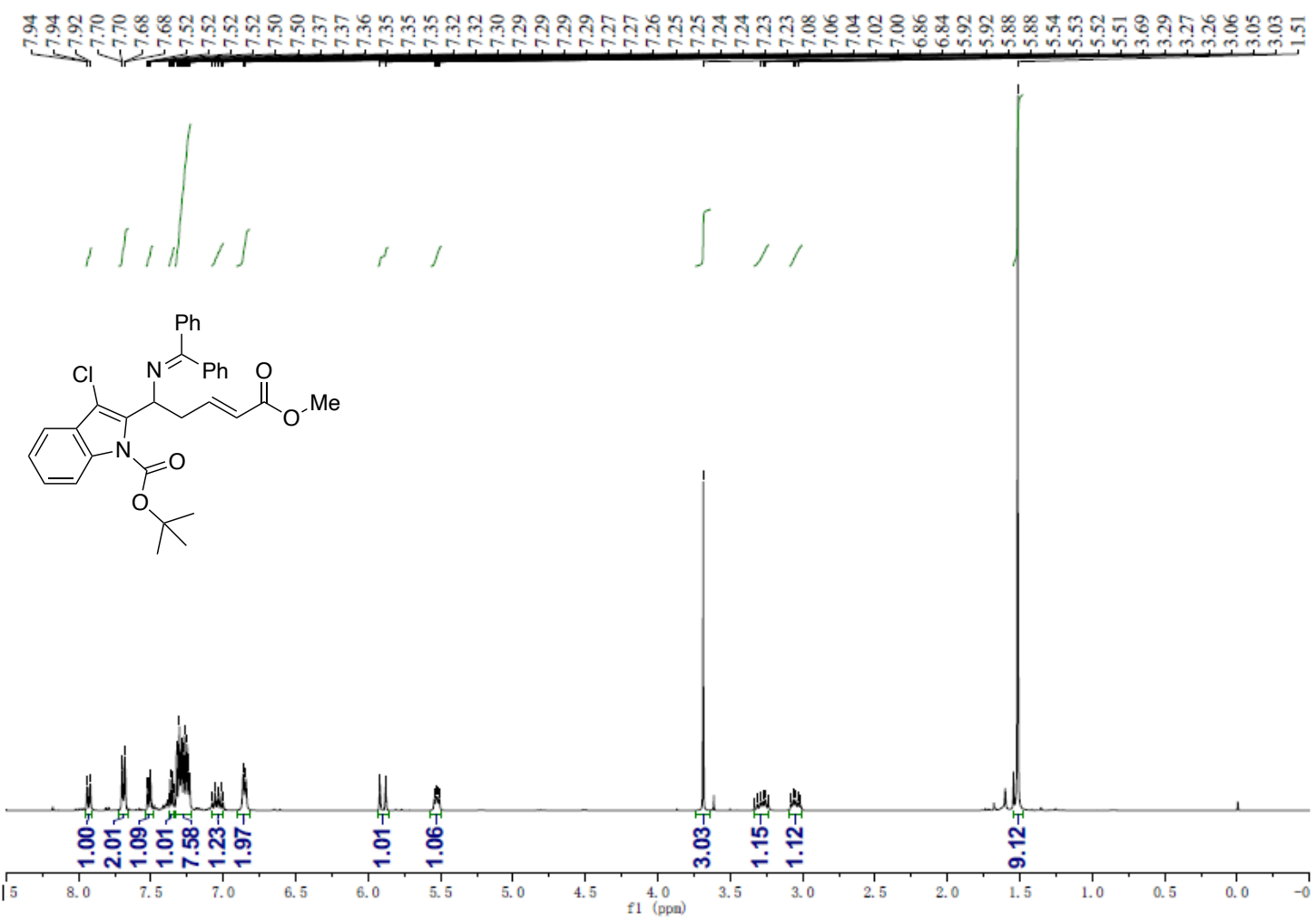

Figure S14. ${ }^{1} \mathrm{H}$ NMR Spectrum of $( \pm)-10 \mathrm{~b}\left(\mathrm{CDCl}_{3}, 400 \mathrm{MHz}\right)$

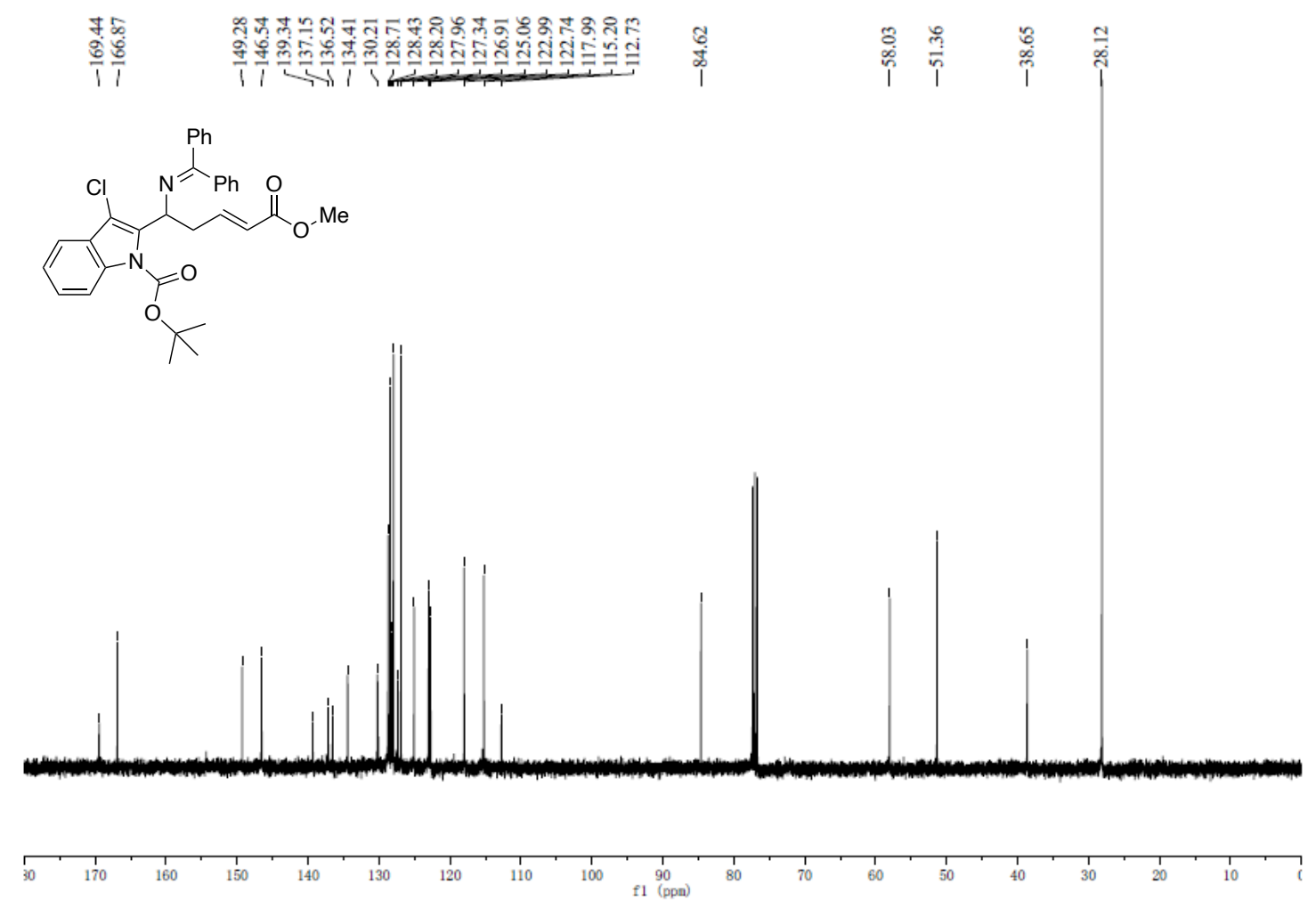

Figure S15. ${ }^{13} \mathrm{C}$ NMR Spectrum of $( \pm)-10 \mathrm{~b}\left(\mathrm{CDCl}_{3}, 101 \mathrm{MHz}\right)$ 


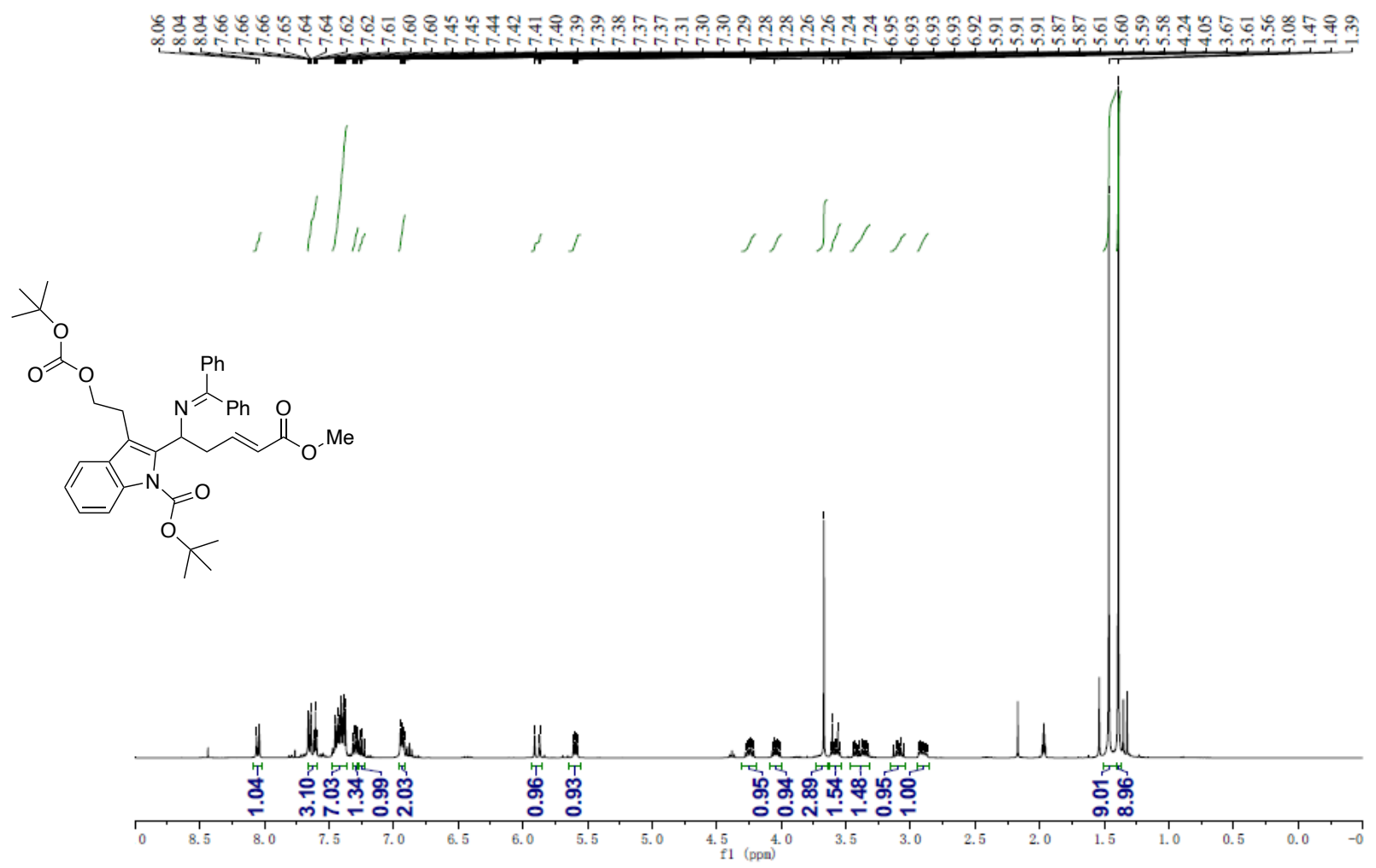

Figure S16. ${ }^{1} \mathrm{H}$ NMR Spectrum of $( \pm)-10 \mathrm{c}\left(\mathrm{CD}_{3} \mathrm{CN}, 400 \mathrm{MHz}\right)$

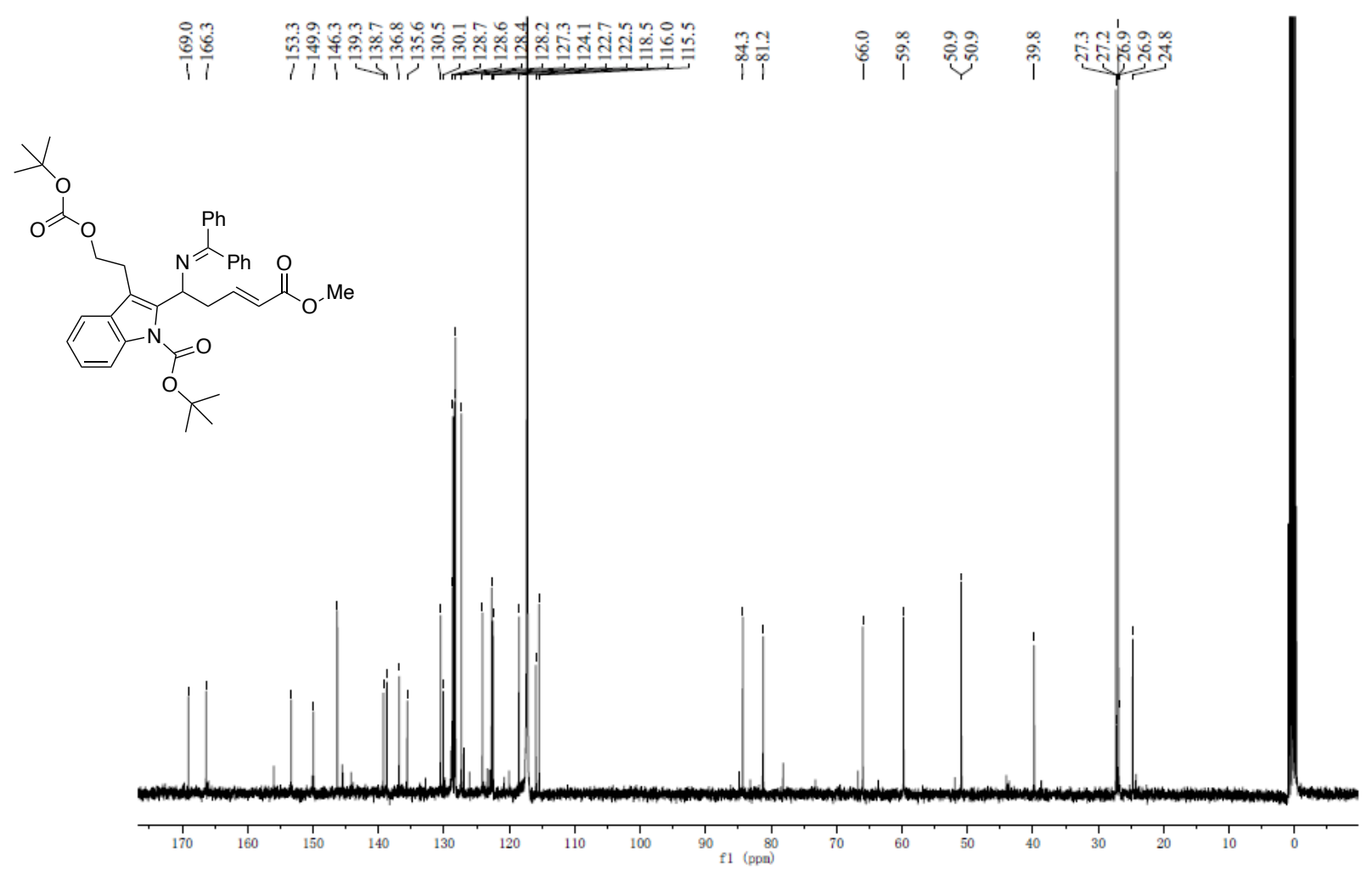

Figure S17. ${ }^{13} \mathrm{C}$ NMR Spectrum of $( \pm)-10 \mathrm{c}\left(\mathrm{CD}_{3} \mathrm{CN}, 101 \mathrm{MHz}\right)$ 


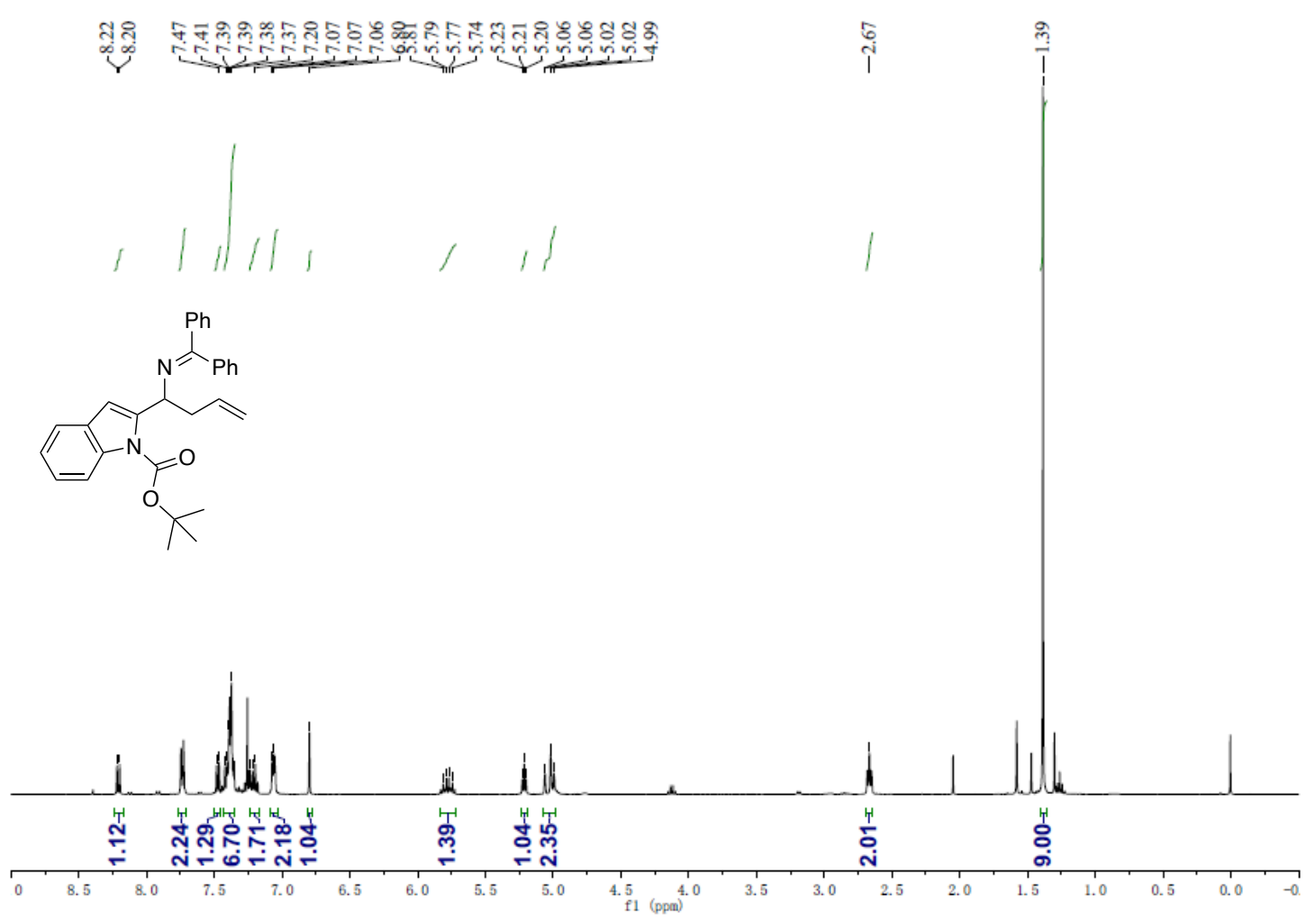

Figure S18. ${ }^{1} \mathrm{H}$ NMR Spectrum of ( $( \pm)-11$ a $\left(\mathrm{CDCl}_{3}, 400 \mathrm{MHz}\right)$

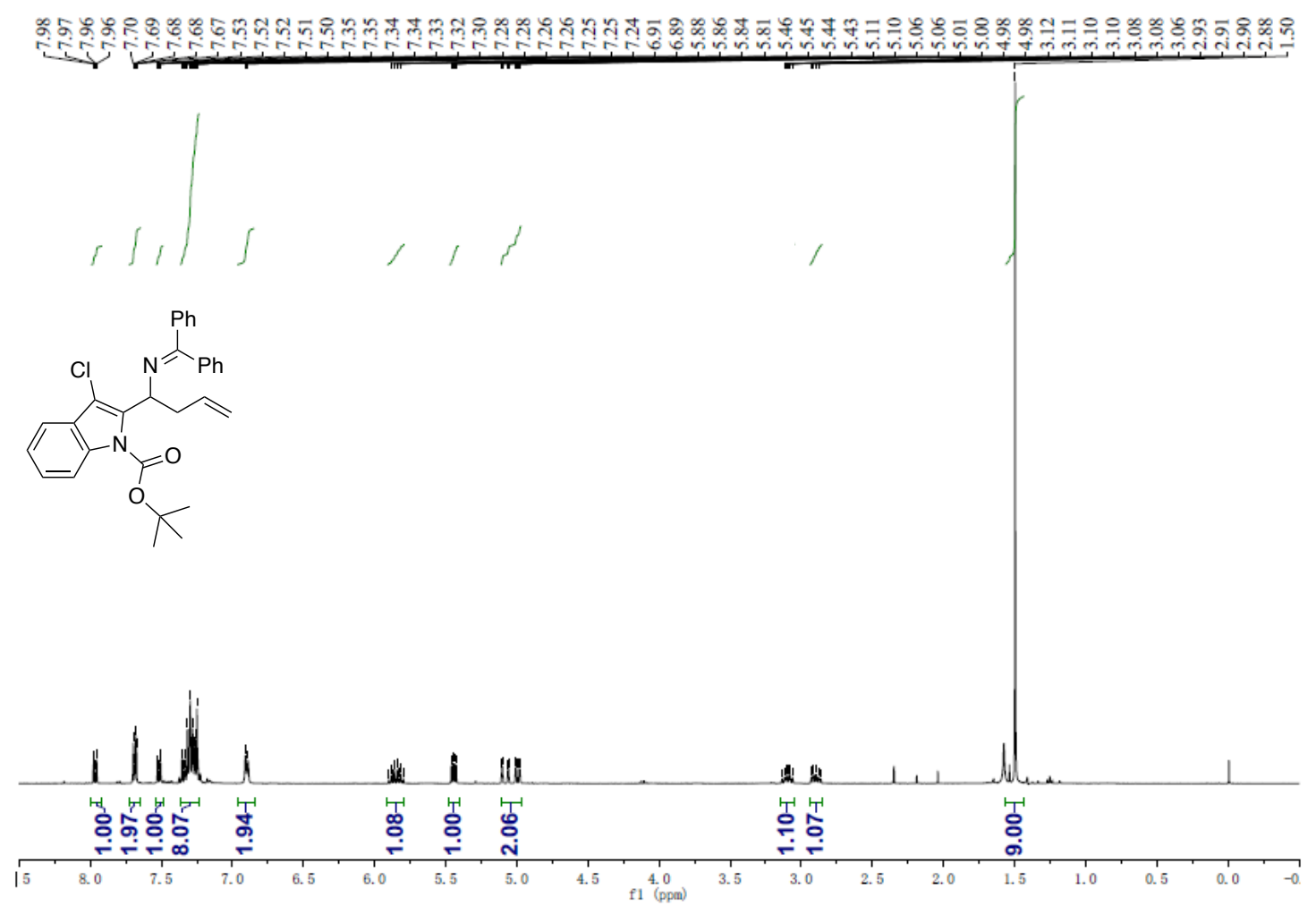

Figure S19. ${ }^{1} \mathrm{H}$ NMR Spectrum of $( \pm)-11 \mathrm{~b}\left(\mathrm{CDCl}_{3}, 400 \mathrm{MHz}\right)$ 


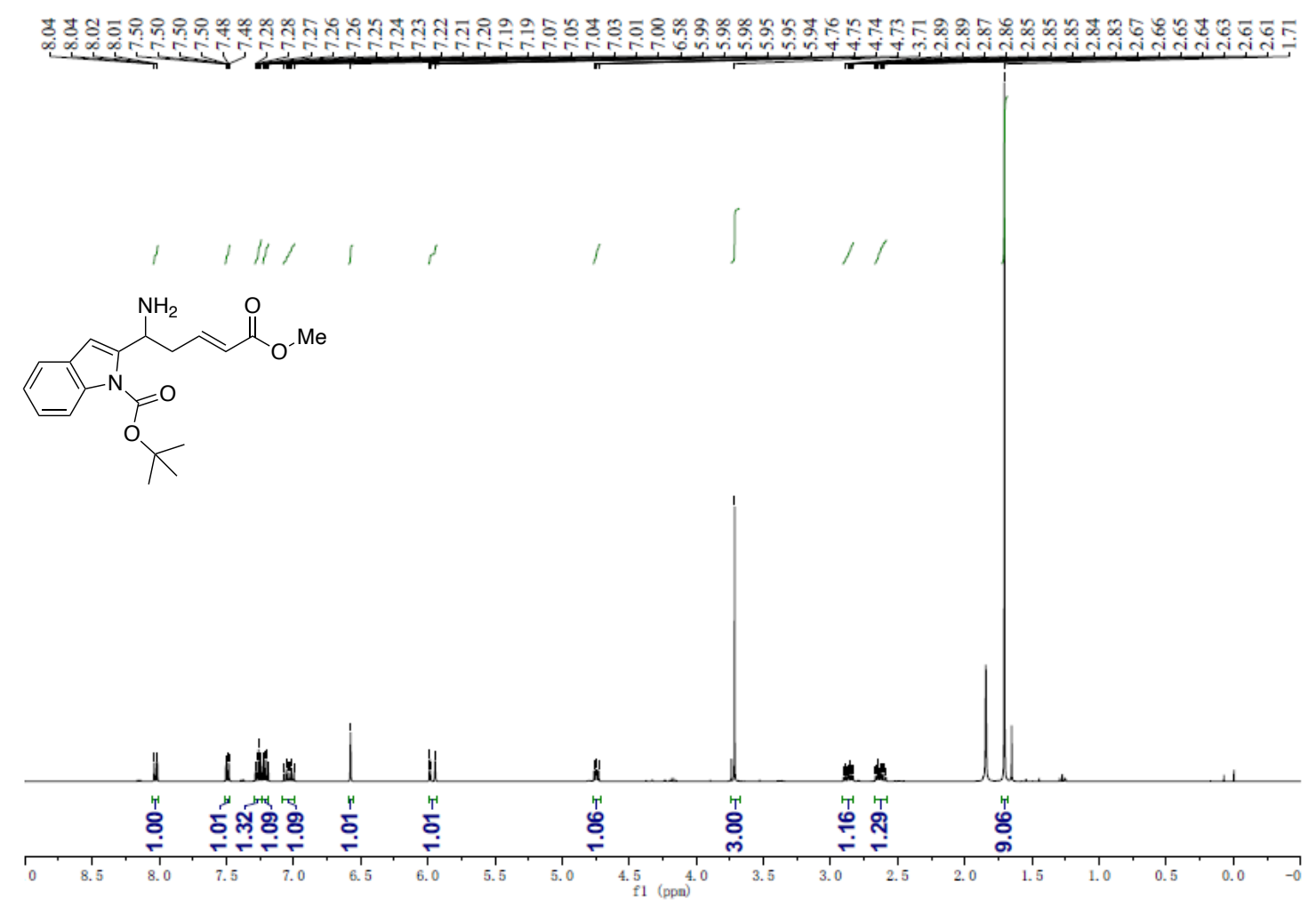

Figure S20. ${ }^{1} \mathrm{H}$ NMR Spectrum of $( \pm)-13 a\left(\mathrm{CDCl}_{3}, 400 \mathrm{MHz}\right)$
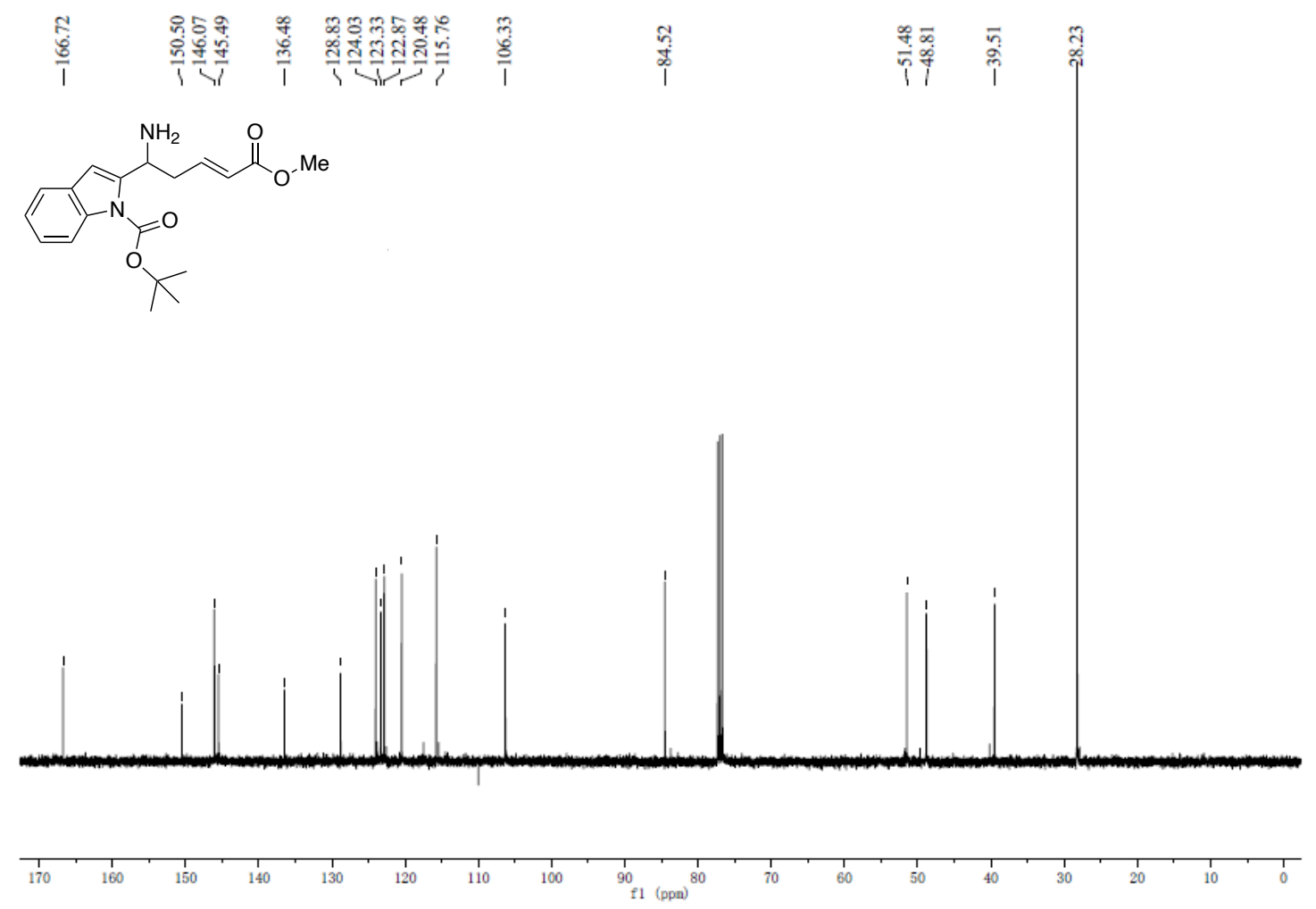

Figure S21. ${ }^{13} \mathrm{C}$ NMR Spectrum of $( \pm)-13 a\left(\mathrm{CDCl}_{3}, 101 \mathrm{MHz}\right)$ 


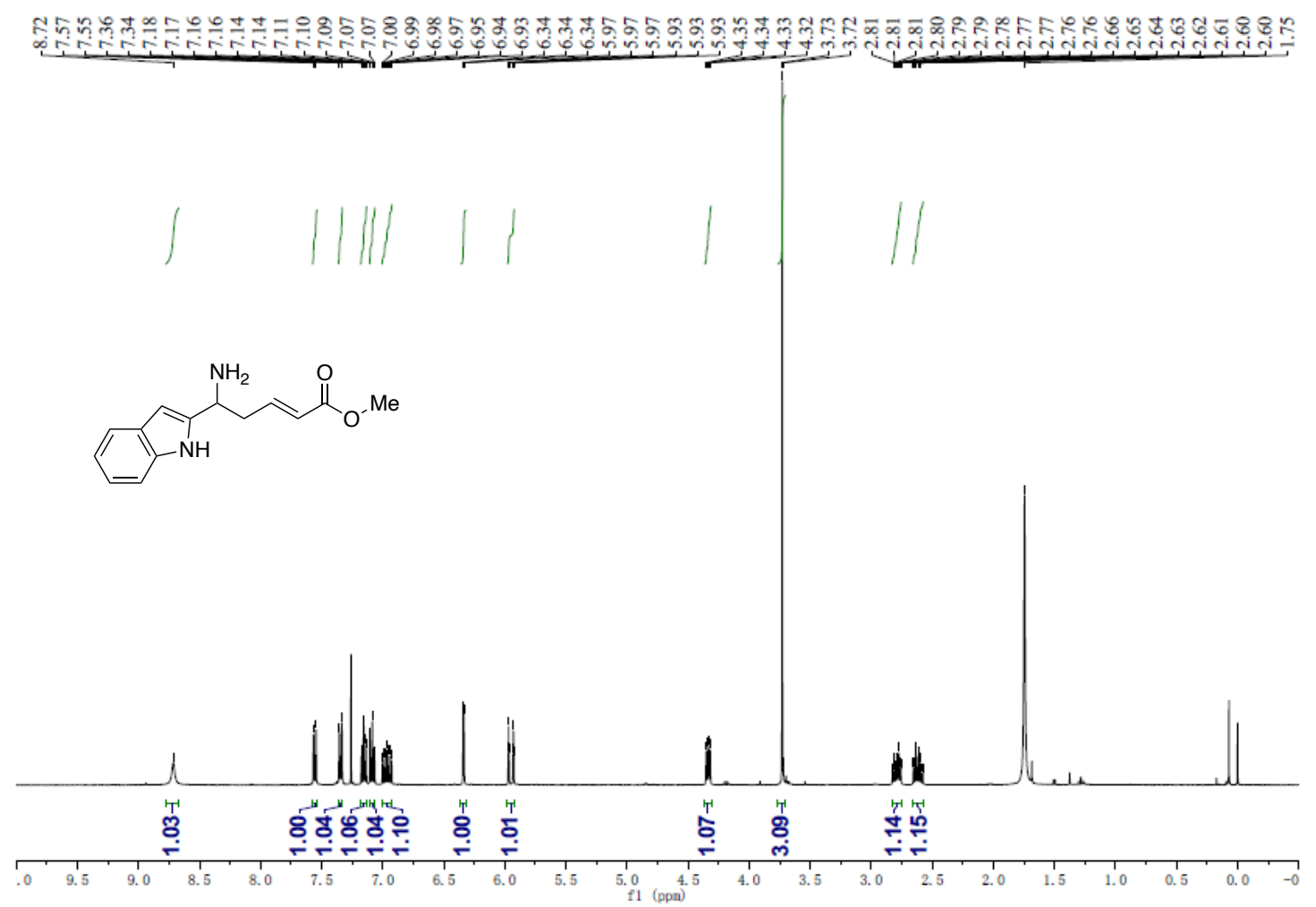

Figure S22. ${ }^{1} \mathrm{H}$ NMR Spectrum of $( \pm)-\mathrm{S} 9\left(\mathrm{CDCl}_{3}, 400 \mathrm{MHz}\right)$
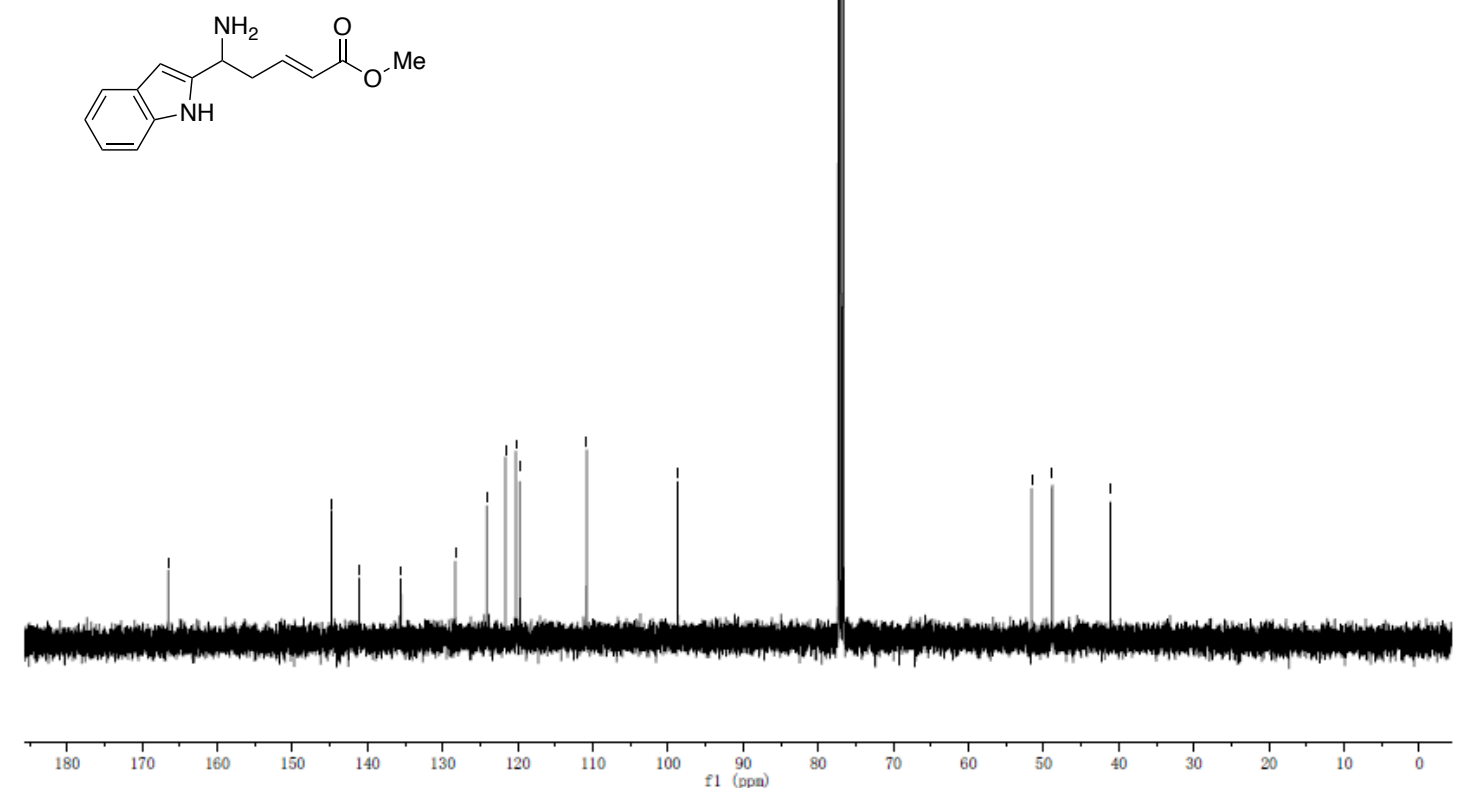

Figure S23. ${ }^{13} \mathrm{C}$ NMR Spectrum of $( \pm)-\mathrm{S} 9\left(\mathrm{CDCl}_{3}, 101 \mathrm{MHz}\right)$ 


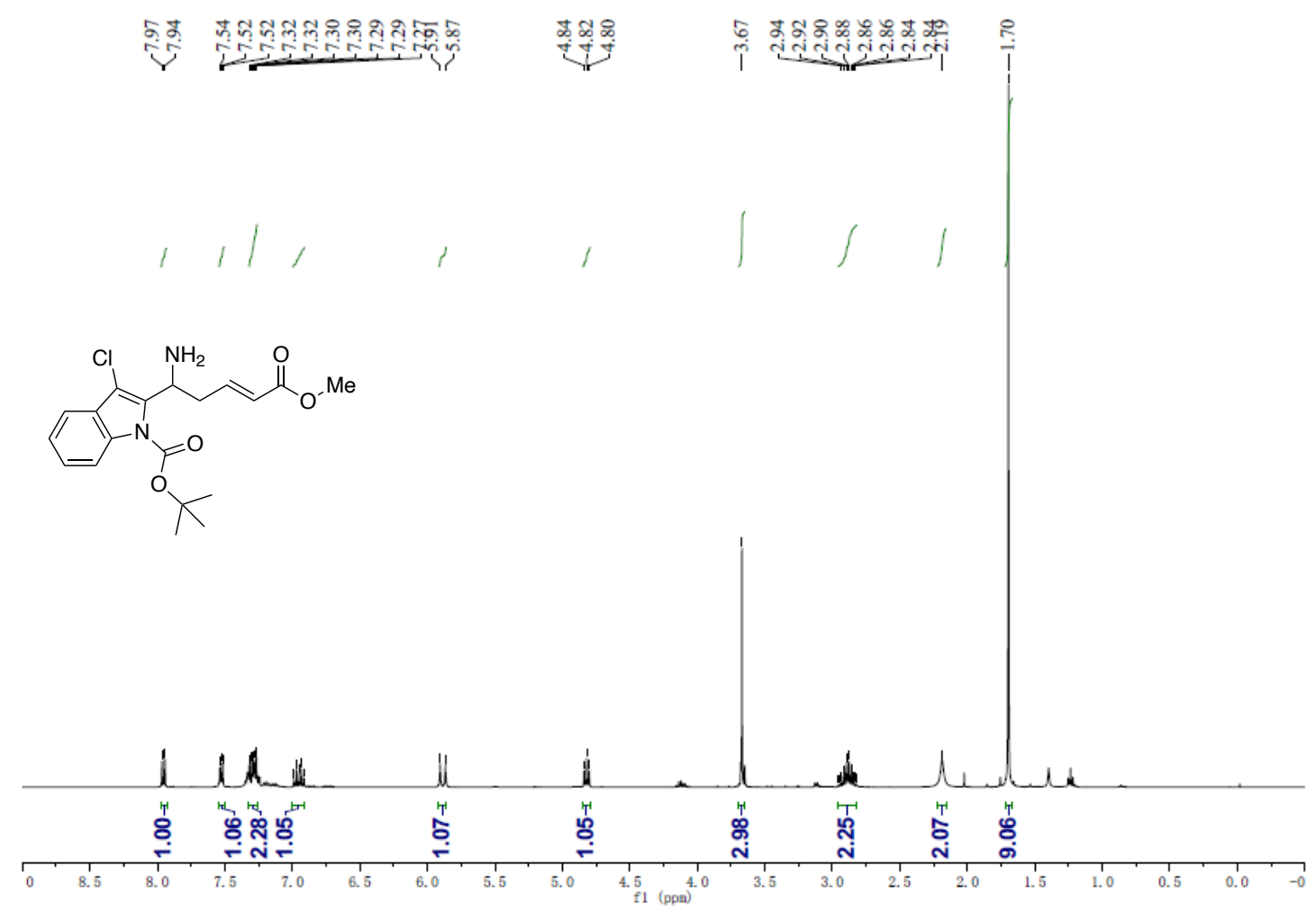

Figure S24. ${ }^{1} \mathrm{H}$ NMR Spectrum of $( \pm)-13 b-1\left(\mathrm{CDCl}_{3}, 400 \mathrm{MHz}\right)$

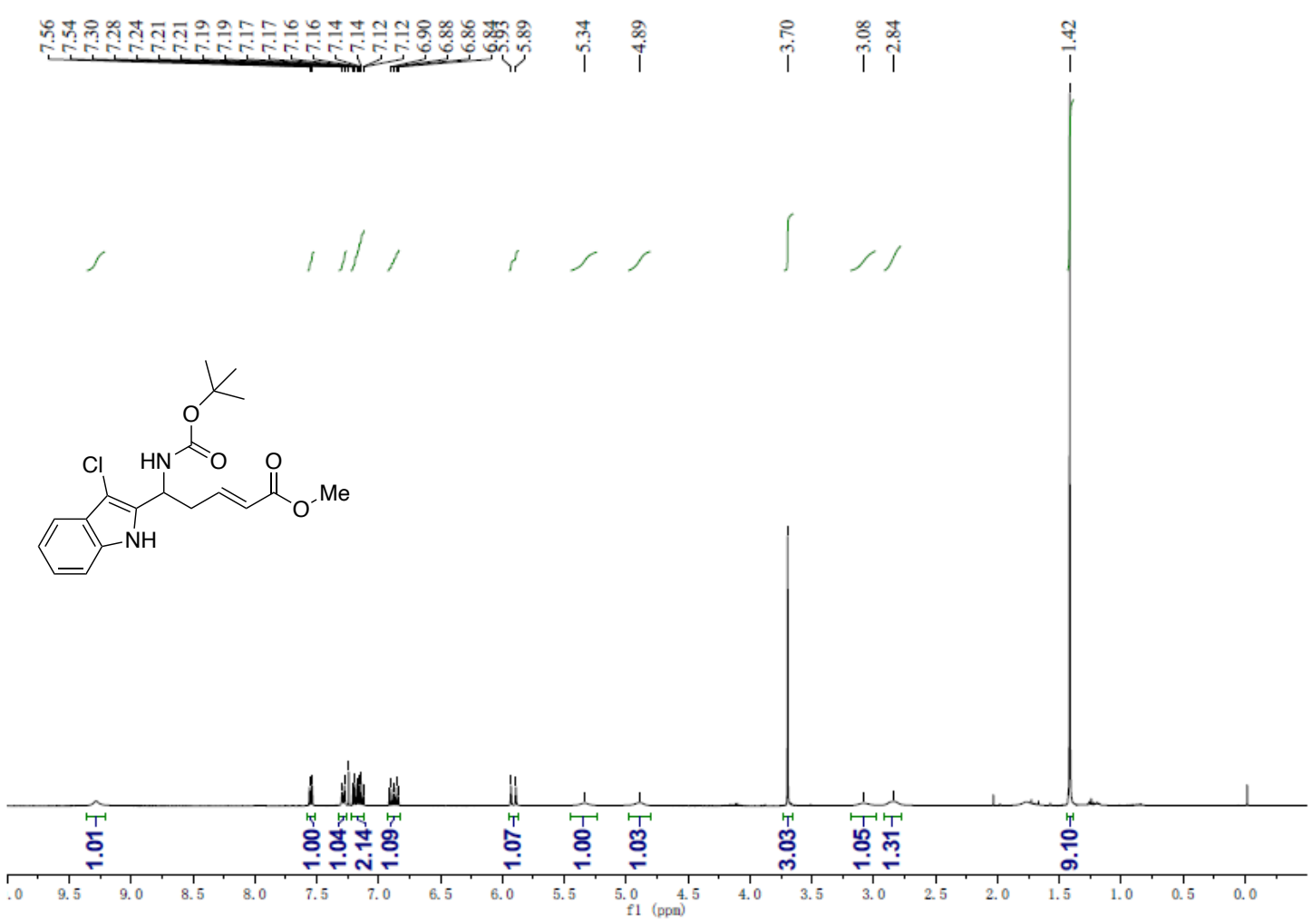

Figure S25. ${ }^{1} \mathrm{H}$ NMR Spectrum of $( \pm)-13 \mathrm{~b}-2\left(\mathrm{CDCl}_{3}, 400 \mathrm{MHz}\right)$ 


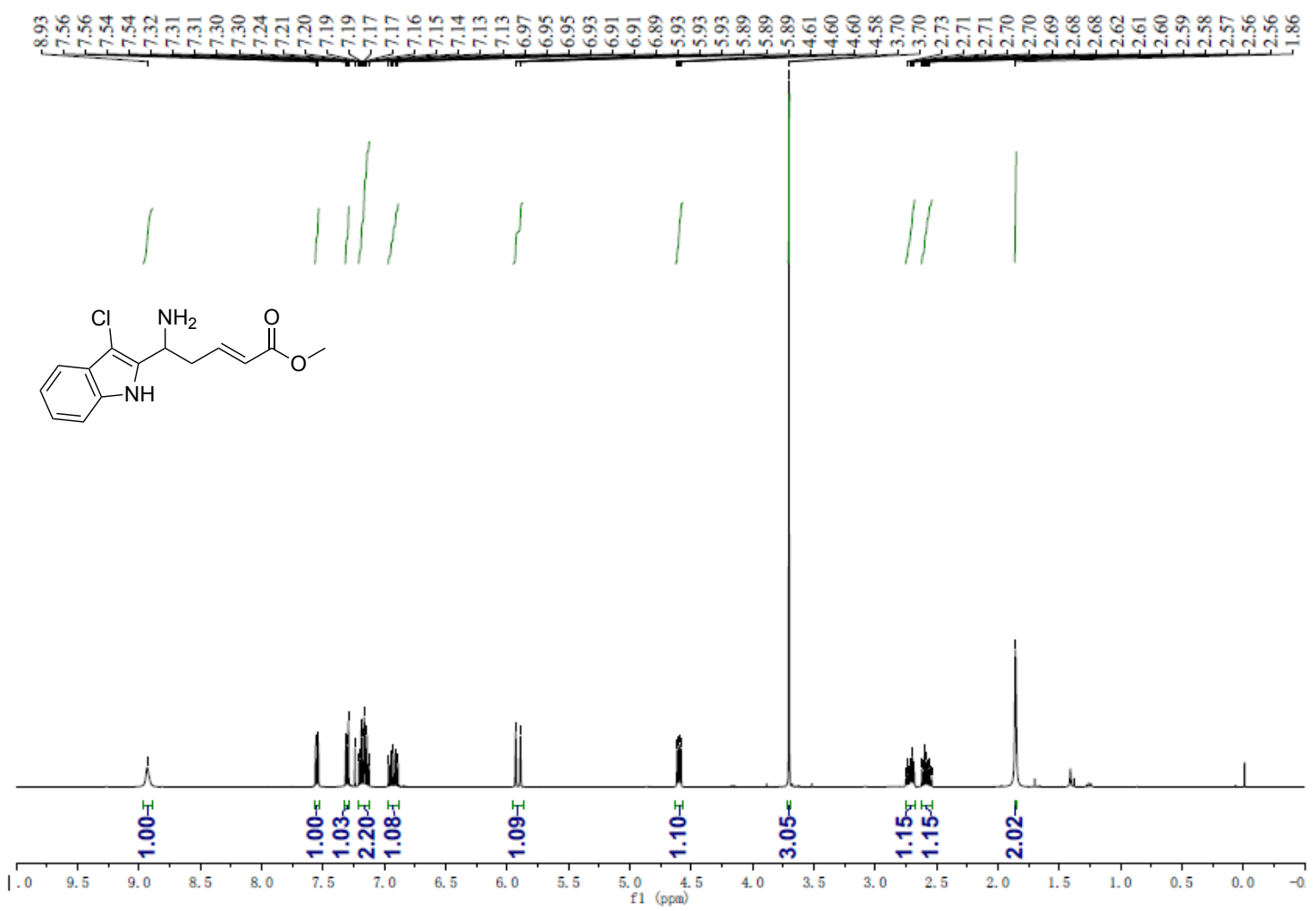

Figure S26. ${ }^{1} \mathrm{H}$ NMR Spectrum of $( \pm)-\mathrm{S} 10\left(\mathrm{CDCl}_{3}, 400 \mathrm{MHz}\right)$
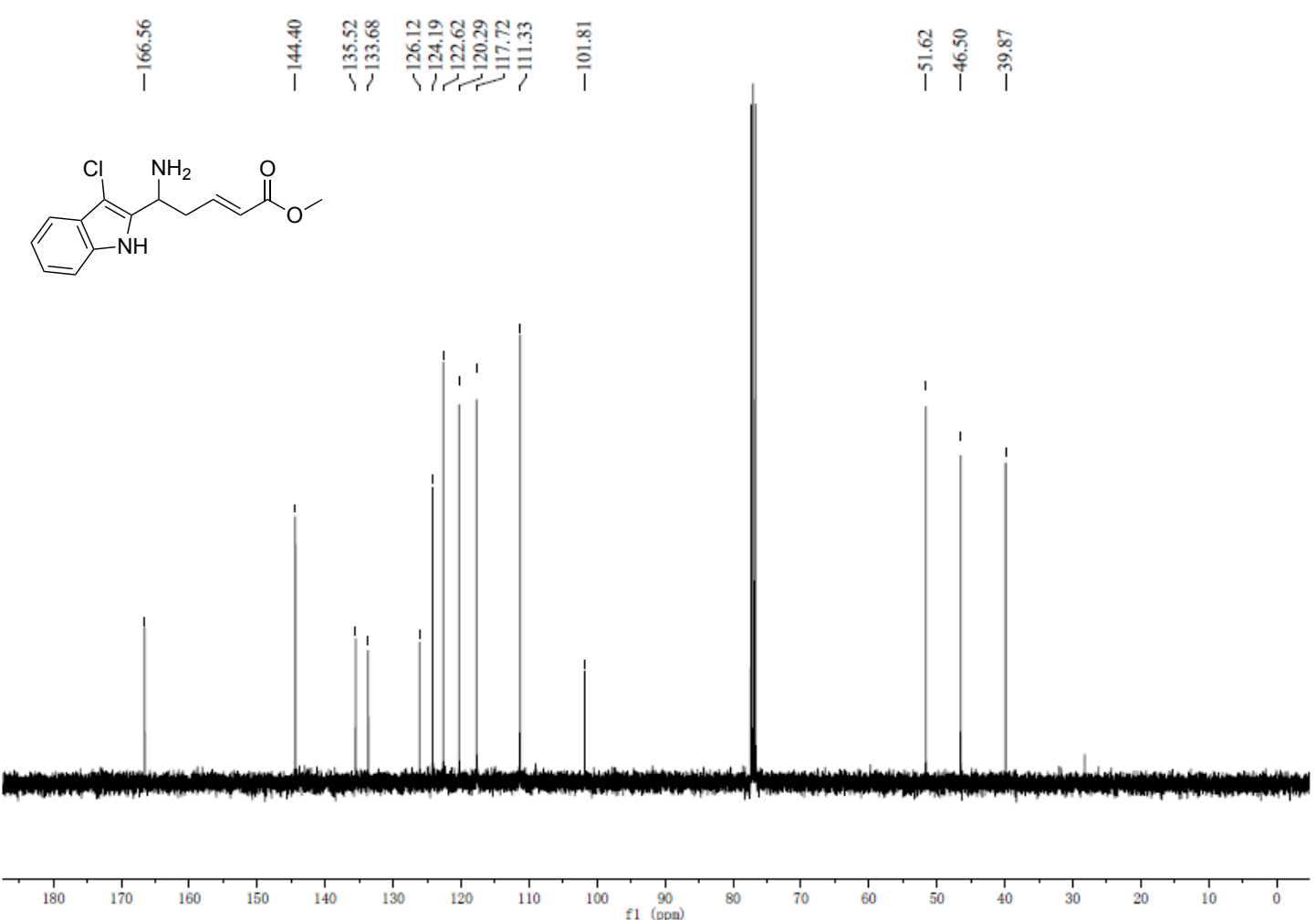

Figure S27. ${ }^{13} \mathrm{C}$ NMR Spectrum of $( \pm)-\mathrm{S10}\left(\mathrm{CDCl}_{3}, 101 \mathrm{MHz}\right)$ 


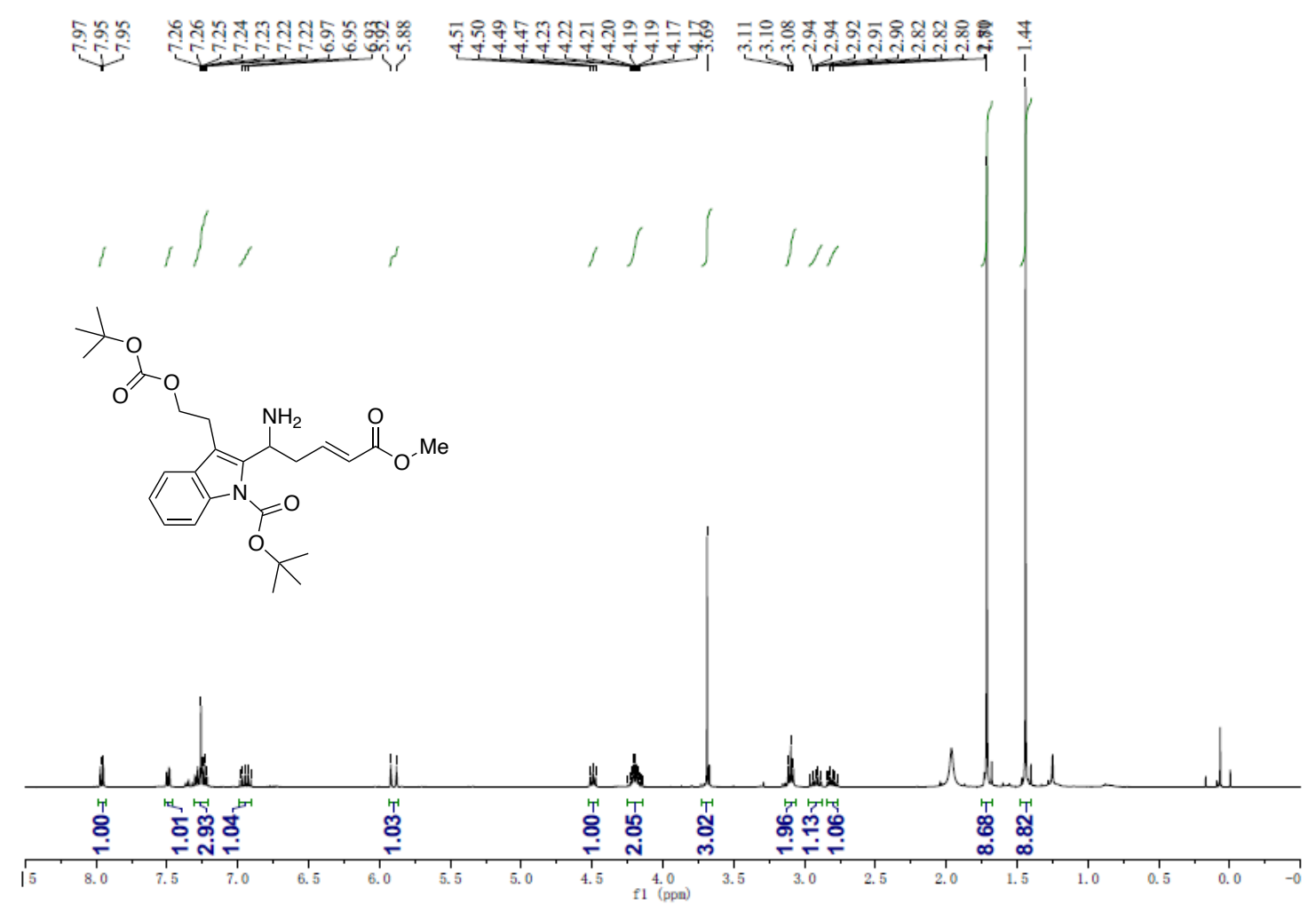

Figure S28. ${ }^{1} \mathrm{H}$ NMR Spectrum of $( \pm)-13 \mathrm{c}\left(\mathrm{CDCl}_{3}, 400 \mathrm{MHz}\right)$
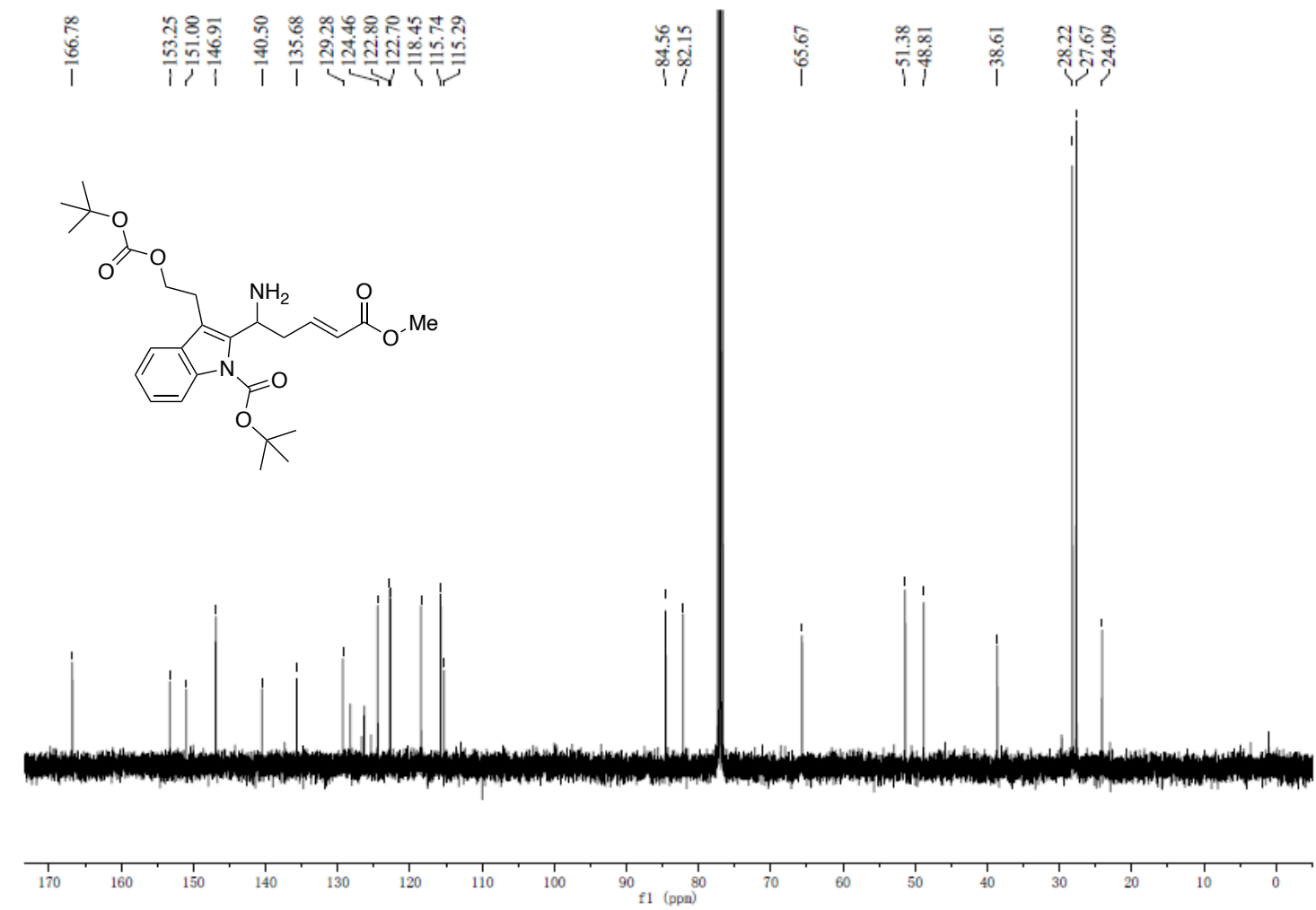

Figure S29. ${ }^{13} \mathrm{C}$ NMR Spectrum of $( \pm)-13 \mathrm{c}\left(\mathrm{CDCl}_{3}, 101 \mathrm{MHz}\right)$ 


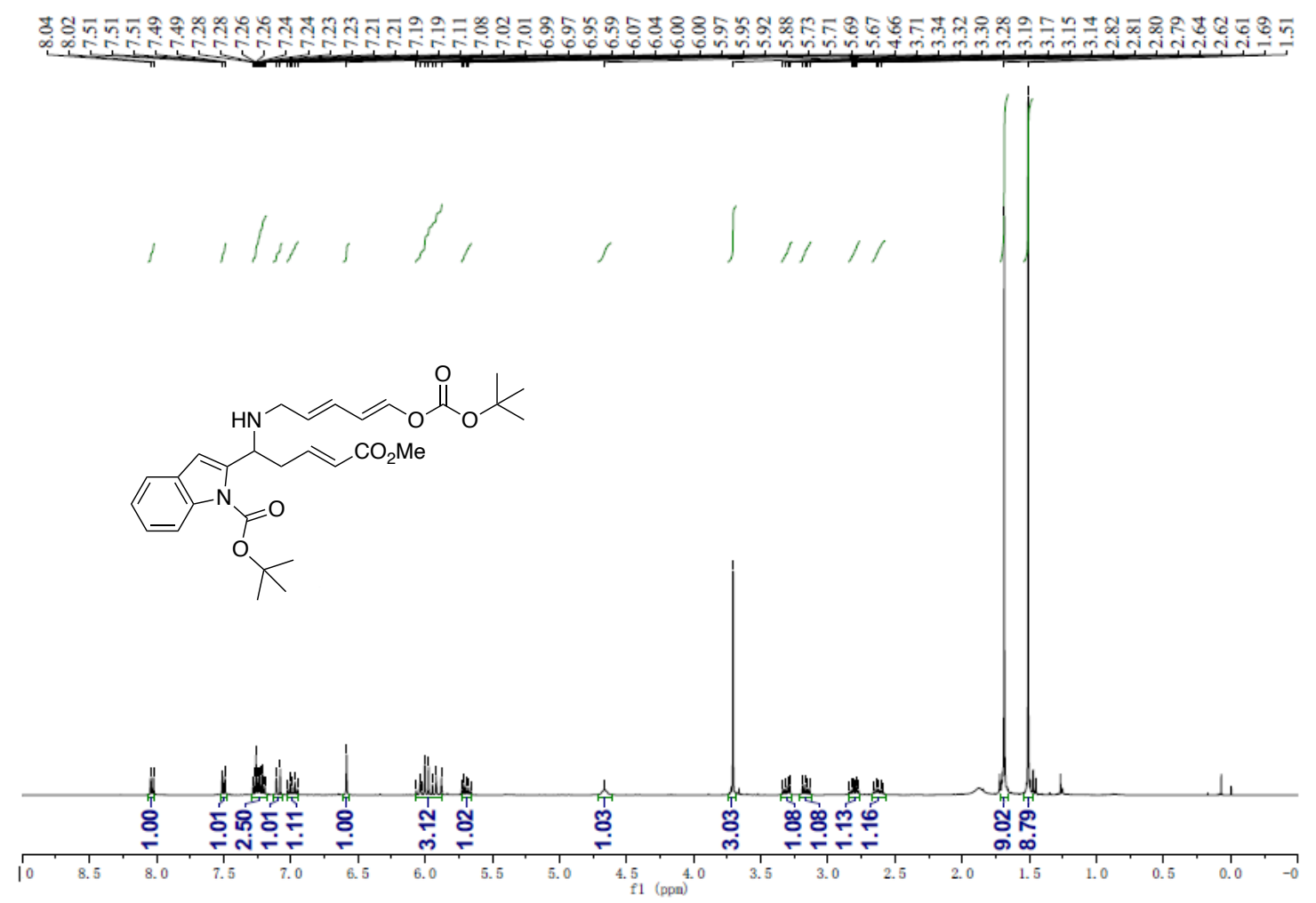

Figure S30. ${ }^{1} \mathrm{H}$ NMR Spectrum of $( \pm)-4 a\left(\mathrm{CDCl}_{3}, 400 \mathrm{MHz}\right)$

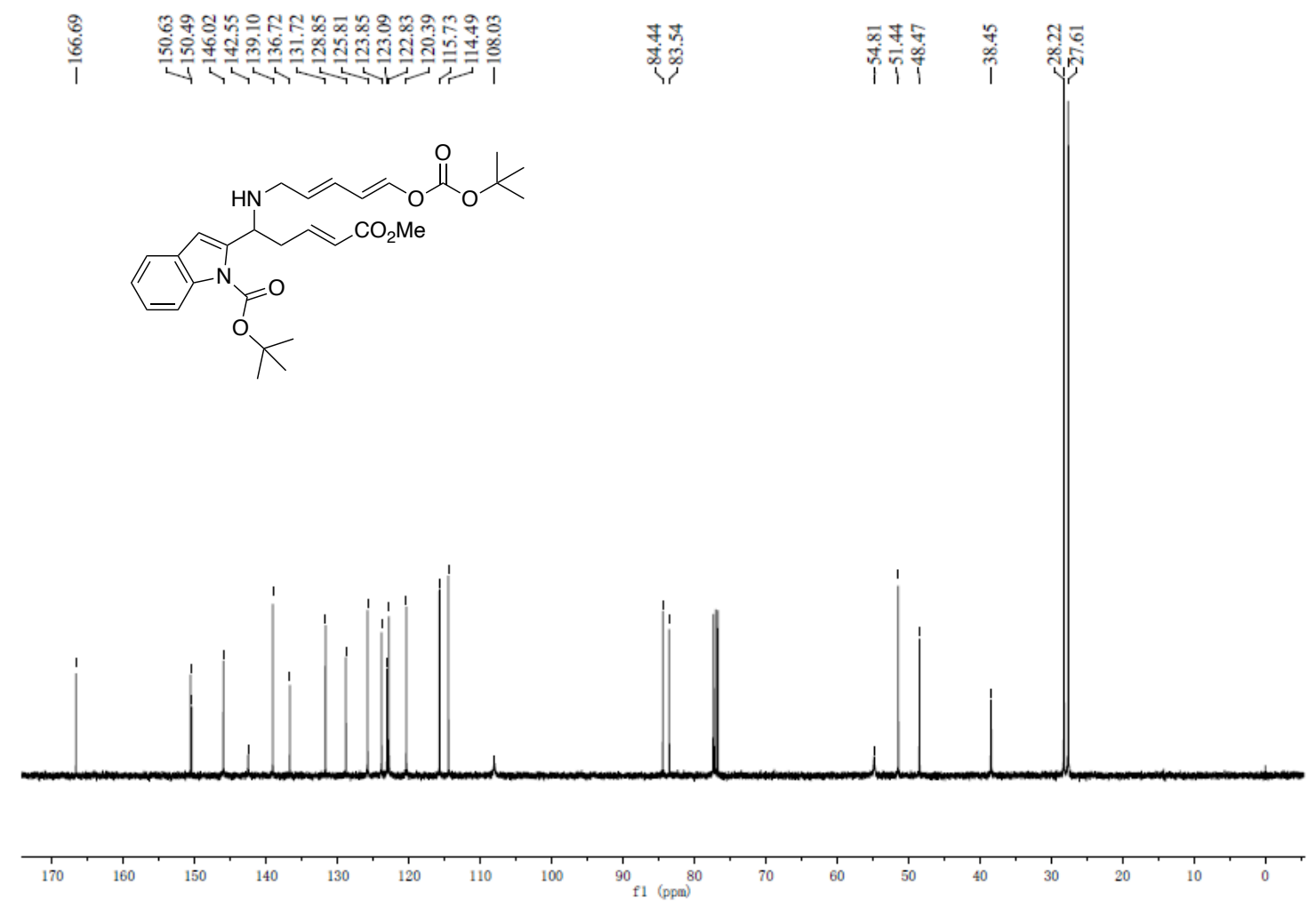

Figure S31. ${ }^{13} \mathrm{C}$ NMR Spectrum of $( \pm)-4 a\left(\mathrm{CDCl}_{3}, 101 \mathrm{MHz}\right)$ 


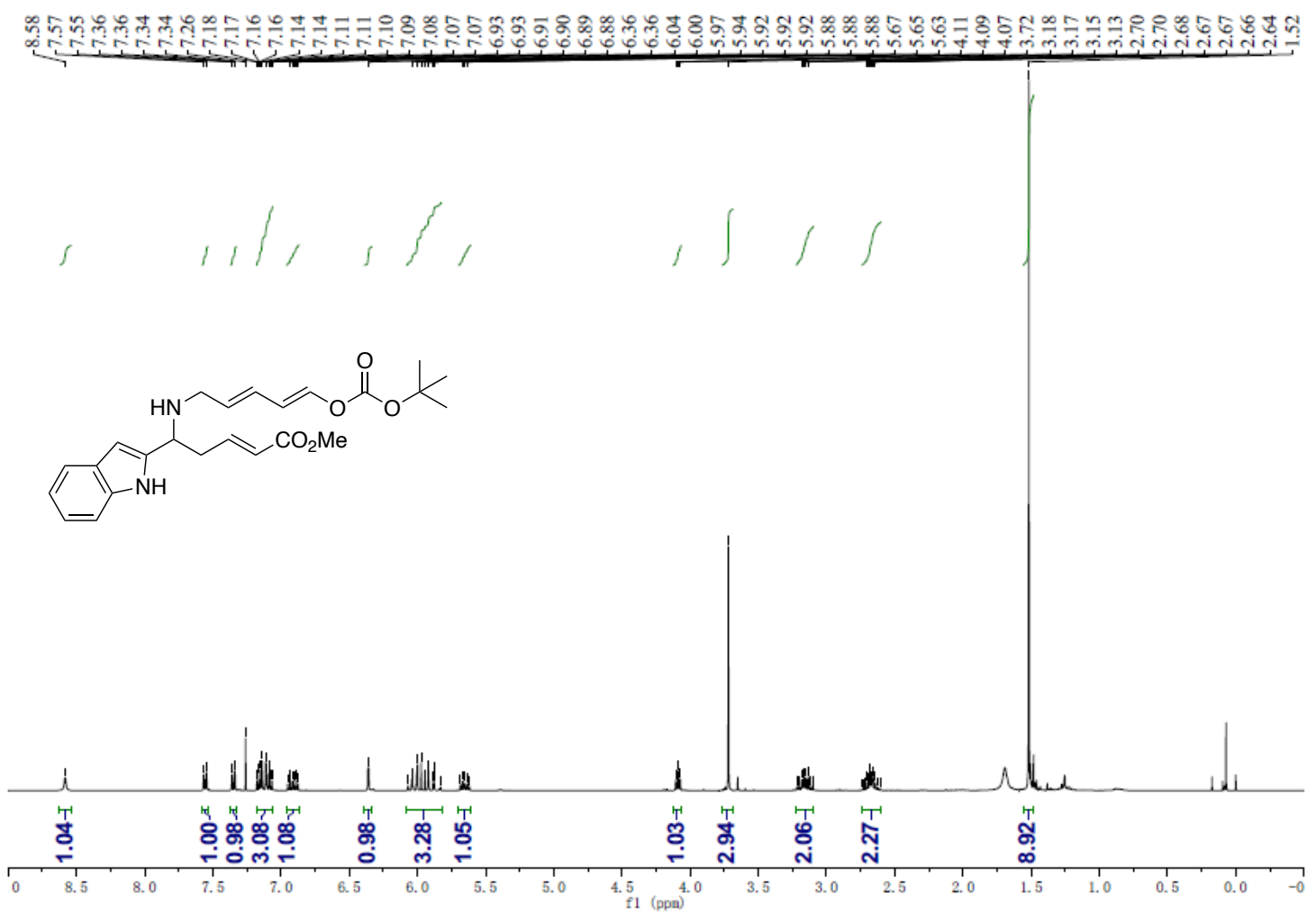

Figure S32. ${ }^{1} \mathrm{H}$ NMR Spectrum of $( \pm)-4 a^{\prime}\left(\mathrm{CDCl}_{3}, 400 \mathrm{MHz}\right)$

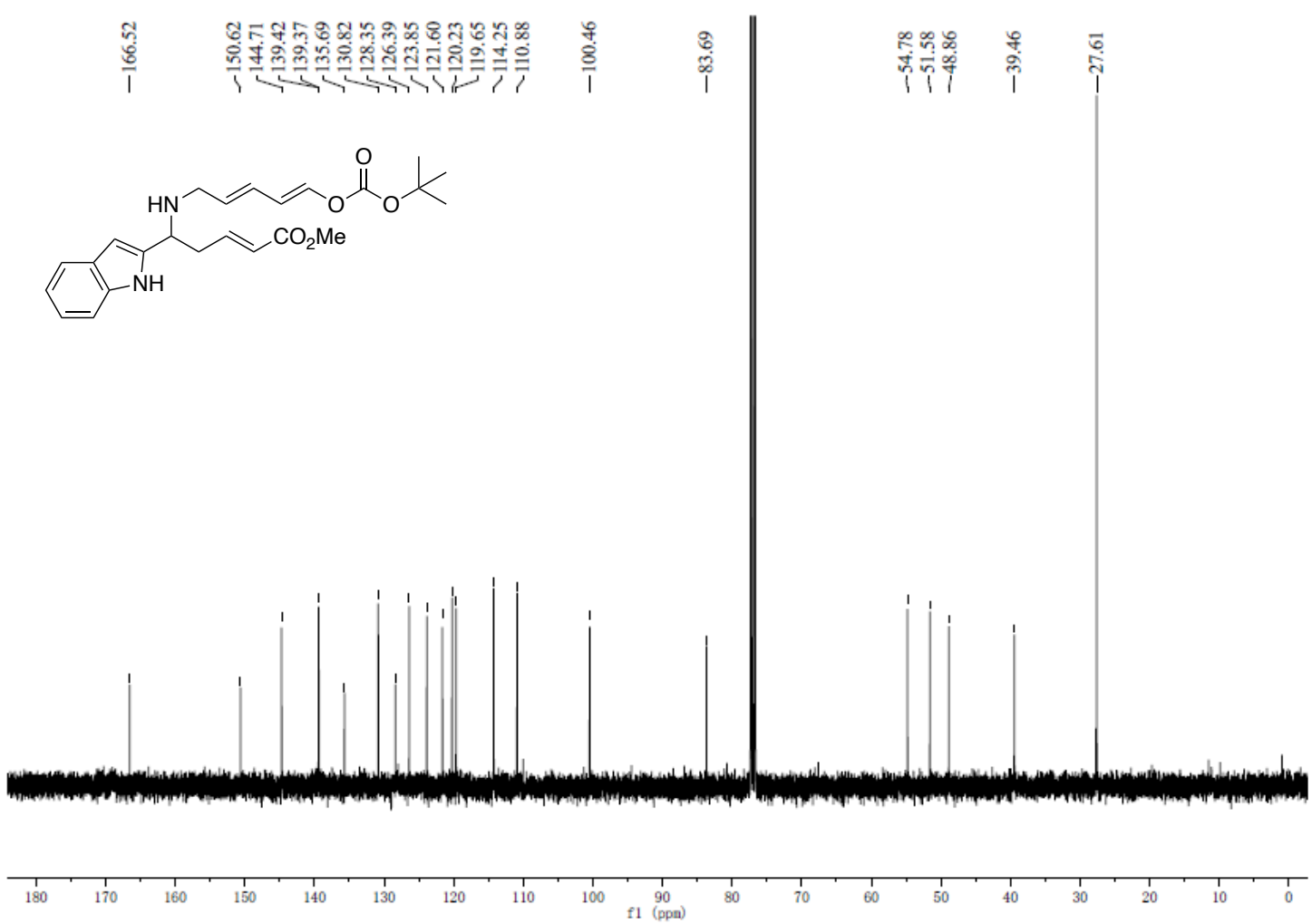

Figure S33. ${ }^{13} \mathrm{C}$ NMR Spectrum of $( \pm)-4 a '\left(\mathrm{CDCl}_{3}, 101 \mathrm{MHz}\right)$ 


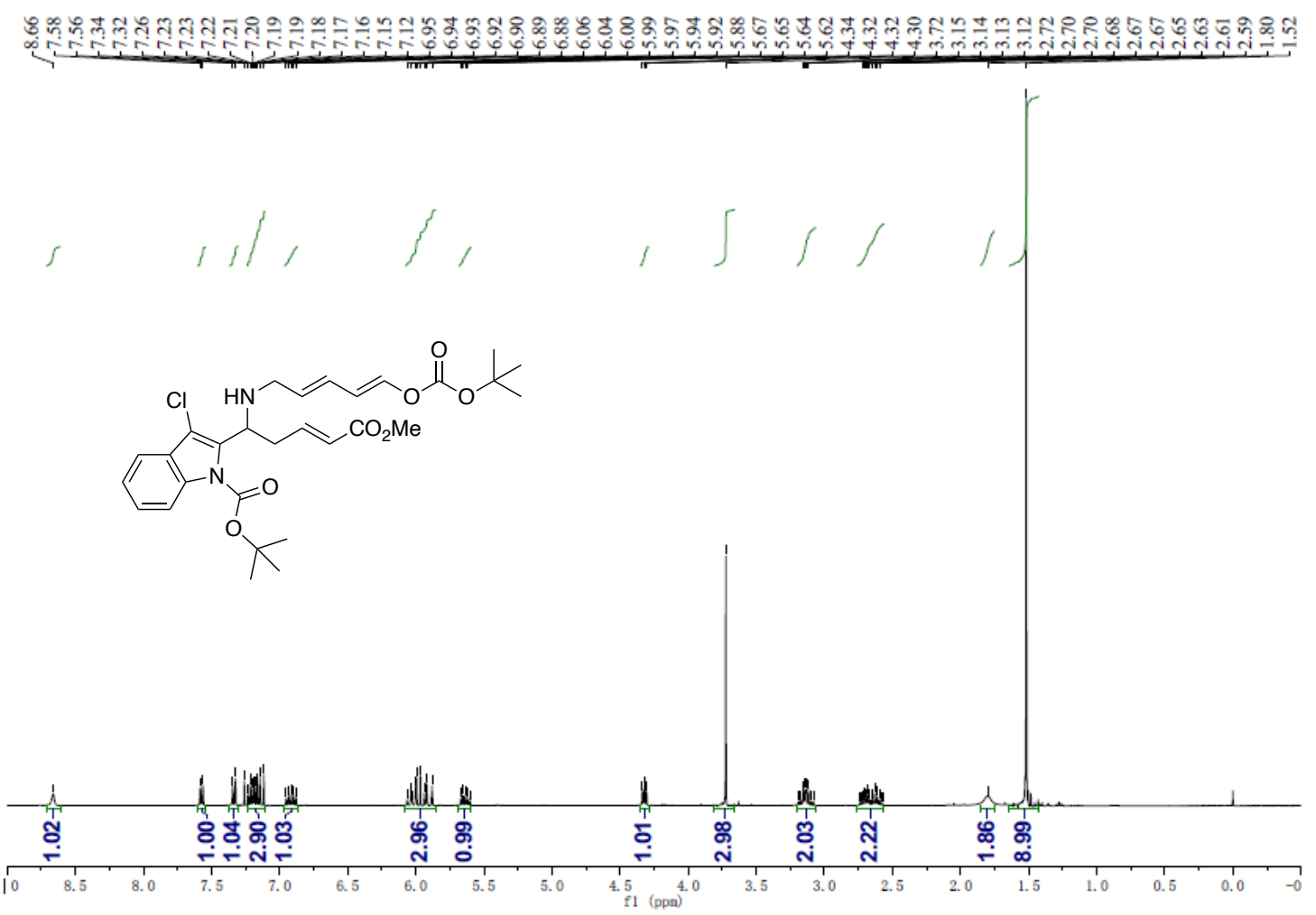

Figure S34. ${ }^{1} \mathrm{H}$ NMR Spectrum of $( \pm)-4 \mathrm{~b}\left(\mathrm{CDCl}_{3}, 400 \mathrm{MHz}\right)$

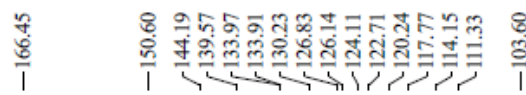

$\underset{8}{8}$

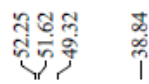
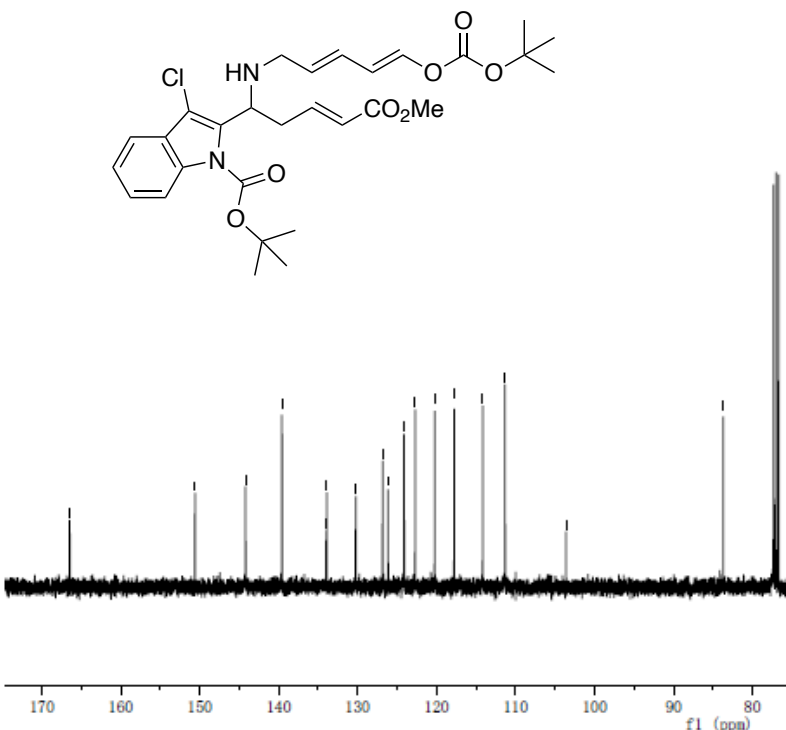

Figure S35. ${ }^{13} \mathrm{C}$ NMR Spectrum of $( \pm)-4 \mathrm{~b}\left(\mathrm{CDCl}_{3}, 101 \mathrm{MHz}\right)$ 


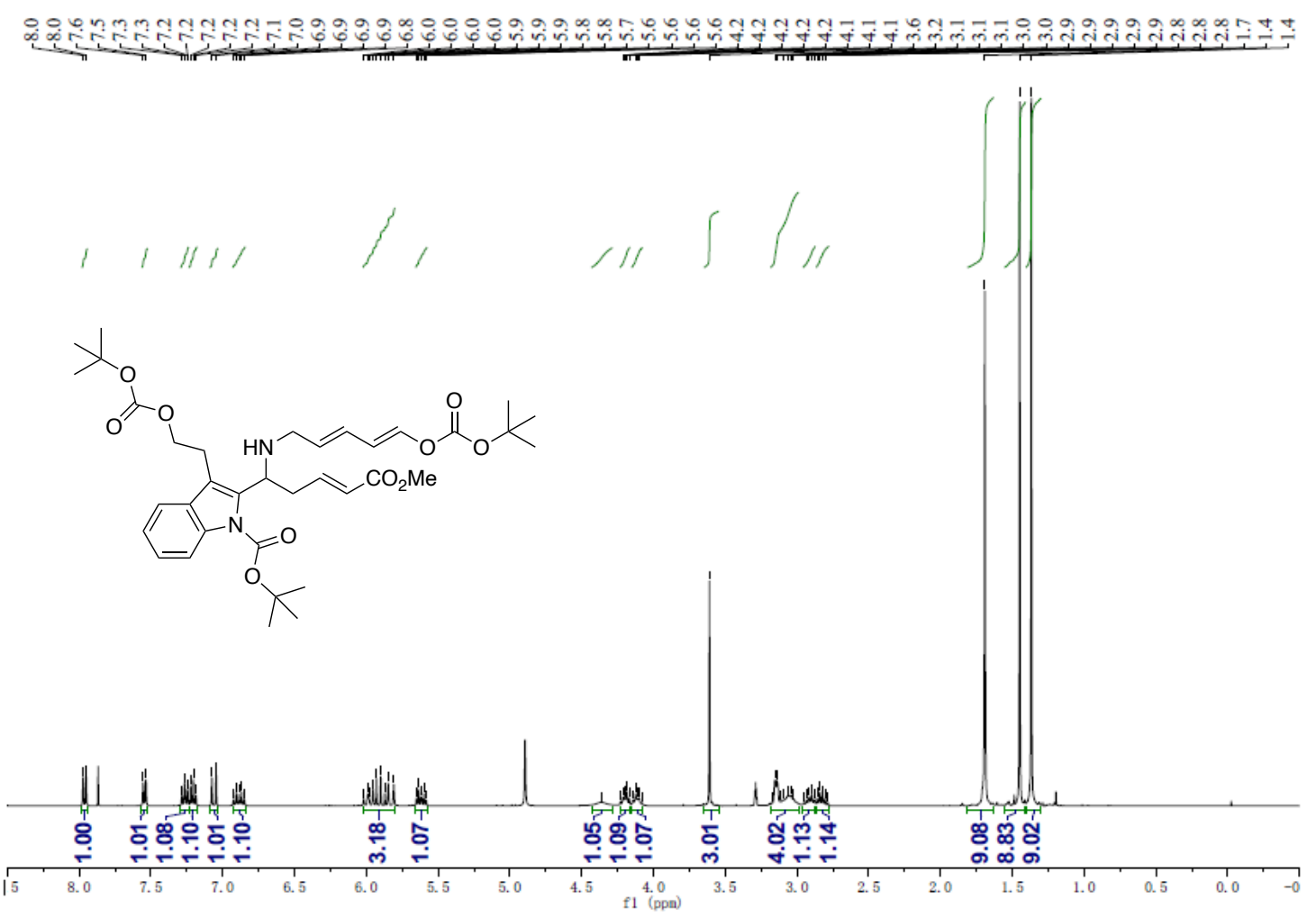

Figure S36. ${ }^{1} \mathrm{H}$ NMR Spectrum of $( \pm)-4 \mathrm{c}\left(\mathrm{CD}_{3} \mathrm{OD}, 400 \mathrm{MHz}\right)$
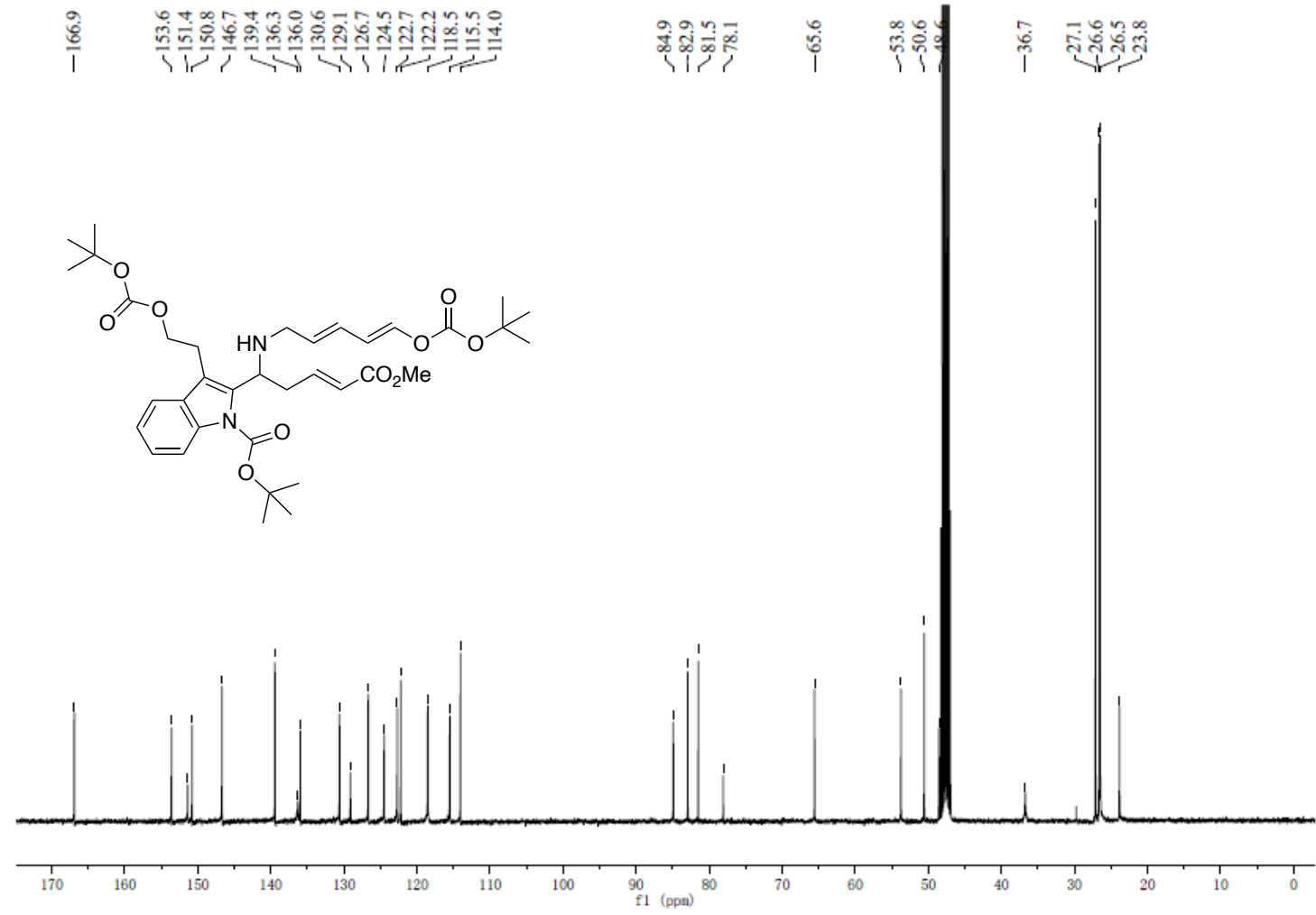

Figure S37. ${ }^{13} \mathrm{C}$ NMR Spectrum of $( \pm)-4 \mathrm{c}\left(\mathrm{CD}_{3} \mathrm{OD}, 101 \mathrm{MHz}\right)$ 


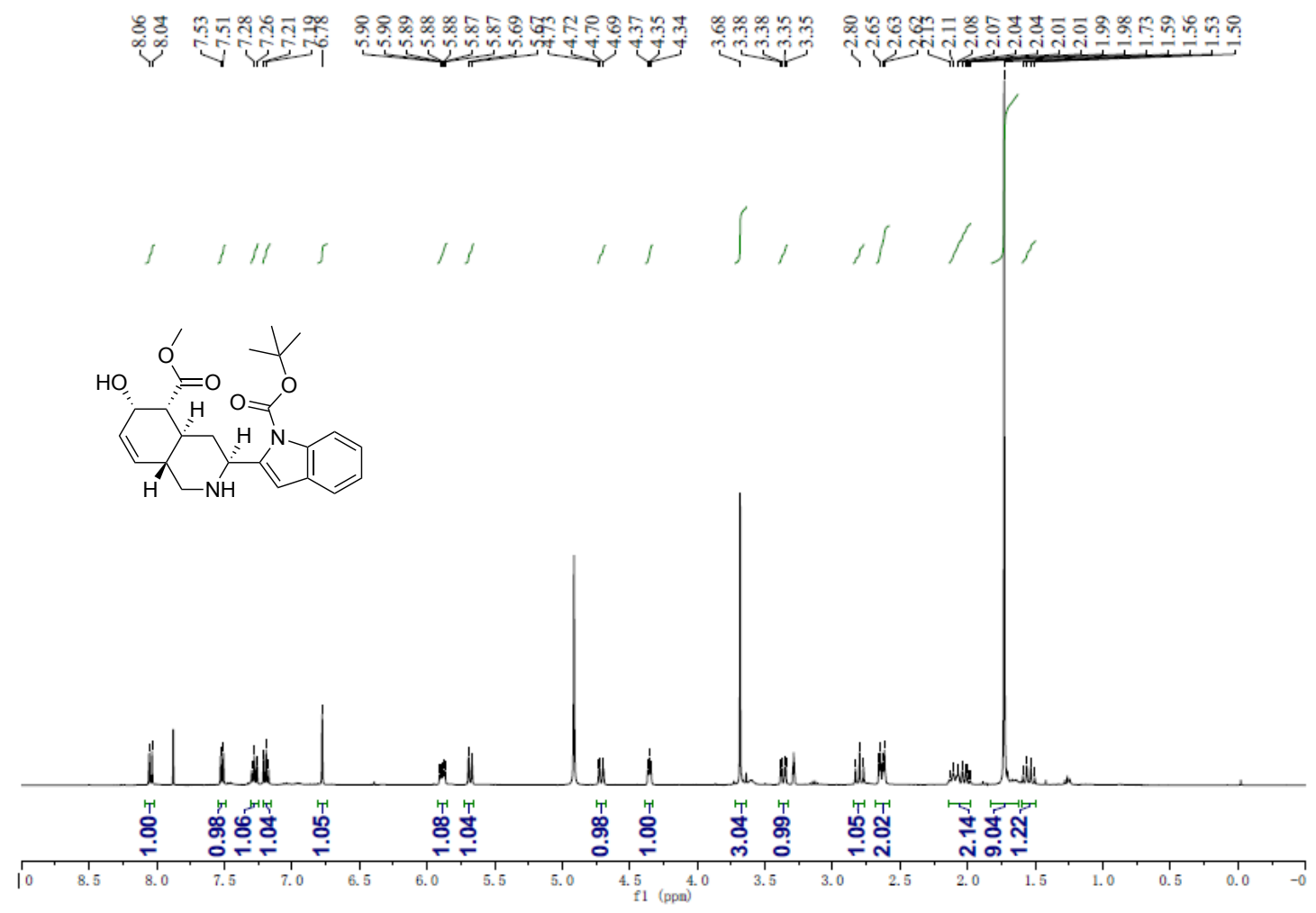

Figure S38. ${ }^{1} \mathrm{H}$ NMR Spectrum of $( \pm)-15 \mathrm{a}\left(\mathrm{CD}_{3} \mathrm{OD}, 400 \mathrm{MHz}\right)$
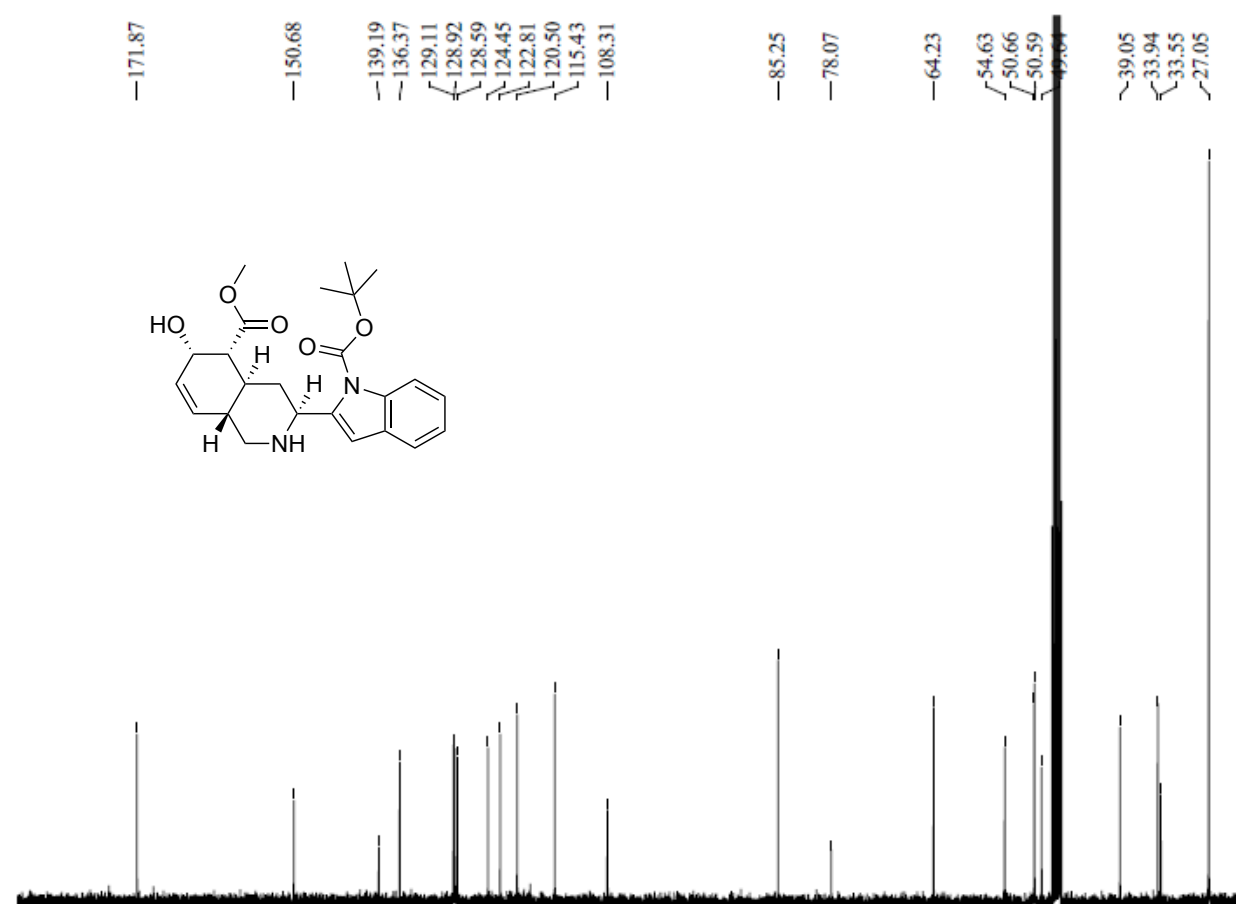


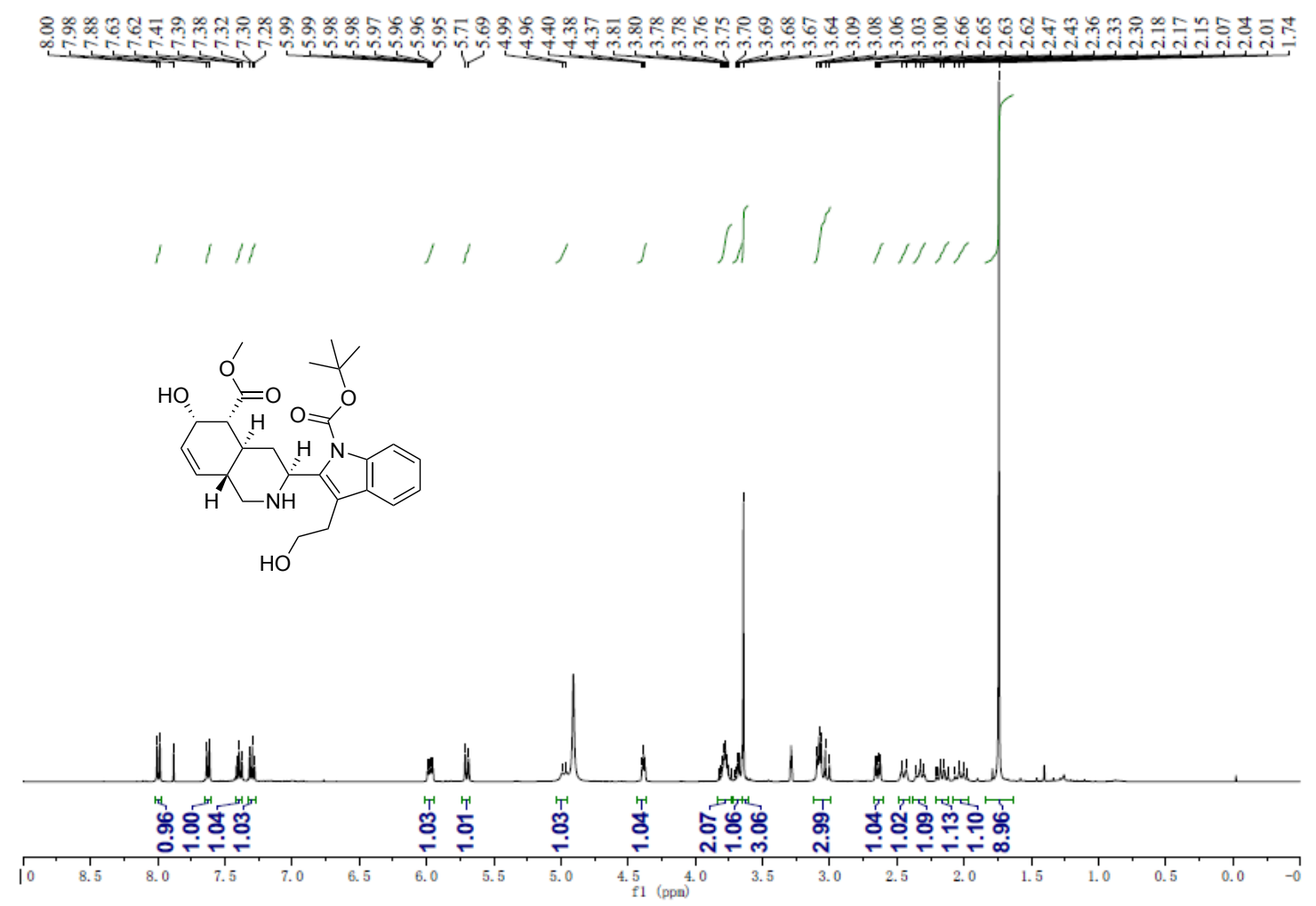

Figure S40. ${ }^{1} \mathrm{H}$ NMR Spectrum of $( \pm)-15 b\left(\mathrm{CD}_{3} \mathrm{OD}, 400 \mathrm{MHz}\right)$

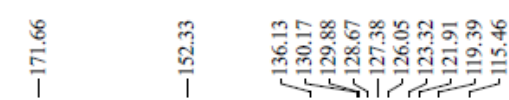

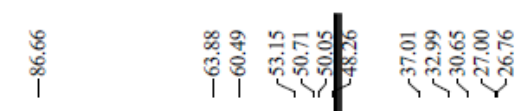
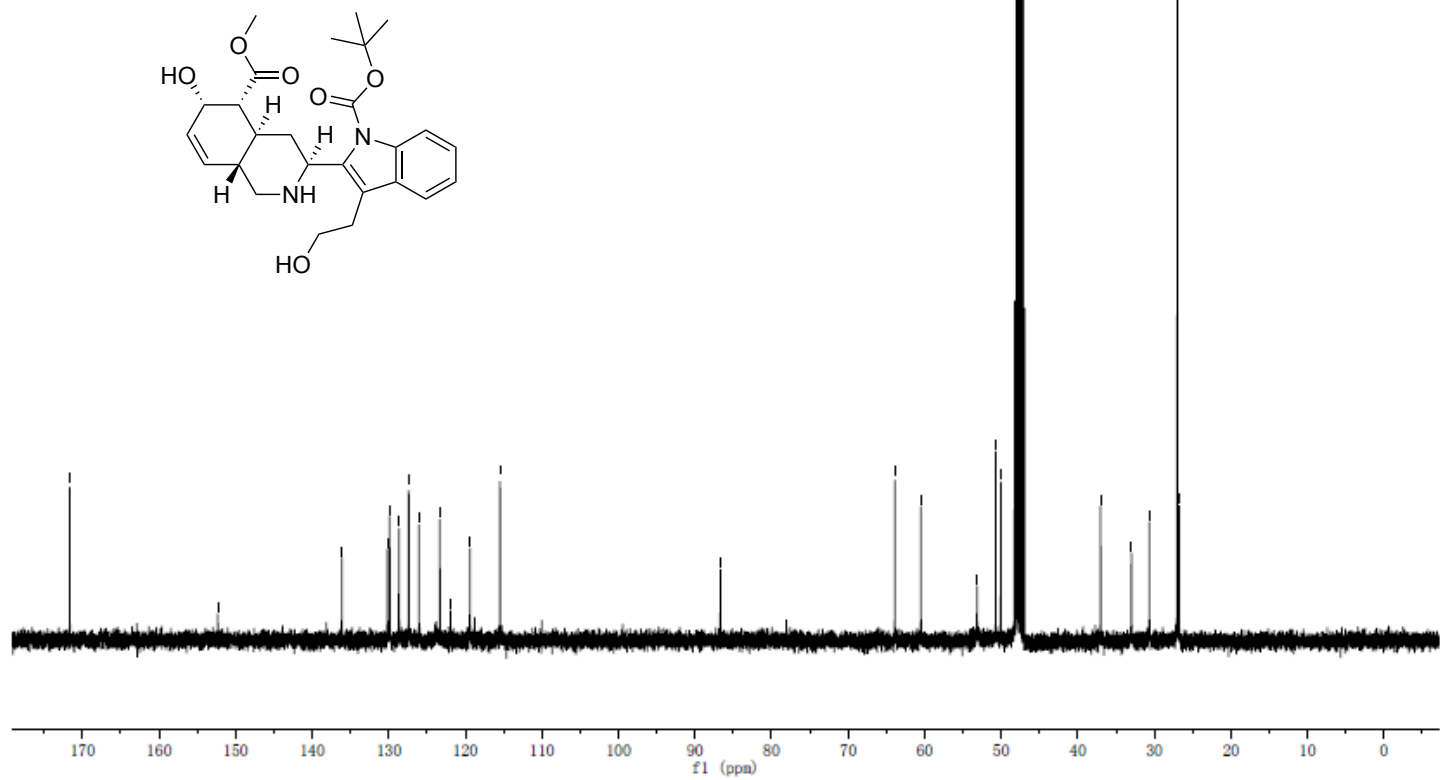

Figure S41. ${ }^{13} \mathrm{C}$ NMR Spectrum of $( \pm)-15 b\left(\mathrm{CD}_{3} \mathrm{OD}, 101 \mathrm{MHz}\right)$ 


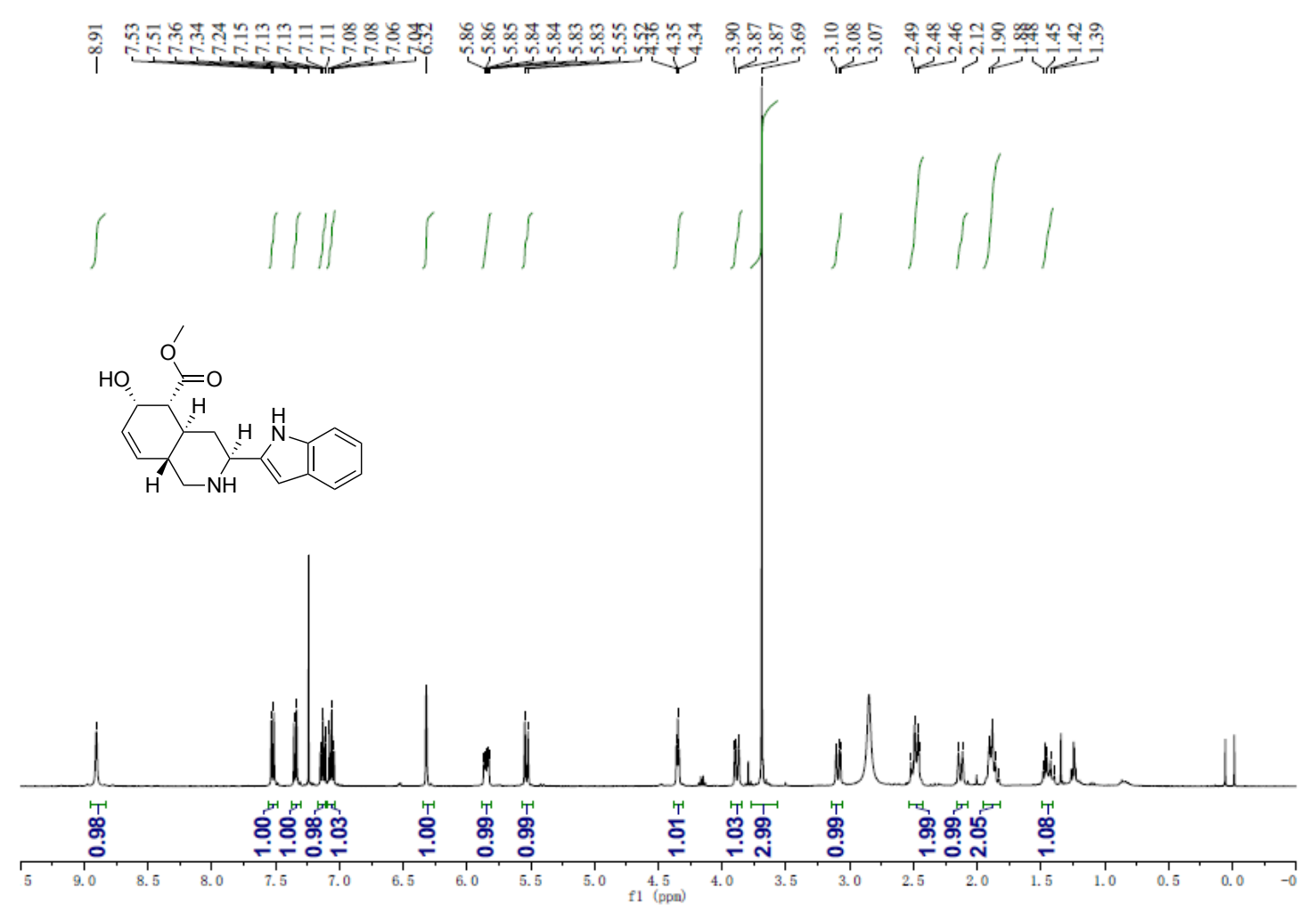

Figure S42. ${ }^{1} \mathrm{H}$ NMR Spectrum of $( \pm)-16 a\left(\mathrm{CDCl}_{3}, 400 \mathrm{MHz}\right)$
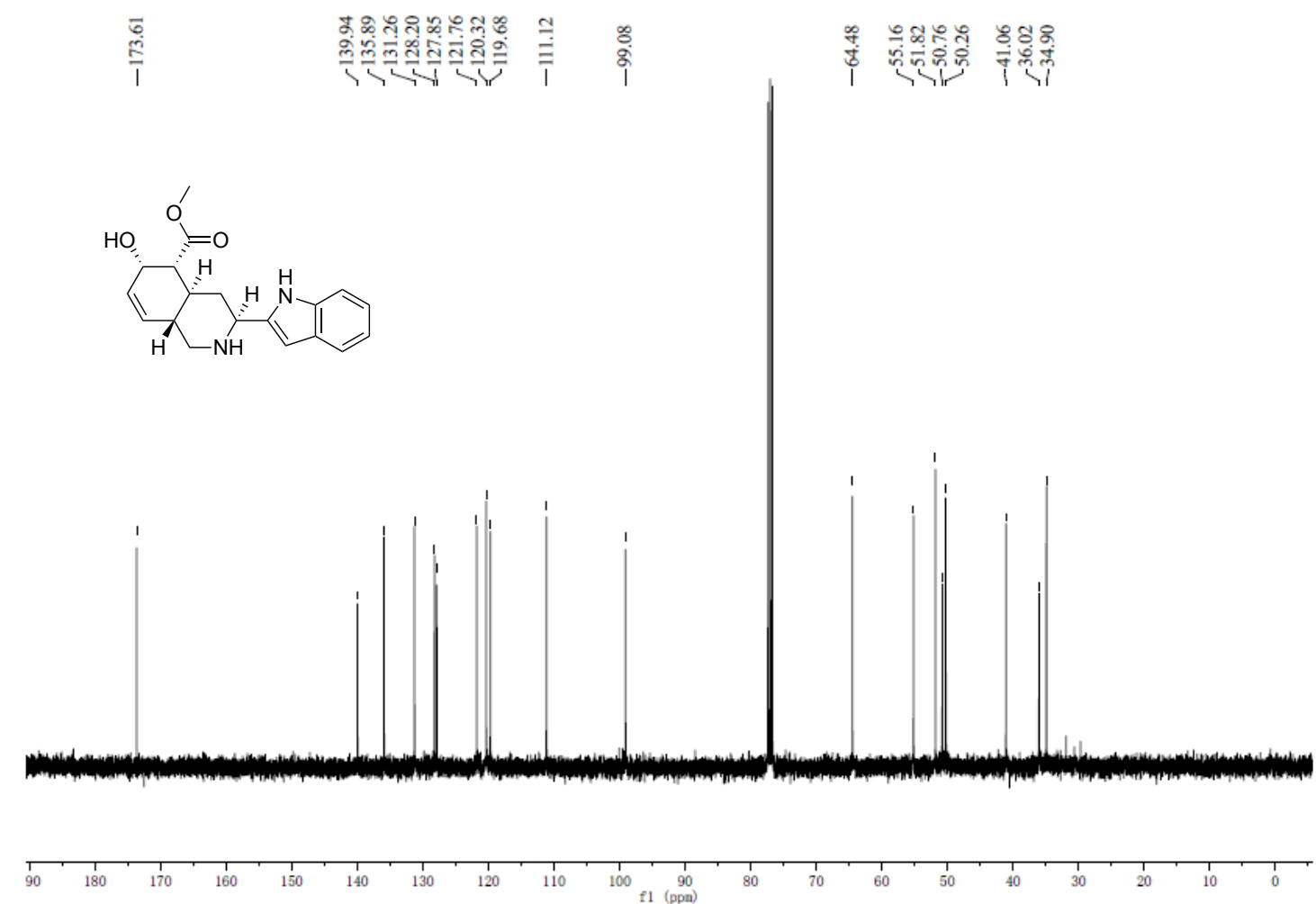

Figure S43. ${ }^{13} \mathrm{C}$ NMR Spectrum of $( \pm)-16$ a $\left(\mathrm{CDCl}_{3}, 101 \mathrm{MHz}\right)$ 


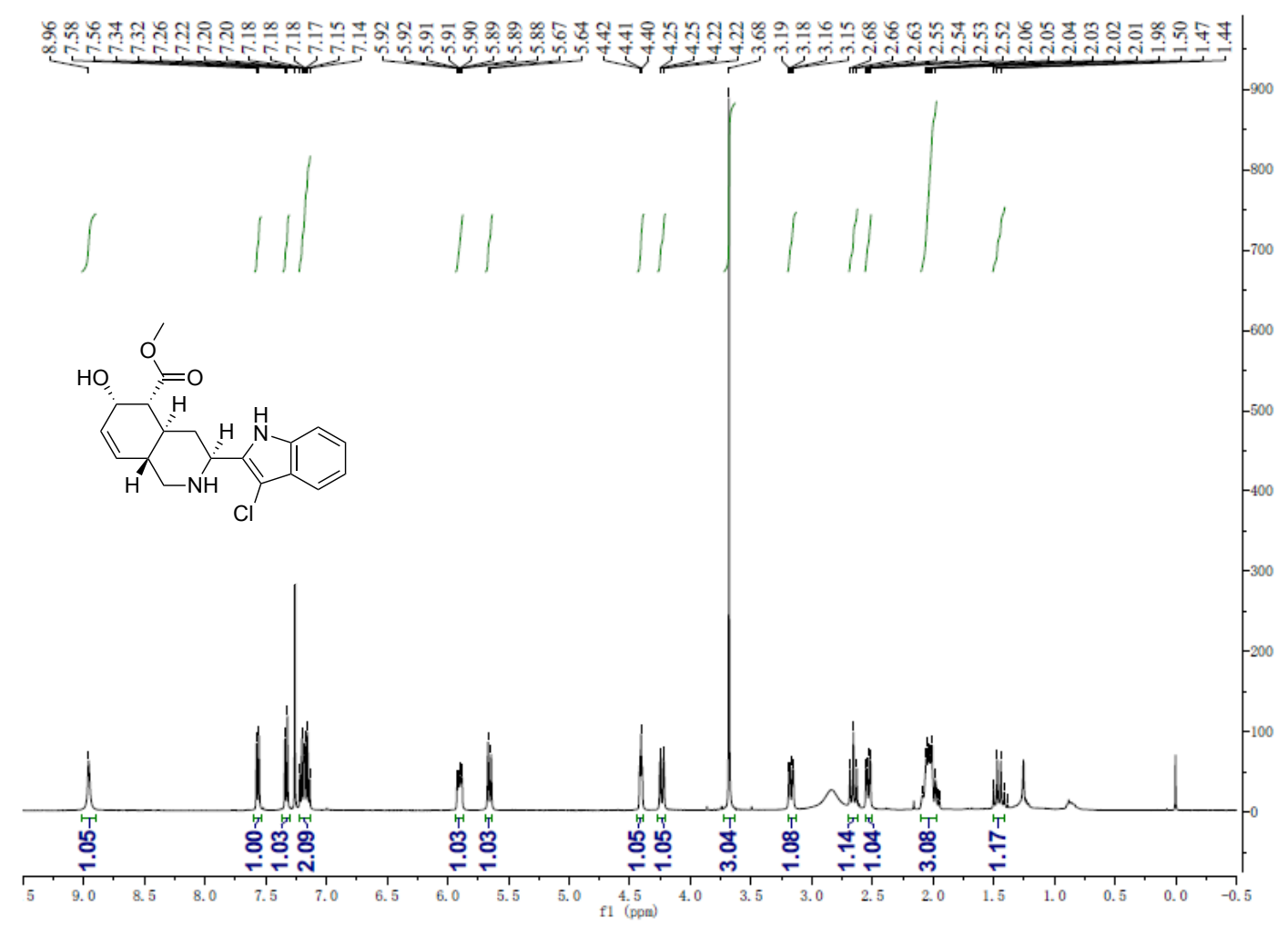

Figure S44. ${ }^{1} \mathrm{H}$ NMR Spectrum of $( \pm)-16 \mathrm{~b}\left(\mathrm{CDCl}_{3}, 400 \mathrm{MHz}\right)$

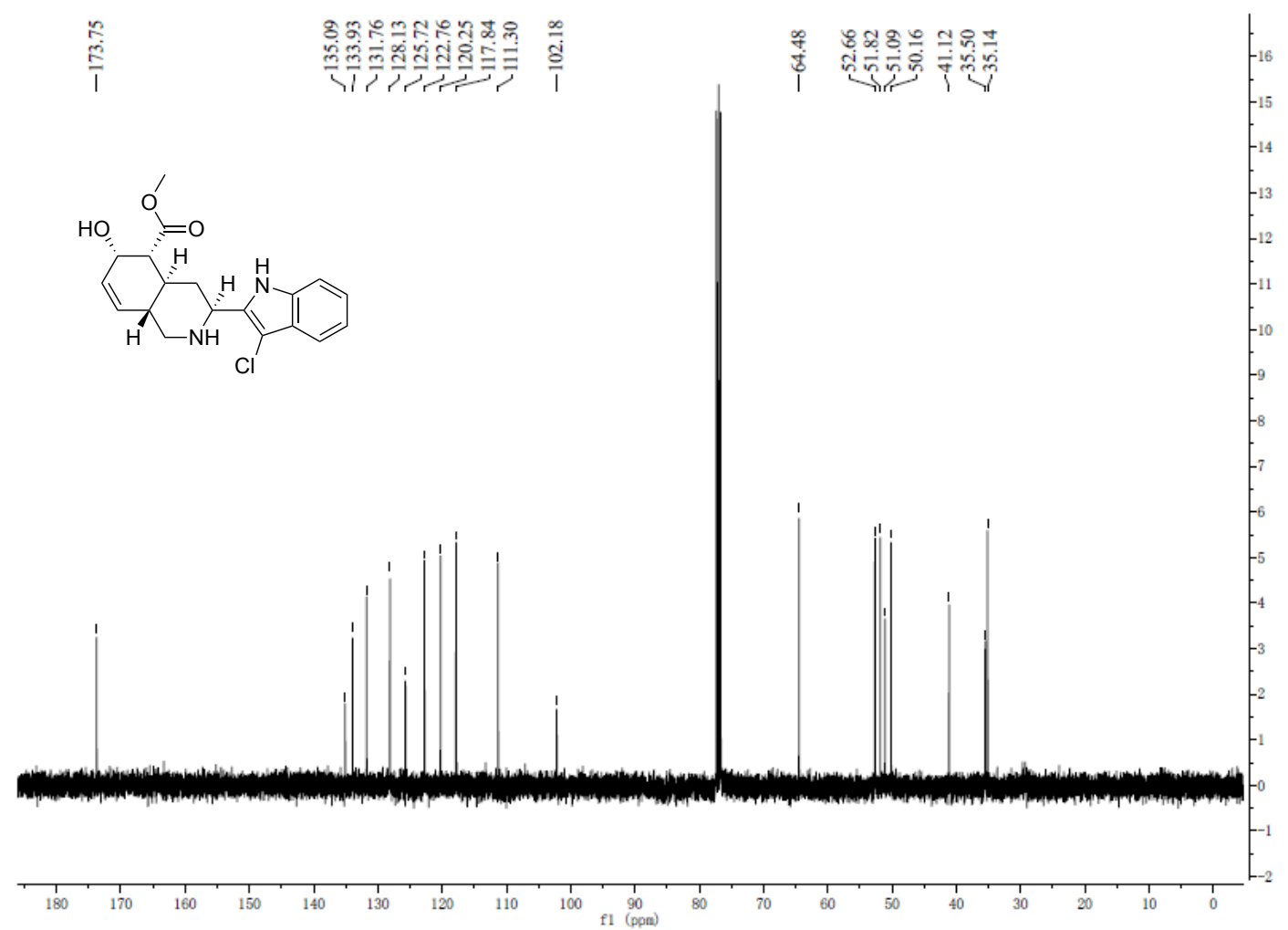

Figure S45. ${ }^{13} \mathrm{C}$ NMR Spectrum of $( \pm)-16 \mathrm{~b}\left(\mathrm{CDCl}_{3}, 101 \mathrm{MHz}\right)$ 


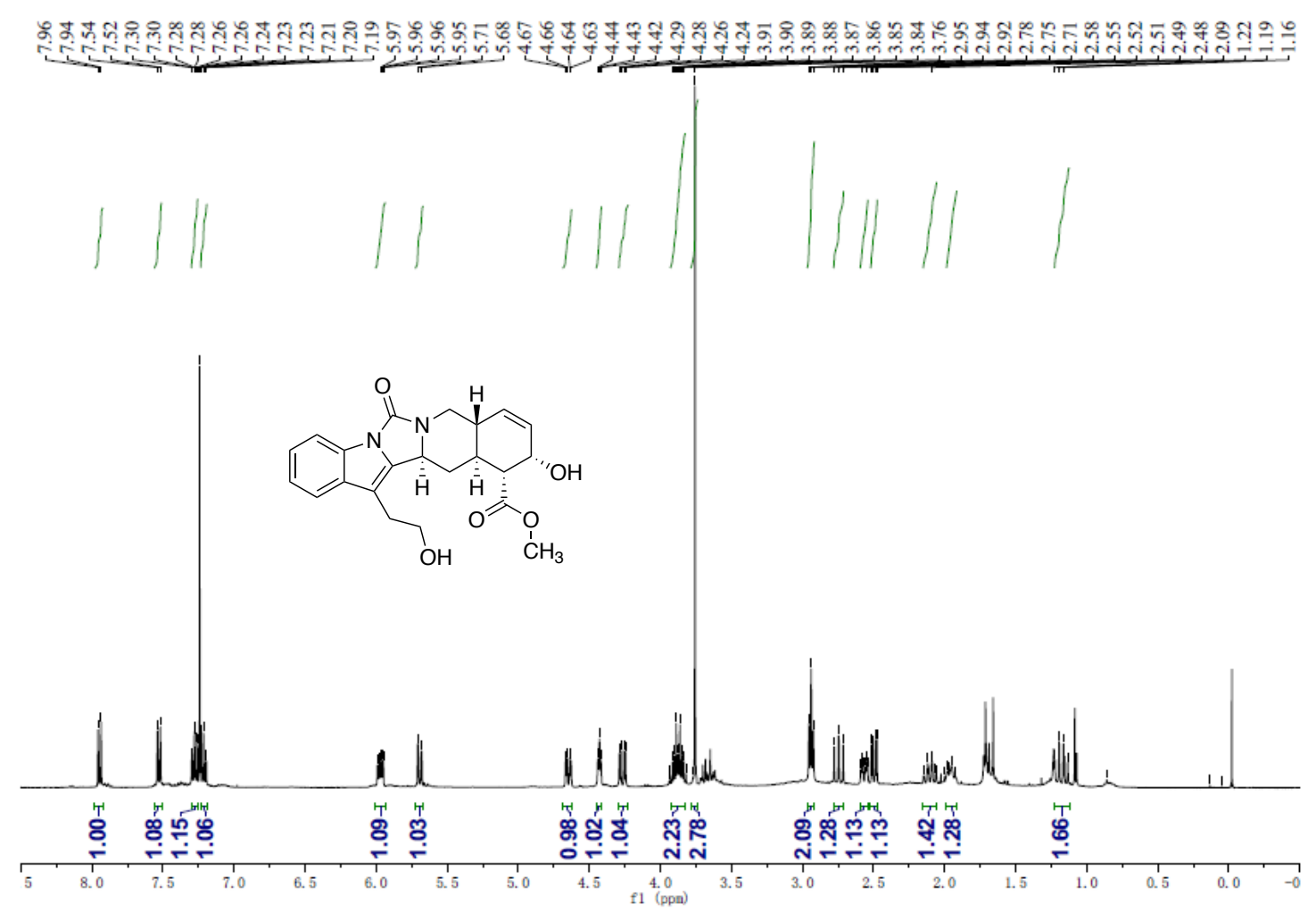

Figure S46. ${ }^{1} \mathrm{H}$ NMR Spectrum of $( \pm)-17\left(\mathrm{CDCl}_{3}, 400 \mathrm{MHz}\right)$
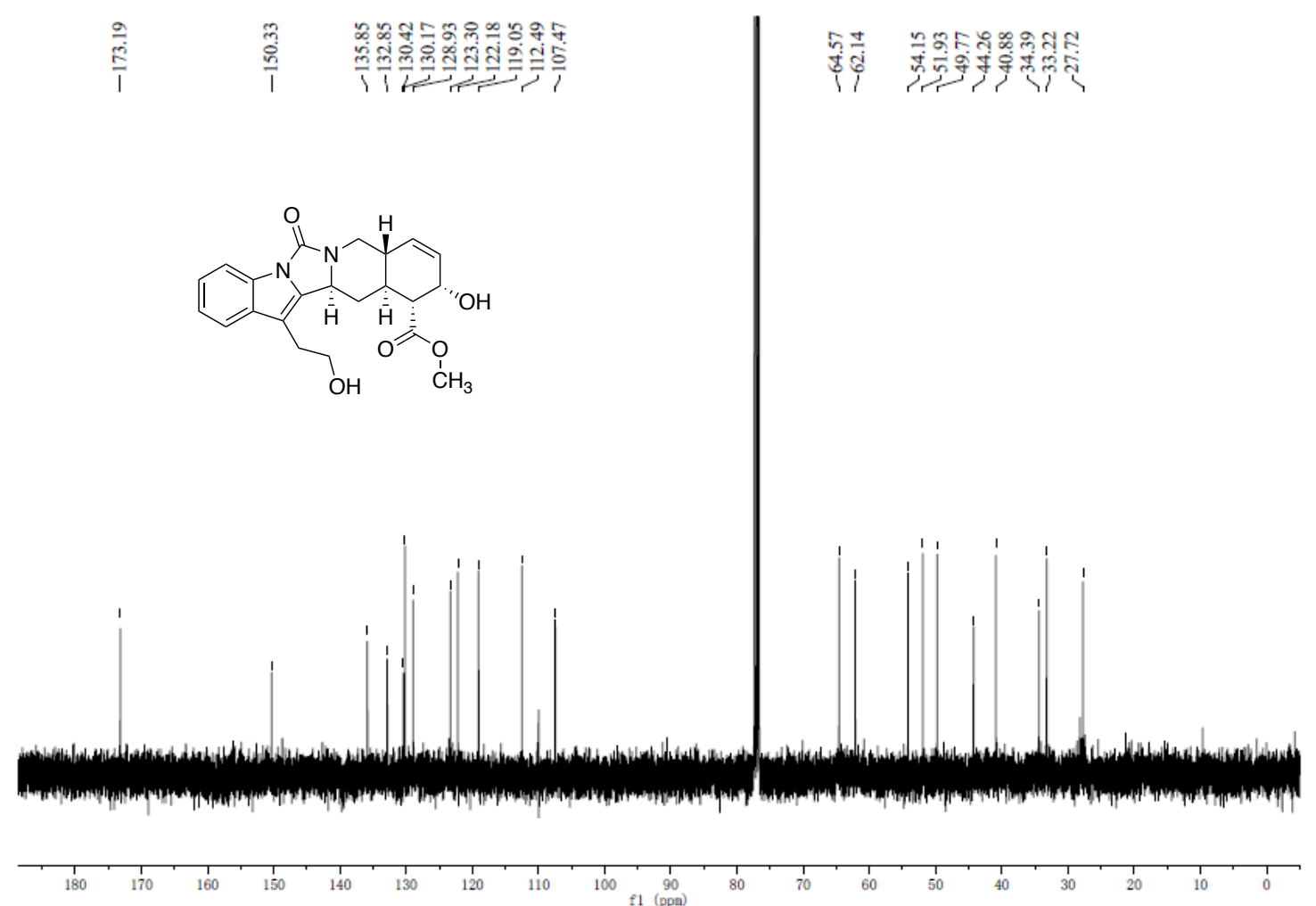

Figure S47. ${ }^{13} \mathrm{C}$ NMR Spectrum of $( \pm)-17\left(\mathrm{CDCl}_{3}, 101 \mathrm{MHz}\right)$ 


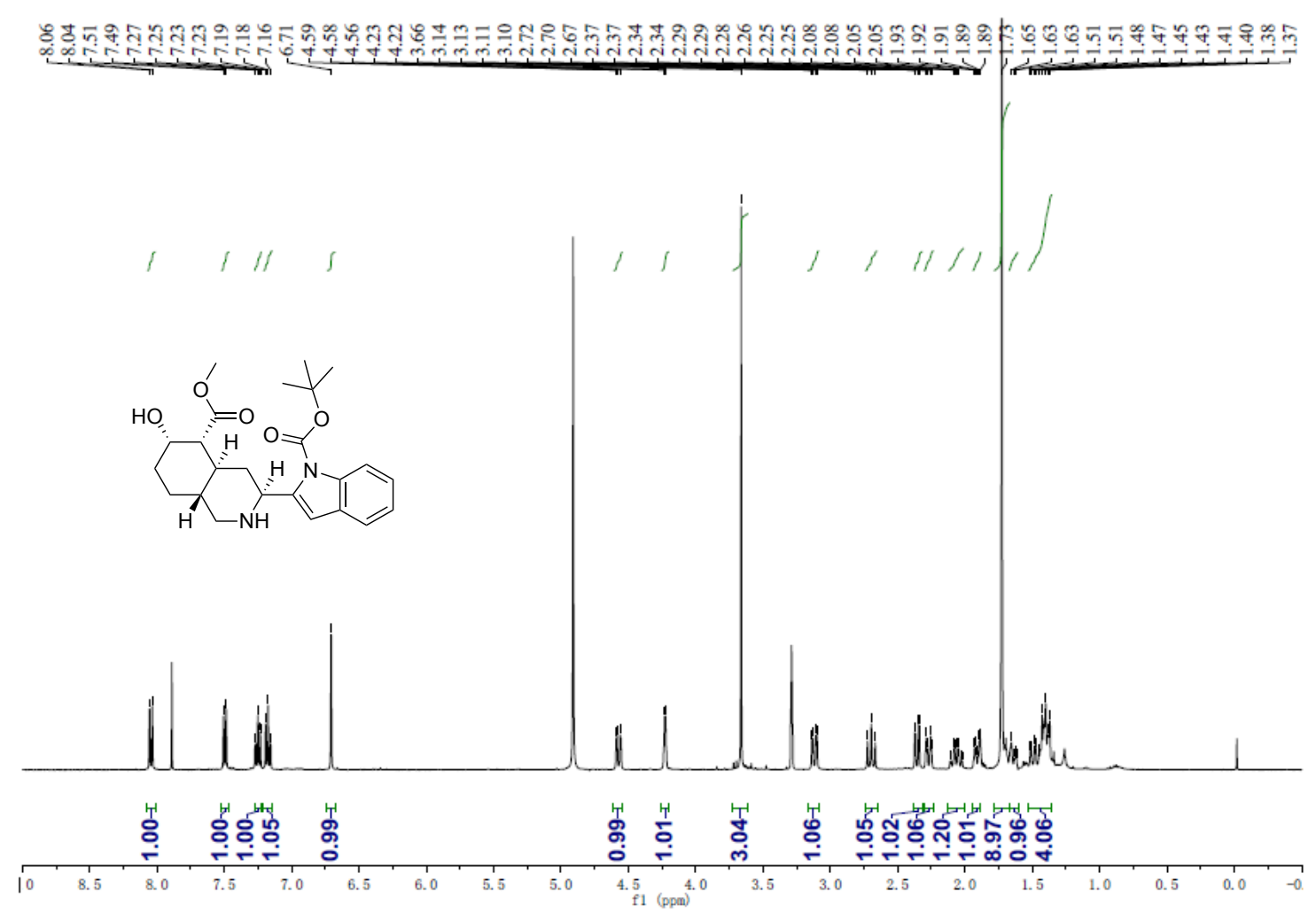

Figure S48. ${ }^{1} \mathrm{H}$ NMR Spectrum of $( \pm)-18 \mathrm{a}\left(\mathrm{CD}_{3} \mathrm{OD}, 400 \mathrm{MHz}\right)$
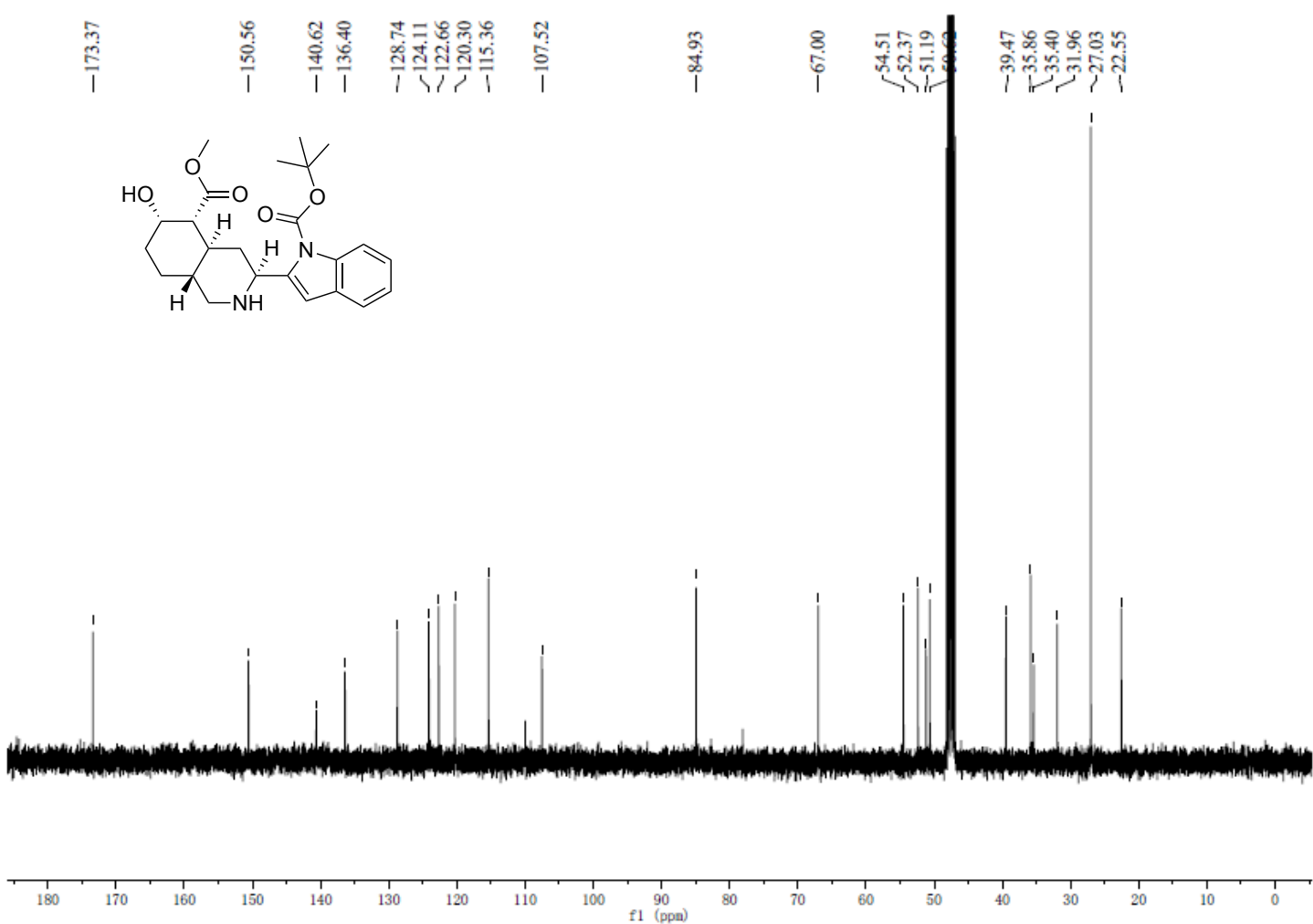

Figure S49. ${ }^{13} \mathrm{C}$ NMR Spectrum of $( \pm)-18 \mathrm{a}\left(\mathrm{CD}_{3} \mathrm{OD}, 101 \mathrm{MHz}\right)$ 


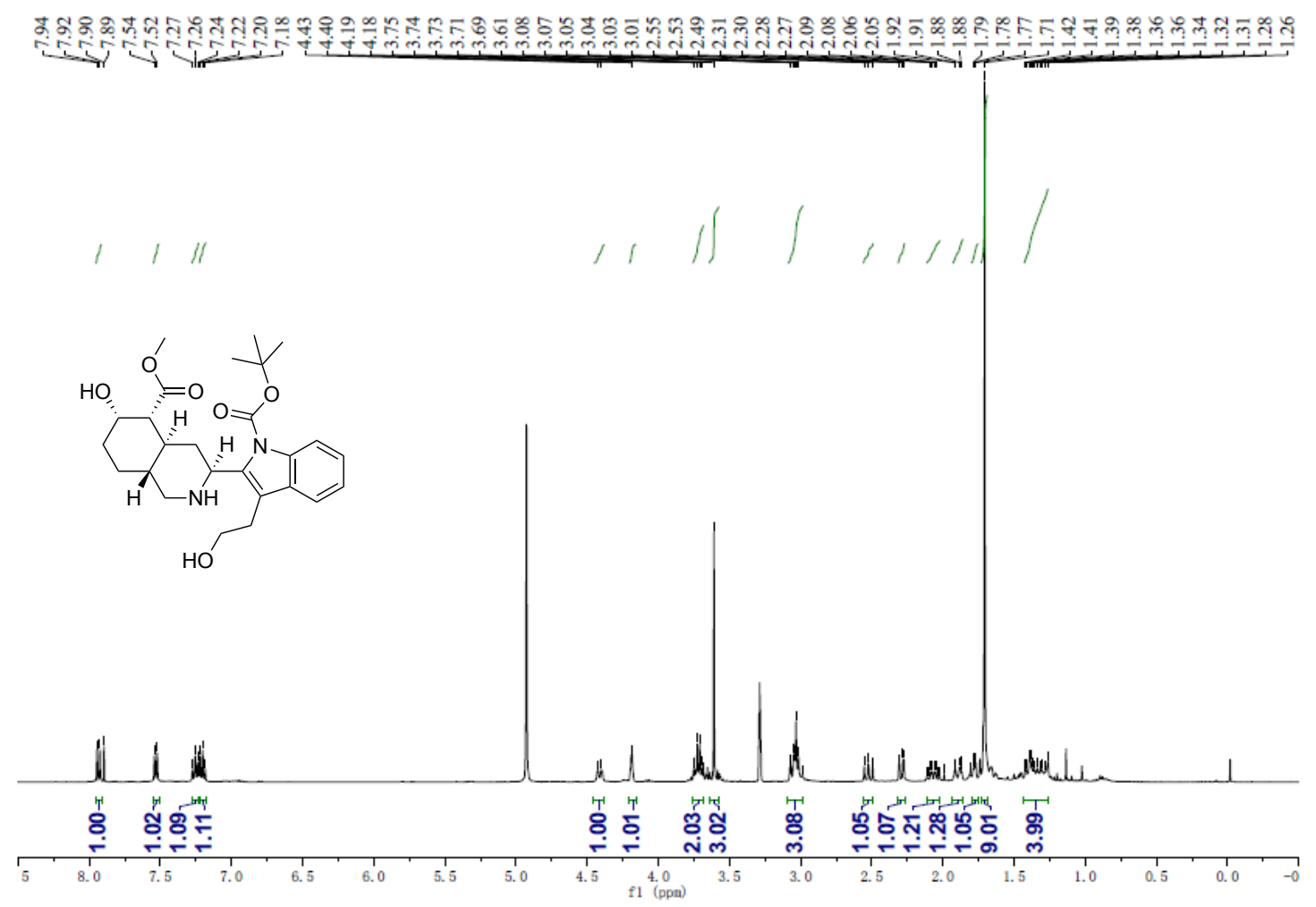

Figure S50. ${ }^{1} \mathrm{H}$ NMR Spectrum of $( \pm)-18 \mathrm{~b}\left(\mathrm{CD}_{3} \mathrm{OD}, 400 \mathrm{MHz}\right)$
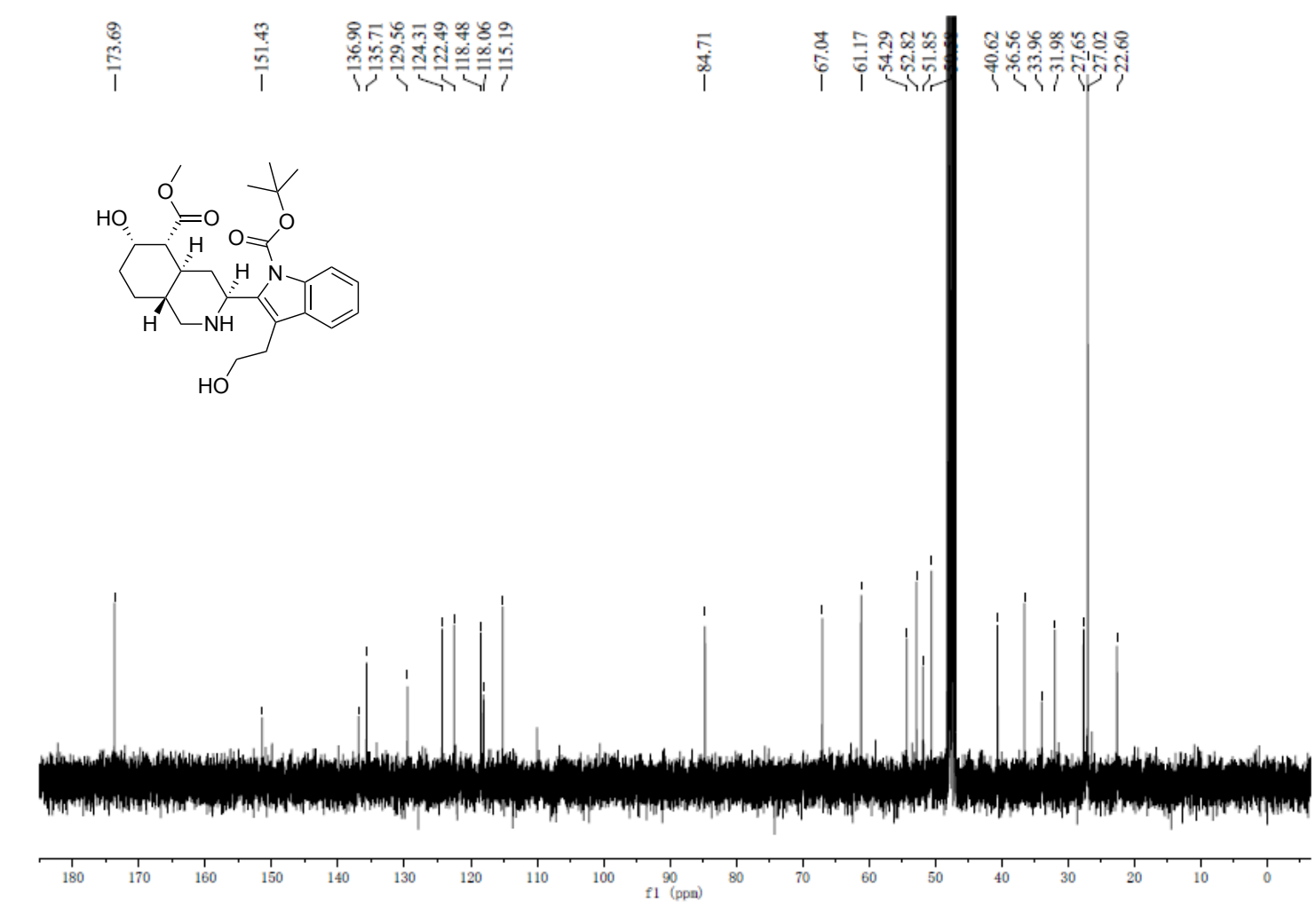

Figure S51. ${ }^{13} \mathrm{C}$ NMR Spectrum of $( \pm)-18 b\left(\mathrm{CD}_{3} \mathrm{OD}, 101 \mathrm{MHz}\right)$ 


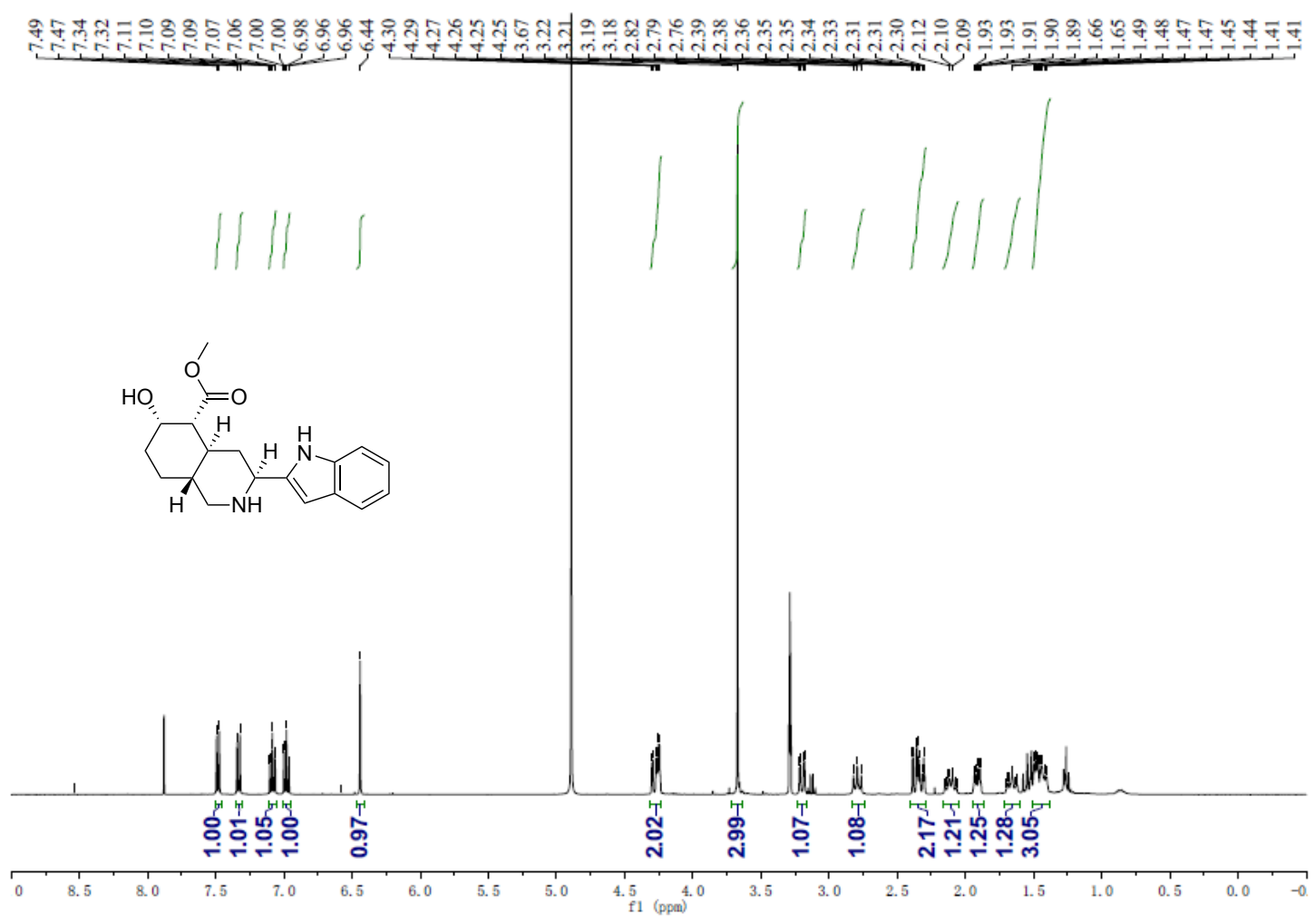

Figure S52. ${ }^{1} \mathrm{H}$ NMR Spectrum of $( \pm)-18 \mathrm{c}\left(\mathrm{CD}_{3} \mathrm{OD}, 400 \mathrm{MHz}\right)$
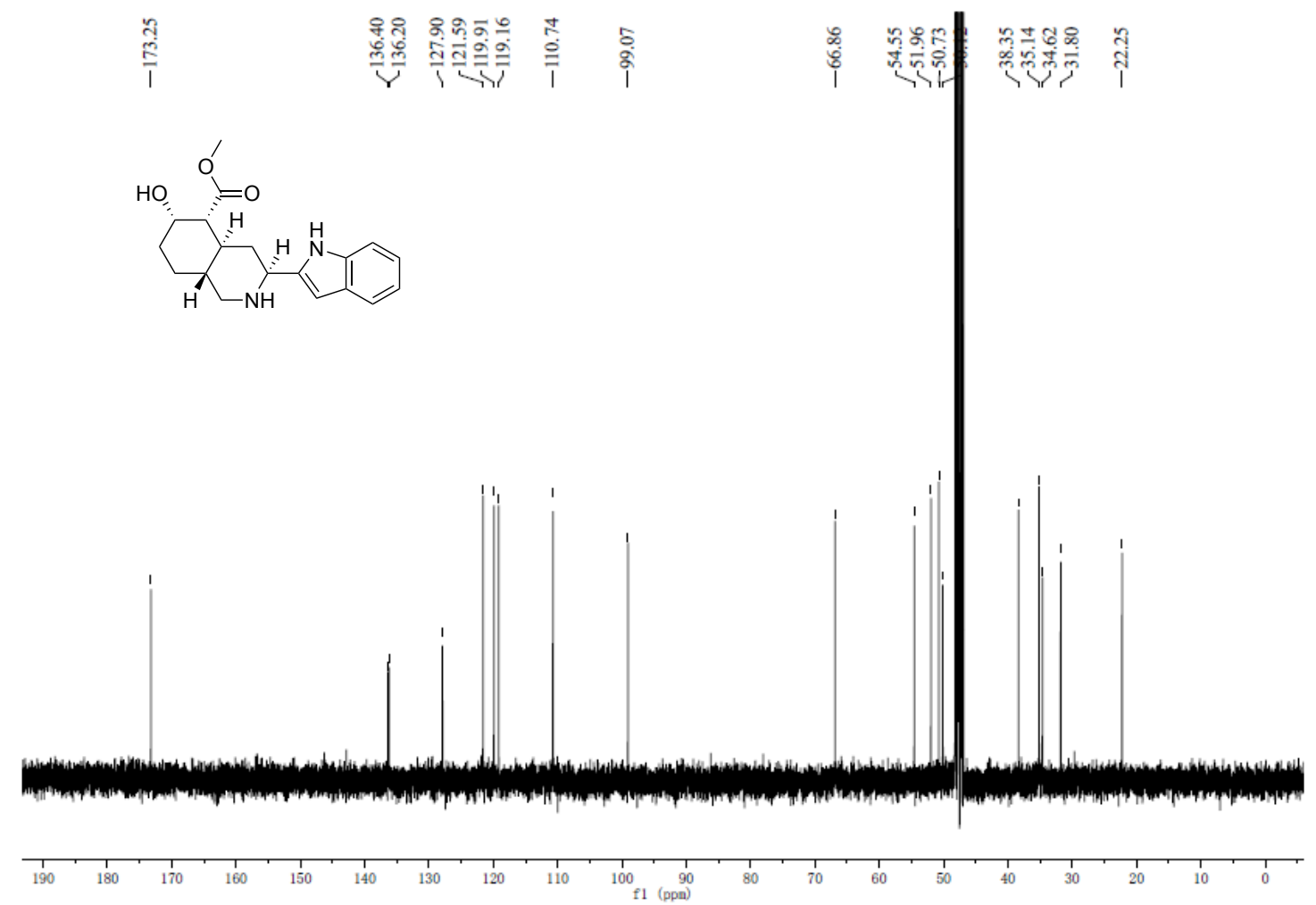

Figure S53. ${ }^{13} \mathrm{C}$ NMR Spectrum of $( \pm)-18 \mathrm{c}\left(\mathrm{CD}_{3} \mathrm{OD}, 101 \mathrm{MHz}\right)$ 


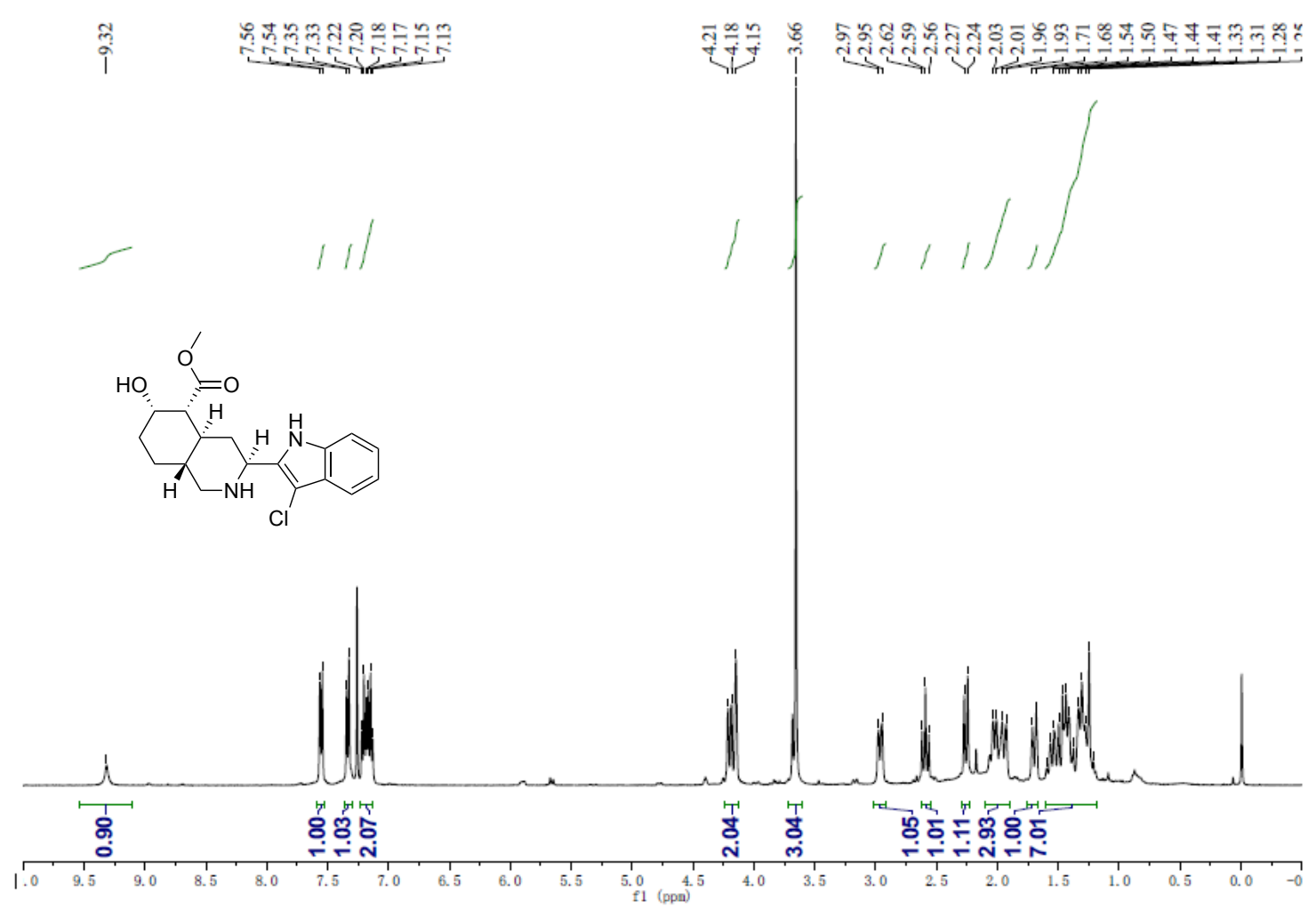

Figure S54. ${ }^{1} \mathrm{H}$ NMR Spectrum of $( \pm)-18 d\left(\mathrm{CDCl}_{3}, 400 \mathrm{MHz}\right)$

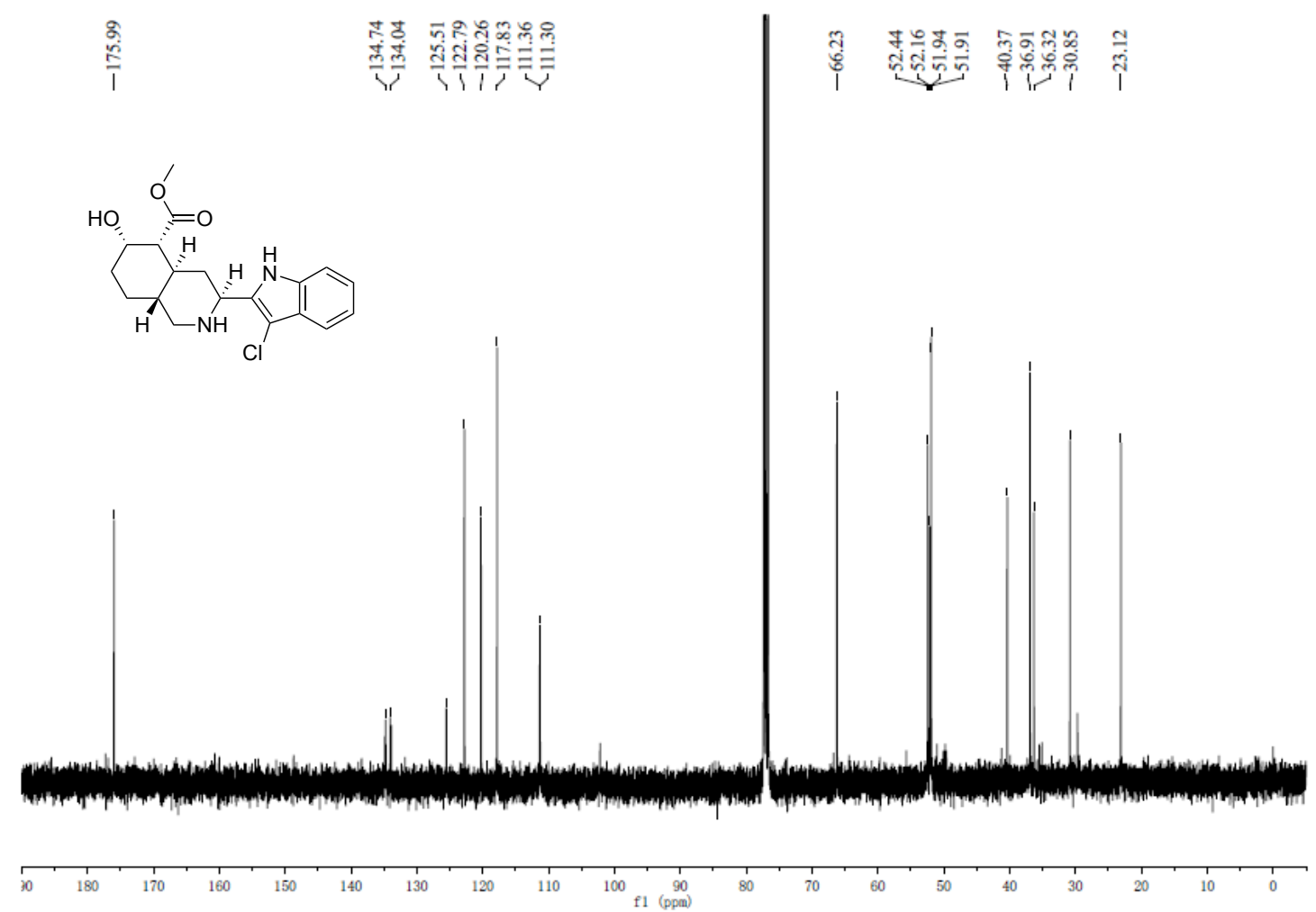

Figure S55. ${ }^{13} \mathrm{C}$ NMR Spectrum of $( \pm)-18 d\left(\mathrm{CDCl}_{3}, 101 \mathrm{MHz}\right)$ 


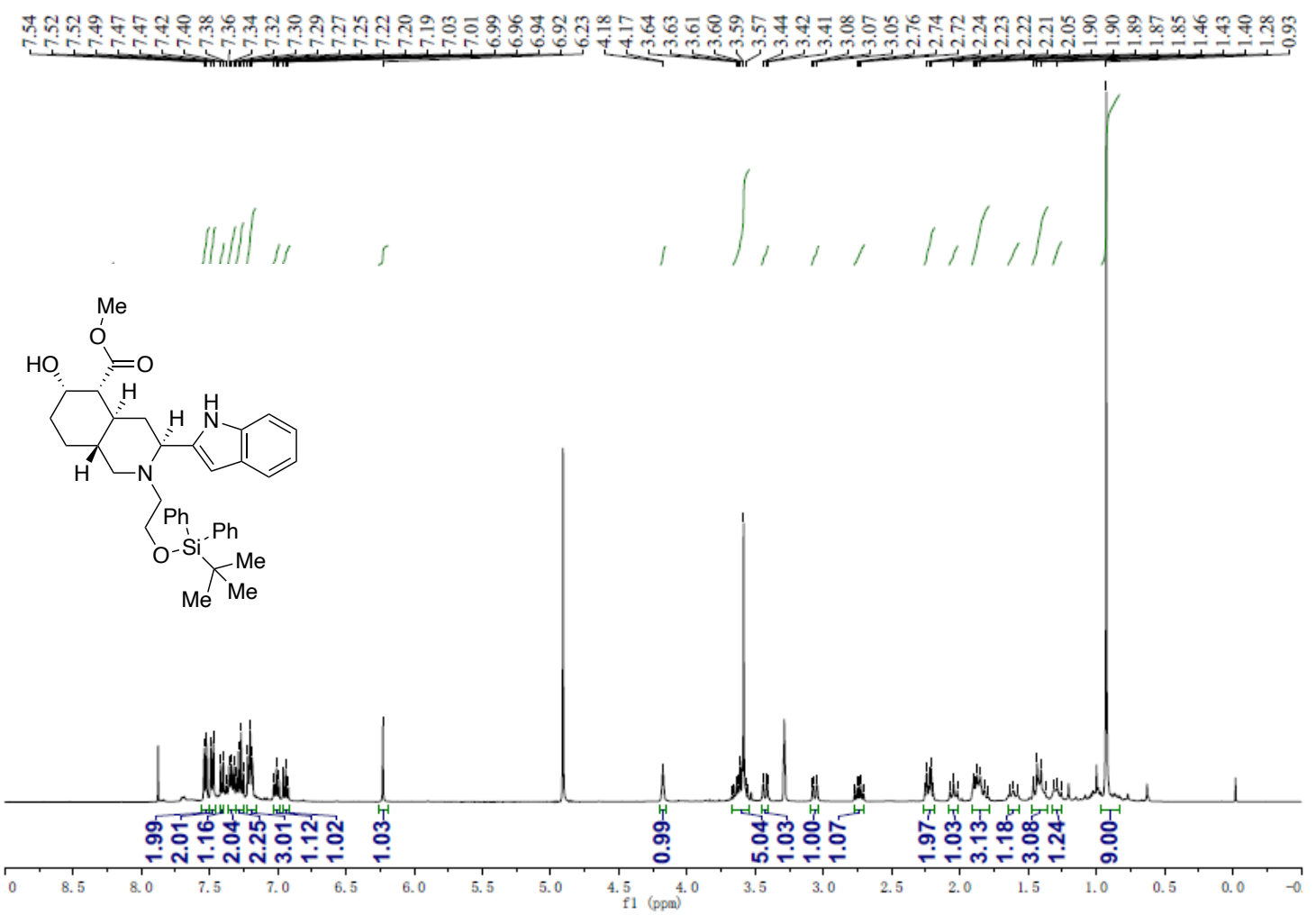

Figure S56. ${ }^{1} \mathrm{H}$ NMR Spectrum of Intermediate to $( \pm)-19\left(\mathrm{CD}_{3} \mathrm{OD}, 400 \mathrm{MHz}\right)$

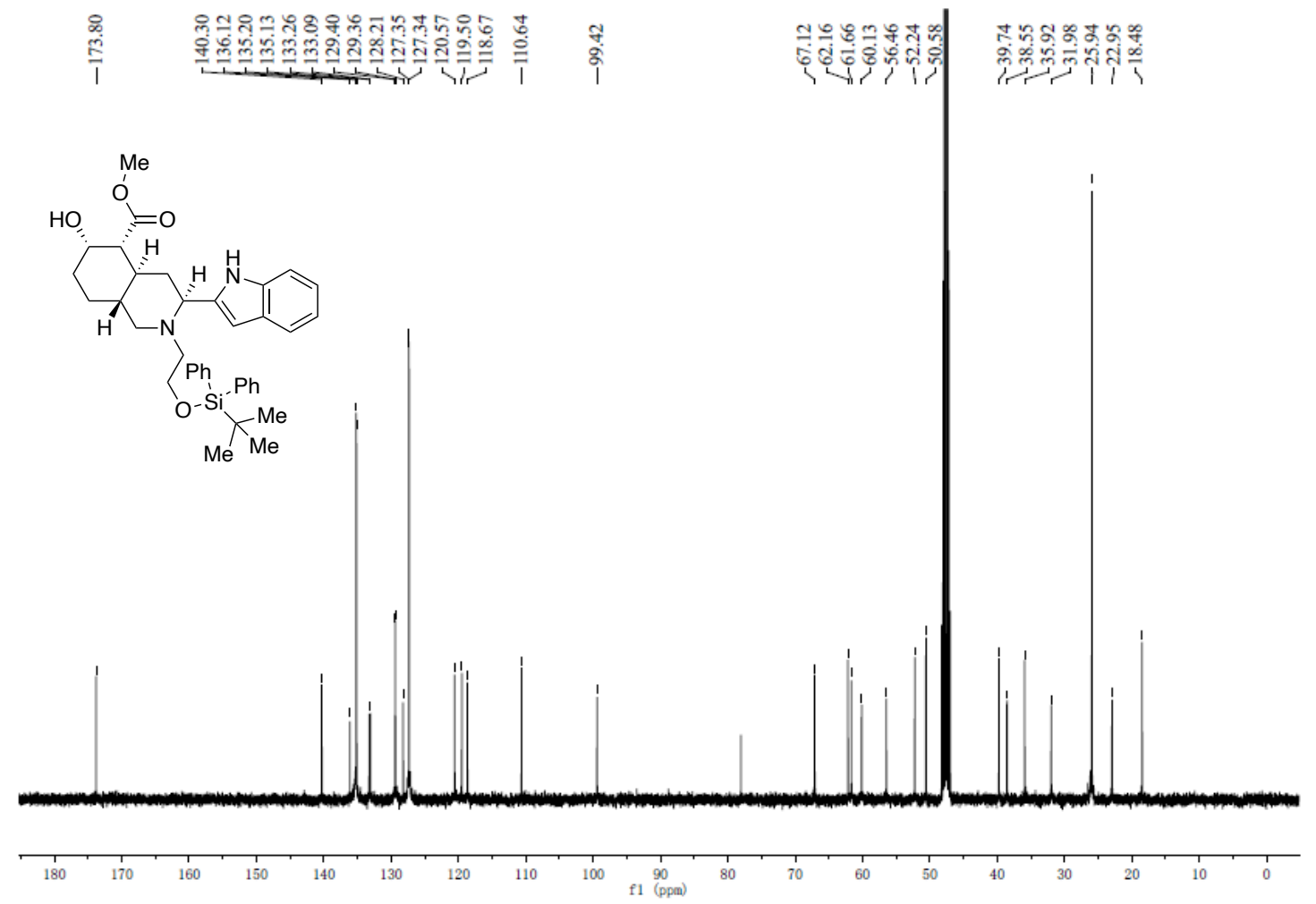

Figure S57. ${ }^{13} \mathrm{C}$ NMR Spectrum of Intermediate to $( \pm)-19\left(\mathrm{CD}_{3} \mathrm{OD}, 101 \mathrm{MHz}\right)$ 


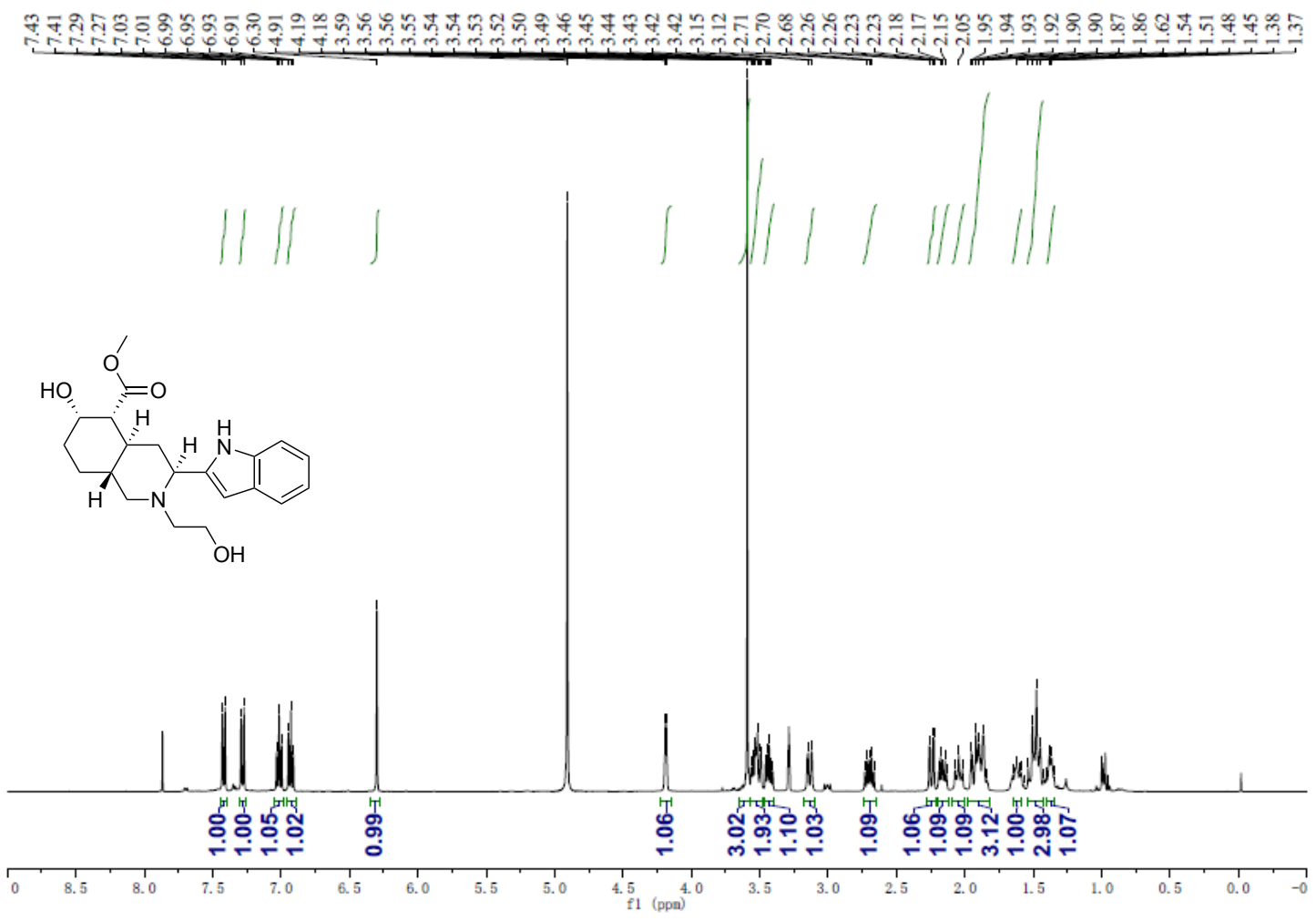

Figure S58. ${ }^{1} \mathrm{H}$ NMR Spectrum of $( \pm)-19\left(\mathrm{CD}_{3} \mathrm{OD}, 400 \mathrm{MHz}\right)$
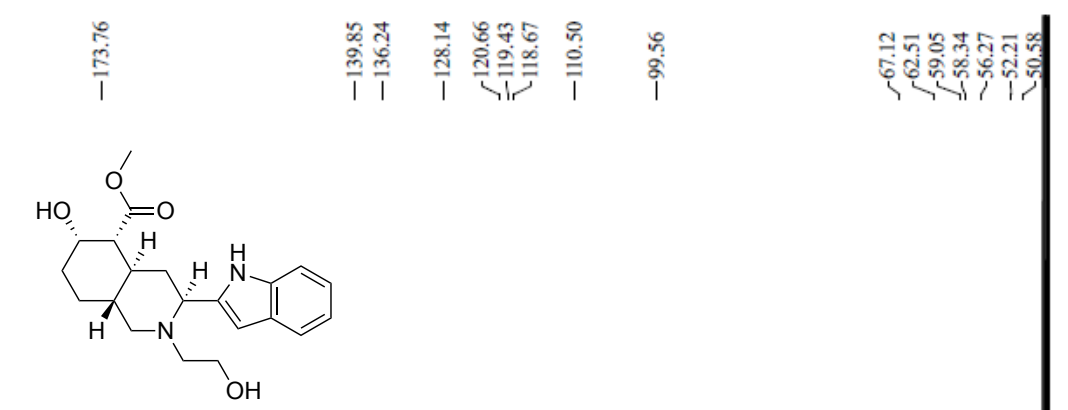

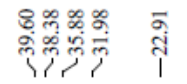
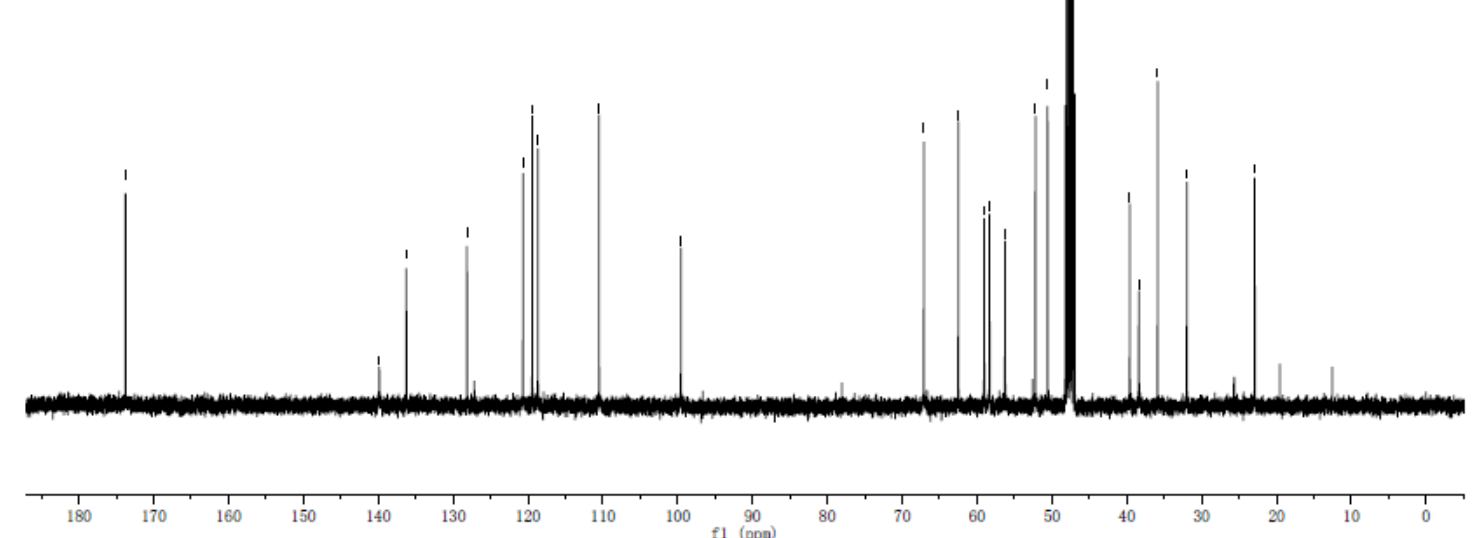

Figure S59. ${ }^{13} \mathrm{C}$ NMR Spectrum of $( \pm)-18 \mathrm{c}\left(\mathrm{CD}_{3} \mathrm{OD}, 101 \mathrm{MHz}\right)$ 
- 2D NMR and Structural Analysis of ( \pm -15a

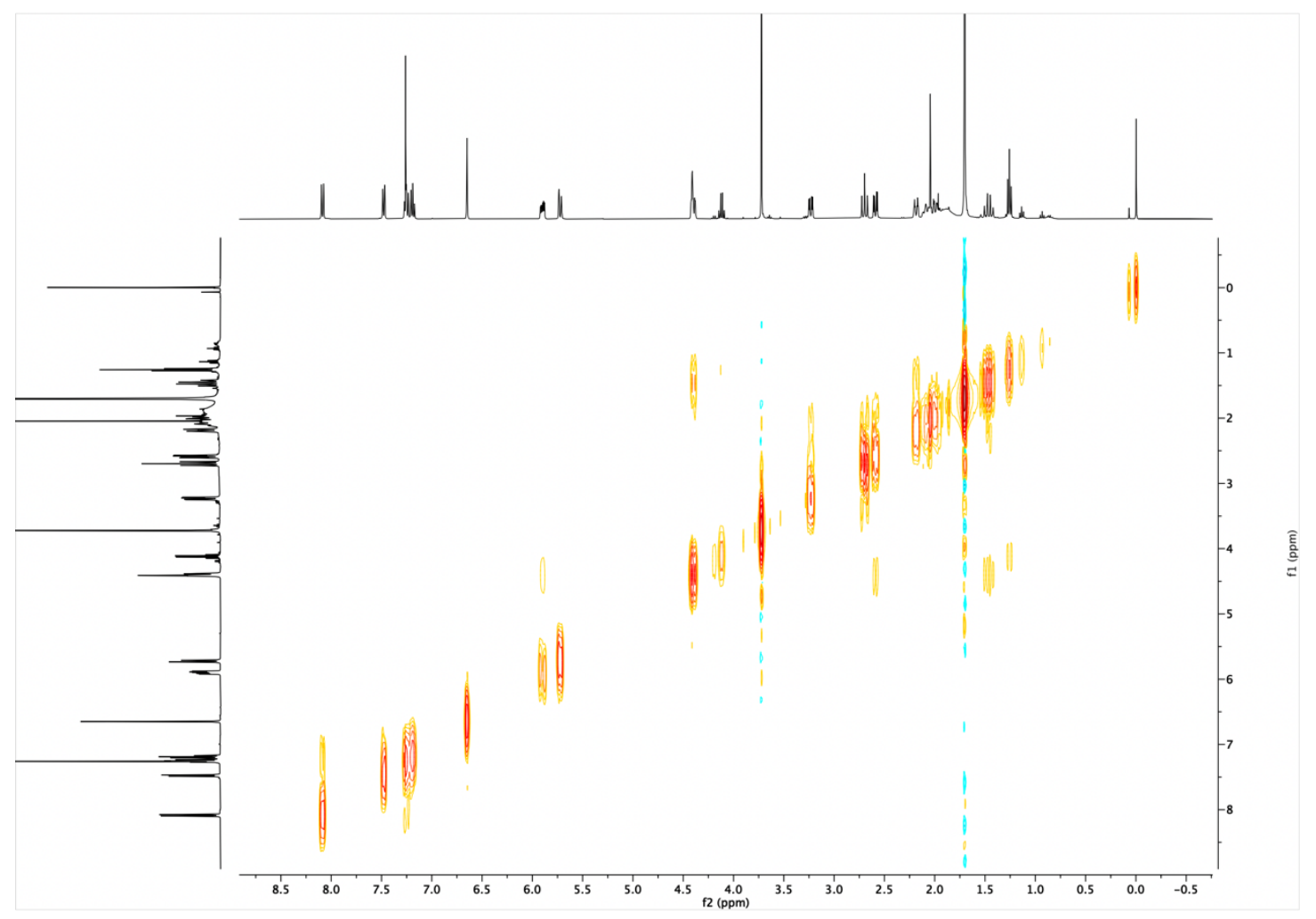

Figure S60. COSY Spectrum of ( $( \pm)-15 \mathrm{a}\left(400 \mathrm{MHz}, \mathrm{CDCl}_{3}\right)$

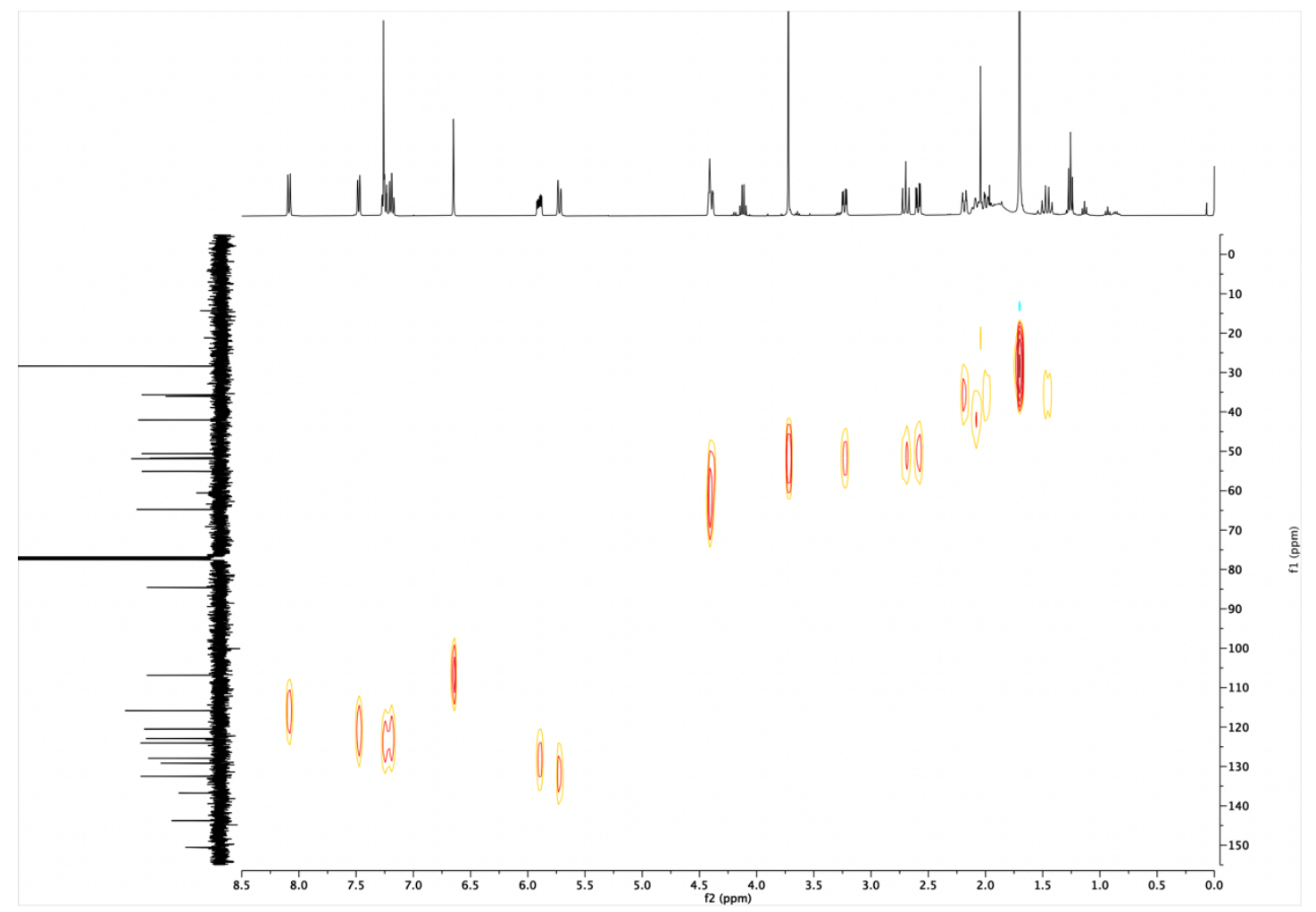

Figure S61. HSQC Spectrum of ( $( \pm)-15 \mathrm{a}\left(400 \mathrm{MHz}, \mathrm{CDCl}_{3}\right)$ 


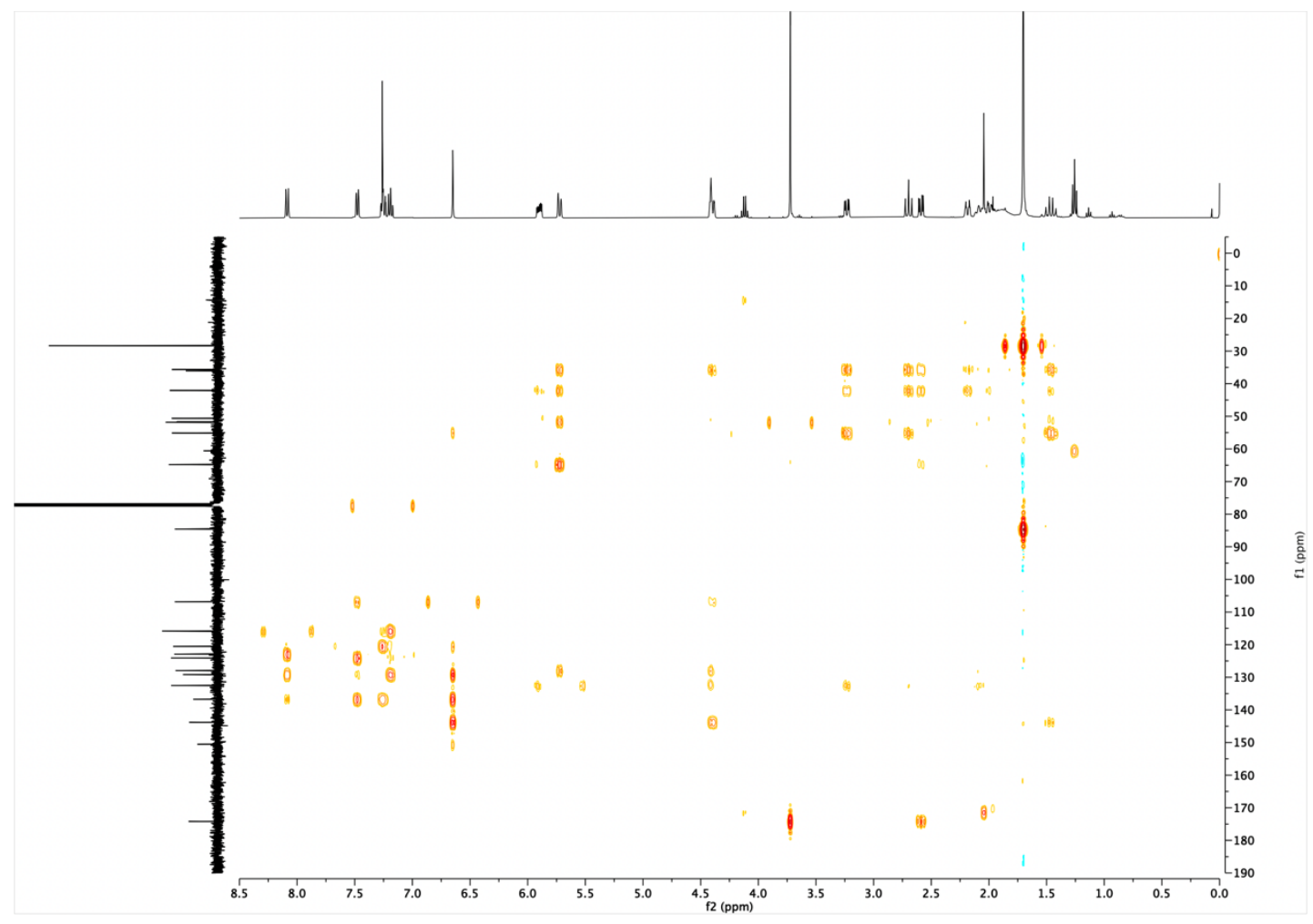

Figure S62. HMBC Spectrum of ( \pm )-15a (400 MHz, $\left.\mathrm{CDCl}_{3}\right)$

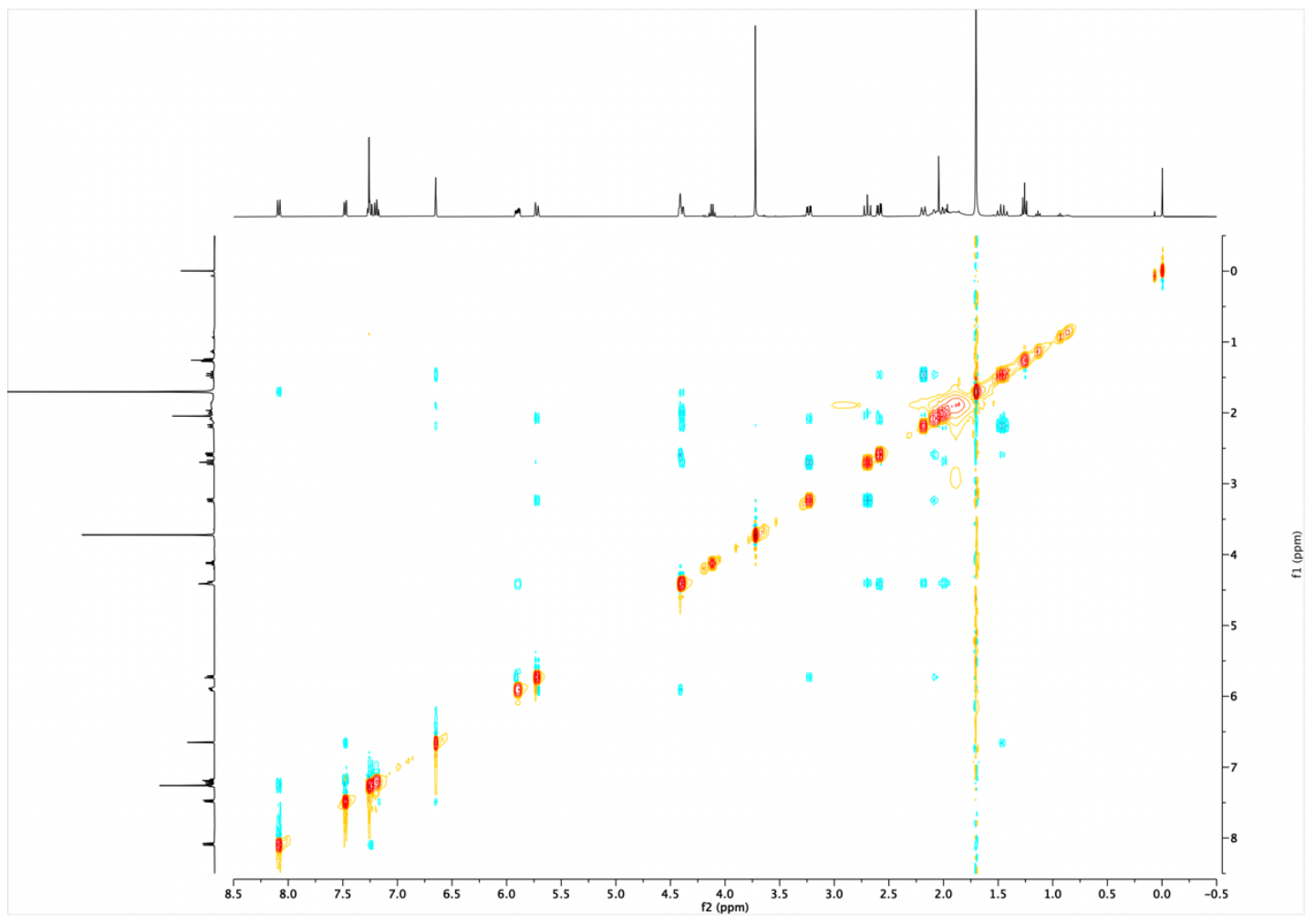

Figure S63. NOESY Spectrum of ( $( \pm)-15 a\left(400 \mathrm{MHz}, \mathrm{CDCl}_{3}\right)$

S40 
Table S2. 2D NMR Analysis of ( \pm )-15a (400 $\left.\mathrm{MHz}_{\mathrm{CDCl}}\right)$

\begin{tabular}{|c|c|c|c|c|c|}
\hline Signal & $\begin{array}{l}{ }^{\mathbf{1 3}} \mathbf{C} \\
(\delta, \mathrm{ppm})\end{array}$ & ${ }^{\mathbf{1}} \mathbf{H}(\delta, \mathrm{ppm})$ & COSY & HМBC (faint) & NOESY (faint) \\
\hline 1 & 174.17 & - & - & - & - \\
\hline 2 & 150.52 & - & - & - & - \\
\hline 3 & 142.78 & - & - & - & - \\
\hline 4 & 136.74 & - & - & - & - \\
\hline 5 & 132.52 & $5.72(\mathrm{br} \mathrm{d}, J=10.0 \mathrm{~Hz}, 1 \mathrm{H})$ & 7 & 7, 14, (16 or 17), 19, 21 & 7, 17A, $(17 B), 19$ \\
\hline 6 & 129.18 & - & - & - & - \\
\hline 7 & 127.93 & $5.90(\mathrm{ddd}, J=9.8,4.7,2.7 \mathrm{~Hz}, 1 \mathrm{H})$ & $5,14 / 15$ & $5,14,18,19$ & 5,14 \\
\hline 8 & 124.08 & $7.29-7.22(\mathrm{~m}$, overlap $w /$ solvent, $1 \mathrm{H})$ & 9,11 & $4,10,11$ & 11 \\
\hline 9 & 122.90 & $7.19(\mathrm{td}, J=7.5,1.0 \mathrm{~Hz}, 1 \mathrm{H})$ & 8,10 & $6,(8,10), 11$ & 10 \\
\hline 10 & 120.52 & $7.50-7.46(\mathrm{~m}, 1 \mathrm{H})$ & 9 & $4,(6), 8,(11), 12$ & 9, 12 \\
\hline 11 & 115.83 & $8.09(\mathrm{~d}, J=8.4 \mathrm{~Hz}, 1 \mathrm{H})$ & 8 & $4,6,9$ & 8,22 \\
\hline 12 & 106.85 & $6.65(\mathrm{~s}, 1 \mathrm{H})$ & & $2,3,4,6,10,15$ & $\begin{array}{l}10,(15),(20), 21 \mathrm{~A}, \\
21 \mathrm{~B}\end{array}$ \\
\hline 13 & 84.58 & - & - & - & - \\
\hline 14 & 64.79 & $4.41(\mathrm{~s} ?$, overlap $w / 15,1 \mathrm{H})$ & & $5,7,18$ & 7,18 \\
\hline 15 & 55.12 & $4.40(\mathrm{~m}$, overlap $w / 14,1 \mathrm{H})$ & 21B & $3,12,20 / 21$ & $17 \mathrm{~B}, 20,21 \mathrm{~A},(22)$ \\
\hline 16 & 51.85 & $3.72(\mathrm{~s}, 3 \mathrm{H})$ & - & 1 & - \\
\hline 17A & 5171 & $3.23(\mathrm{dd}, J=11.3,3.6 \mathrm{~Hz}, 1 \mathrm{H})$ & & $5,15,19,20$ & $5,17 B, 19$ \\
\hline 17B & $51 . / 1$ & $2.70(\operatorname{app~t}, J=11.3 \mathrm{~Hz}, 1 \mathrm{H})$ & & 15, (19), 20 & $15,17 \mathbf{A},(20)$ \\
\hline 18 & 50.59 & $2.59(\mathrm{dd}, J=11.6,3.9 \mathrm{~Hz}, 1 \mathrm{H})$ & & $1,14,19,20 / 21$ & $14,19,21 \mathrm{~B}$ \\
\hline 19 & 42.09 & $2.08(\mathrm{~m}$, overlap $w / \mathbf{2 0}, 1 \mathrm{H})$ & & $5,17,20 / 21$ & $(5), 17 \mathrm{~A}, 18,21 \mathrm{~B}$ \\
\hline 20 & 36.06 & $2.00(\mathrm{~m}$, overlap $w / \mathbf{1 9}, 1 \mathrm{H})$ & & $18,19,21$ & $15,(17 B)$ \\
\hline 21A & 3566 & $2.22-2.15(\mathrm{~m}, 1 \mathrm{H})$ & & $15,19,20$ & $15,21 B$ \\
\hline 21B & 35.66 & $1.46(\operatorname{app~q}, J=11.5 \mathrm{~Hz}, 1 \mathrm{H})$ & 15 & $3,15,19,20$ & $12,18,19,21 \mathbf{A}$ \\
\hline 22 & 28.38 & $1.70(\mathrm{~s}, 9 \mathrm{H})$ & - & 13 & not determined \\
\hline
\end{tabular}

Figure S64. Structural Analysis of ( \pm )-15a from NOESY Crosspeaks (400 $\left.\mathrm{MHz}, \mathrm{CDCl}_{3}\right)$

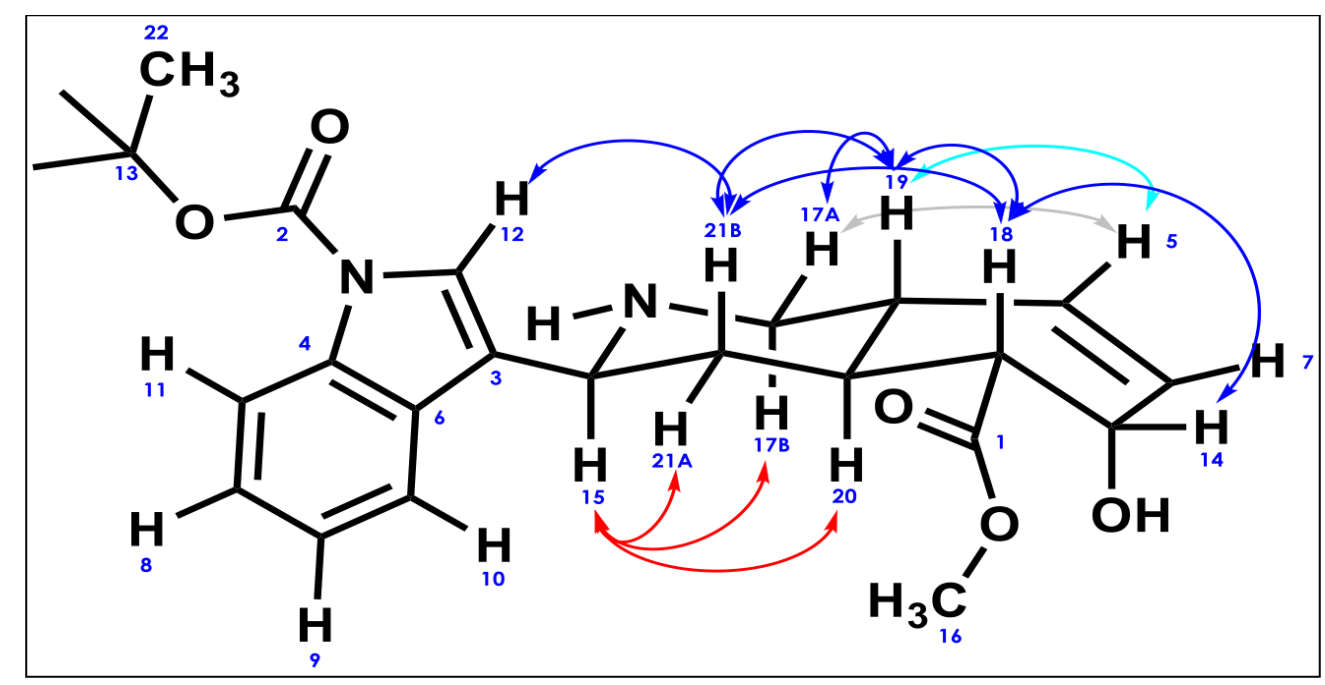




\section{- Complete Bioassay Data Tables}

Table S3. Raw Bioassay Data Against Normal Human Mucosal Cell Line GES-1

\begin{tabular}{|c|c|c|c|c|c|c|c|c|c|c|}
\hline \multirow{2}{*}{$\begin{array}{l}\# / \\
\text { Conc } \\
(\mu \mathrm{g} / \mathrm{mL})\end{array}$} & \multicolumn{3}{|c|}{ Experiment 1} & \multicolumn{3}{|c|}{ Experiment 2} & \multicolumn{3}{|c|}{ Experiment 3} & \multirow{2}{*}{$\mathrm{IC}_{50}(\mu \mathrm{g} / \mathrm{mL})$} \\
\hline & $\begin{array}{l}\text { starting } \\
\text { value }\end{array}$ & $\begin{array}{l}\text { minus } \\
\text { blank }\end{array}$ & $\begin{array}{l}\text { inhibition } \\
\text { ratio }\end{array}$ & $\begin{array}{l}\text { starting } \\
\text { value }\end{array}$ & $\begin{array}{l}\text { minus } \\
\text { blank }\end{array}$ & $\begin{array}{l}\text { inhibition } \\
\text { ratio }\end{array}$ & $\begin{array}{l}\text { starting } \\
\text { value }\end{array}$ & $\begin{array}{l}\text { minus } \\
\text { blank }\end{array}$ & $\begin{array}{l}\text { inhibition } \\
\text { ratio }\end{array}$ & \\
\hline \multicolumn{11}{|l|}{$( \pm)-15 \mathbf{a}$} \\
\hline 0 & 0.863 & 0.813 & - & 0.847 & 0.797 & - & 0.948 & 0.898 & - & Exp. 1: \\
\hline 50 & 0.532 & 0.436 & 46.371 & 0.422 & 0.326 & 59.09661 & 0.441 & 0.345 & 61.581 & Exp. 2: \\
\hline 100 & 0.407 & 0.311 & 61.747 & 0.349 & 0.253 & 68.25596 & 0.364 & 0.268 & 70.156 & Exp. 3: \\
\hline 150 & 0.397 & 0.301 & 62.977 & 0.290 & 0.194 & 75.65872 & 0.256 & 0.16 & 82.183 & 39.718 \\
\hline 200 & 0.291 & 0.195 & 76.015 & 0.224 & 0.128 & 83.93977 & 0.240 & 0.144 & 83.964 & \multirow{2}{*}{$93 \mu \mathrm{M}$} \\
\hline 250 & 0.305 & 0.209 & 74.293 & 0.264 & 0.168 & 78.92095 & 0.247 & 0.151 & 83.185 & \\
\hline \multicolumn{11}{|l|}{$( \pm)-\mathbf{1 6 a}$} \\
\hline 0 & 0.863 & 0.813 & - & 0.847 & 0.797 & - & 0.948 & 0.898 & - & \multirow{3}{*}{$\begin{array}{ll}\text { Exp. 1: } & 76.451 \\
\text { Exp. 2: } & 71.738 \\
\text { Exp. 3: } & 69.708 \\
\end{array}$} \\
\hline 50 & 316 & 0.72 & 11.439 & 0.765 & 0.669 & 16.06023 & 0.822 & 0.726 & 19.154 & \\
\hline 100 & 219 & 0.123 & 84.871 & 0.190 & 0.094 & 88.20577 & 0.211 & 0.115 & 87.194 & \\
\hline 150 & 0.163 & 0.067 & 91.759 & 0.157 & 0.061 & 92.3463 & 0.169 & 0.073 & 91.871 & Avg: 72.632 \\
\hline 200 & 149 & 0.053 & 93.481 & 0.152 & 0.056 & 92.97365 & 0.127 & 0.031 & 96.548 & \multirow{2}{*}{$223 \mu \mathrm{M}$} \\
\hline 250 & 0.138 & 0.042 & 94.834 & 0.121 & 0.025 & 96.86324 & 0.114 & 0.018 & 97.996 & \\
\hline \multicolumn{11}{|l|}{$( \pm)-16 b$} \\
\hline 0 & 0.978 & 0.928 & - & 1.017 & 0.967 & - & 0.856 & 0.806 & - & \multirow{3}{*}{$\begin{array}{ll}\text { Exp. 1: } & 97.077 \\
\text { Exp. 2: } & 85.236 \\
\text { Exp. 3: } & 91.988 \\
\end{array}$} \\
\hline 50 & 843 & 0.747 & 19.504 & & 0.722 & 25.33609 & & 0.64 & 20.596 & \\
\hline 100 & 0.526 & 0.43 & 53.664 & 0.509 & 0.413 & 57.29059 & 0.474 & 0.378 & 53.102 & \\
\hline 150 & 0.375 & 0.279 & 69.935 & 0.328 & 0.232 & 76.00827 & 0.288 & 0.192 & 76.179 & Avg: 91.434 \\
\hline 200 & 294 & 0.198 & 78.664 & 0.240 & 0.144 & 85.10858 & 0.218 & 0.122 & 84.864 & \multirow{2}{*}{$253 \mu \mathrm{M}$} \\
\hline 250 & 0.176 & 0.08 & 91.379 & 0.164 & 0.068 & 92.96794 & 0.162 & 0.066 & 91.811 & \\
\hline \multicolumn{11}{|l|}{$( \pm)-17$} \\
\hline 0 & 978 & 0.928 & - & 1.017 & 0.967 & - & 0.856 & 0.806 & & \multirow{4}{*}{$\begin{array}{rr}\text { Exp. 1: } & 168.009 \\
\text { Exp. 2: } & 127.387 \\
\text { Exp. 3: } & 171.240 \\
\text { Avg: } & \mathbf{1 5 5 . 5 4 5} \\
\end{array}$} \\
\hline 50 & 773 & 677 & 27.047 & & 0.622 & 35.67735 & 0.701 & 0.605 & 24.938 & \\
\hline 100 & 657 & 0.561 & 39.547 & 0.583 & 0.487 & 49.63806 & 0.692 & 0.596 & 26.055 & \\
\hline 150 & 0.645 & 0.549 & 40.841 & 0.588 & 0.492 & 49.12099 & 0.528 & 0.432 & 46.402 & \\
\hline 200 & 0.592 & 0.496 & 46.552 & 0.591 & 0.495 & 48.81075 & 0.523 & 0.427 & 47.022 & \multirow{2}{*}{$392 \mu \mathrm{M}$} \\
\hline 250 & 0.380 & 0.284 & 69.397 & 0.398 & 0.302 & 68.76939 & 0.330 & 0.234 & 70.968 & \\
\hline
\end{tabular}

Table S4. Raw Bioassay Data Against Gastric Cancer Cell Line SGC-7901

\begin{tabular}{|c|c|c|c|c|c|c|c|c|c|c|}
\hline \multirow{2}{*}{$\begin{array}{l}\# I \\
\text { Conc } \\
(\mu \mathrm{g} / \mathrm{mL})\end{array}$} & \multicolumn{3}{|c|}{ Experiment 1} & \multicolumn{3}{|c|}{ Experiment 2} & \multicolumn{3}{|c|}{ Experiment 3} & \multirow{2}{*}{$\mathrm{IC}_{50}(\mu \mathrm{g} / \mathrm{mL})$} \\
\hline & $\begin{array}{l}\text { starting } \\
\text { value }\end{array}$ & $\begin{array}{l}\text { minus } \\
\text { blank }\end{array}$ & $\begin{array}{l}\text { inhibition } \\
\text { ratio }\end{array}$ & $\begin{array}{l}\text { starting } \\
\text { value }\end{array}$ & $\begin{array}{l}\text { minus } \\
\text { blank }\end{array}$ & $\begin{array}{l}\text { inhibition } \\
\text { ratio }\end{array}$ & $\begin{array}{l}\text { starting } \\
\text { value }\end{array}$ & $\begin{array}{l}\text { minus } \\
\text { blank }\end{array}$ & $\begin{array}{l}\text { inhibition } \\
\text { ratio }\end{array}$ & \\
\hline \multicolumn{11}{|l|}{$( \pm)-15 a$} \\
\hline 0 & 1.167 & 1.117 & - & 1.084 & 1.034 & - & 1.050 & 1.000 & - & Exp. 1: \\
\hline 50 & 0.520 & 0.42 & 62.399 & 0.630 & 0.53 & 48.743 & 0.498 & 0.398 & 60.2 & Exp. 2: \\
\hline 100 & 0.439 & 0.339 & 69.651 & 0.467 & 0.367 & 64.507 & 0.474 & 0.374 & 62.6 & Exp. 3: 35.037 \\
\hline 150 & 0.399 & 0.299 & 73.232 & 0.446 & 0.346 & 66.538 & 0.424 & 0.324 & 67.6 & 44.415 \\
\hline 200 & 0.201 & 0.101 & 90.958 & 0.292 & 0.192 & 81.431 & 0.319 & 0.219 & 78.1 & \multirow{2}{*}{$104 \mu \mathrm{M}$} \\
\hline 250 & 0.148 & 0.048 & 95.703 & 0.189 & 0.089 & 91.393 & 0.262 & 0.162 & 83.8 & \\
\hline \multicolumn{11}{|l|}{$( \pm)-16 a$} \\
\hline 0 & 1.167 & 1.117 & - & 1.084 & 1.034 & - & 1.050 & 1 & - & Exp. 1: \\
\hline 50 & 0.963 & 0.863 & 22.739 & 0.917 & 0.817 & 20.986 & 0.965 & 0.865 & 13.5 & Exp. 2: \\
\hline 100 & 0.278 & 0.178 & 84.064 & 0.300 & 0.2 & 80.658 & 0.470 & 0.37 & 63 & Exp. 3: \\
\hline 150 & 0.240 & 0.14 & 87.466 & 0.246 & 0.146 & 85.88 & 0.258 & 0.158 & 84.2 & 72.632 \\
\hline 200 & 0.140 & 0.04 & 96.419 & 0.142 & 0.042 & 95.938 & 0.123 & 0.023 & 97.7 & \multirow{2}{*}{$233 \mu \mathrm{M}$} \\
\hline 250 & 0.109 & 0.009 & 99.194 & 0.104 & 0.004 & 99.613 & 0.108 & 0.008 & 99.2 & \\
\hline \multicolumn{11}{|l|}{$( \pm)-16 \mathrm{~b}$} \\
\hline 0 & 1.073 & 1.023 & - & 1.085 & 1.035 & - & 1.069 & 1.019 & - & 104.065 \\
\hline 50 & 0.981 & 0.881 & 13.881 & 0.870 & 0.77 & 25.604 & 0.994 & 0.894 & 12.267 & Exp. 2: \\
\hline 100 & 0.591 & 0.491 & 52.004 & 0.639 & 0.539 & 47.923 & 0.618 & 0.518 & 49.166 & Exp. 3: \\
\hline 150 & 0.370 & 0.27 & 73.607 & 0.422 & 0.322 & 68.889 & 0.400 & 0.3 & 70.559 & 104.803 \\
\hline
\end{tabular}




\begin{tabular}{|c|c|c|c|c|c|c|c|c|c|c|}
\hline $\begin{array}{l}200 \\
250\end{array}$ & $\begin{array}{l}0.351 \\
0.245 \\
\end{array}$ & $\begin{array}{l}0.251 \\
0.145 \\
\end{array}$ & $\begin{array}{l}75.464 \\
85.826\end{array}$ & $\begin{array}{l}0.366 \\
0.316 \\
\end{array}$ & \begin{tabular}{|l|}
0.266 \\
0.216 \\
\end{tabular} & $\begin{array}{r}74.3 \\
79.13 \\
\end{array}$ & \begin{tabular}{|l|}
0.334 \\
0.313 \\
\end{tabular} & \begin{tabular}{|l|}
0.234 \\
0.213 \\
\end{tabular} & $\begin{array}{l}77.036 \\
79.097\end{array}$ & $290 \mu \mathrm{M}$ \\
\hline \multicolumn{11}{|l|}{$( \pm)-17$} \\
\hline 0 & 1.073 & 1.023 & - & 1.085 & 1.035 & - & 1.069 & 1.019 & - & Exp. 1: \\
\hline 50 & 0.657 & 0.557 & 45.552 & 0.533 & 0.433 & 58.164 & 0.450 & 0.35 & 65.653 & Exp. 2: \\
\hline 100 & 0.458 & 0.358 & 65.005 & 0.376 & 0.276 & 73.333 & 0.372 & 0.272 & 73.307 & Exp. 3: \\
\hline 150 & 0.328 & 0.228 & 77.713 & 0.288 & 0.188 & 81.836 & 0.278 & 0.178 & 82.532 & 47.402 \\
\hline 200 & 0.200 & 0.1 & 90.225 & 0.174 & 0.074 & 92.85 & 0.151 & 0.051 & 94.995 & \multirow{2}{*}{$120 \mu \mathrm{M}$} \\
\hline 250 & 0.123 & 0.023 & 97.752 & 0.113 & 0.013 & 98.744 & 0.152 & 0.052 & 94.897 & \\
\hline
\end{tabular}

Table S5. Raw Bioassay Data Against Pancreatic Cancer Cell Line PATU-8988

\begin{tabular}{|c|c|c|c|c|c|c|c|c|c|c|}
\hline \multirow{2}{*}{$\begin{array}{l}\# / \\
\text { Conc } \\
(\mu \mathrm{g} / \mathrm{mL})\end{array}$} & \multicolumn{3}{|c|}{ Experiment 1 } & \multicolumn{3}{|c|}{ Experiment 2} & \multicolumn{3}{|c|}{ Experiment 3 } & \multirow[t]{2}{*}{$\mathrm{IC}_{50}(\mu \mathrm{g} / \mathrm{mL})$} \\
\hline & $\begin{array}{l}\text { starting } \\
\text { value }\end{array}$ & $\begin{array}{l}\text { minus } \\
\text { blank }\end{array}$ & $\begin{array}{l}\text { inhibition } \\
\text { ratio }\end{array}$ & $\begin{array}{l}\text { starting } \\
\text { value }\end{array}$ & $\begin{array}{l}\text { minus } \\
\text { blank }\end{array}$ & $\begin{array}{l}\text { inhibition } \\
\text { ratio }\end{array}$ & $\begin{array}{l}\text { starting } \\
\text { value }\end{array}$ & $\begin{array}{l}\text { minus } \\
\text { blank }\end{array}$ & $\begin{array}{l}\text { inhibition } \\
\text { ratio }\end{array}$ & \\
\hline \multicolumn{11}{|l|}{$( \pm)-15 \mathbf{a}$} \\
\hline 0 & 2.370 & 2.319 & - & 1.830 & 1.779 & - & 2.171 & 2.12 & - & Exp. 1: \\
\hline 50 & 1.569 & 1.469 & 36.654 & 1.481 & 1.381 & 22.372 & 1.539 & 1.439 & 32.123 & Exp. 2: \\
\hline 100 & 1.099 & 0.999 & 56.921 & 0.914 & 0.814 & 54.244 & 1.083 & 0.983 & 53.632 & Exp. 3: \\
\hline 150 & 0.486 & 0.386 & 83.355 & 0.447 & 0.347 & 80.495 & 0.570 & 0.47 & 77.83 & 81.087 \\
\hline 200 & 0.484 & 0.384 & 83.441 & 0.375 & 0.275 & 84.542 & 0.507 & 0.407 & 80.802 & \multirow[b]{2}{*}{$190 \mu \mathrm{M}$} \\
\hline 250 & 0.400 & 0.3 & 87.063 & 0.360 & 0.26 & 85.385 & 0.455 & 0.355 & 83.255 & \\
\hline \multicolumn{11}{|l|}{$( \pm)-16 \mathbf{a}$} \\
\hline 0 & 2.370 & 2.319 & - & 1.830 & 1.779 & - & 2.171 & 2.12 & - & Exp. 1: \\
\hline 50 & 1.977 & 1.877 & 19.06 & 1.698 & 1.598 & 10.174 & 1.982 & 1.882 & 11.226 & Exp. 2: \\
\hline 100 & 1.341 & 1.241 & 46.486 & 1.098 & 0.998 & 43.901 & 1.613 & 1.513 & 28.632 & Exp. 3: \\
\hline 150 & 0.311 & 0.211 & 90.901 & 0.286 & 0.186 & 89.545 & 0.348 & 0.248 & 88.302 & Avg: 97.344 \\
\hline 200 & 0.216 & 0.116 & 94.998 & 0.229 & 0.129 & 92.749 & 0.226 & 0.126 & 94.057 & \multirow[b]{2}{*}{$298 \mu \mathrm{M}$} \\
\hline 250 & 0.183 & 0.083 & 96.421 & 0.154 & 0.054 & 96.965 & 0.181 & 0.081 & 96.179 & \\
\hline \multicolumn{11}{|l|}{$( \pm)-16 \mathbf{b}$} \\
\hline 0 & 2.302 & 2.251 & - & 2.445 & 2.394 & - & 2.438 & 2.387 & - & 134.798 \\
\hline 50 & 2.059 & 2.015 & 10.484 & 2.217 & 2.173 & 9.2314 & 2.341 & 2.297 & 3.7704 & Exp. 2: \\
\hline 100 & 1.715 & 1.671 & 25.766 & 1.763 & 1.719 & 28.195 & 1.665 & 1.621 & 32.09 & Exp. 3: \\
\hline 150 & 1.122 & 1.078 & 52.11 & 0.696 & 0.652 & 72.765 & 0.665 & 0.621 & 73.984 & 127.369 \\
\hline 200 & 0.490 & 0.446 & 80.187 & 0.420 & 0.376 & 84.294 & 0.380 & 0.336 & 85.924 & \multirow[b]{2}{*}{$353 \mu \mathrm{M}$} \\
\hline 250 & 0.401 & 0.357 & 84.14 & 0.318 & 0.274 & 88.555 & 0.217 & 0.173 & 92.752 & \\
\hline \multicolumn{11}{|l|}{$( \pm)-17$} \\
\hline 0 & 302 & 2.251 & - & 2.445 & 2.394 & - & 2.438 & 2.387 & - & $178 . .641$ \\
\hline 50 & 1.871 & 1.7615 & 2.787 & 1.763 & 1.6535 & 14.724 & 2.146 & 2.102 & 6.61928 & Exp. 2: \\
\hline 100 & 1.828 & 1.7185 & 5.160 & 1.548 & 1.4385 & 25.812 & 1.949 & 1.905 & 15.37095 & Exp. 3: \\
\hline 150 & 1.248 & 1.1385 & 37.169 & 0.999 & 0.8895 & 54.126 & 1.354 & 1.31 & 41.80364 & Avg: 193.777 \\
\hline 200 & 1.030 & 0.9205 & 49.200 & 0.922 & 0.8125 & 58.097 & 0.882 & 0.838 & 62.7721 & \multirow{2}{*}{$489 \mu \mathrm{M}$} \\
\hline 250 & 0.872 & 0.7625 & 57.919 & 0.741 & 0.6315 & 67.432 & 0.850 & 0.806 & 64.19369 & \\
\hline
\end{tabular}

\section{- References}

1. van der Westhuyzen, A. E.; Hadjegeorgiou, K.; Green, I. R.; Pelly, S. C.; van Otterlo, W. A. L. Synthesis of pyrrolocarbazoles with $N$-substituted alkynyl-, alkylcyano- and alkylhydroxyl-groups. ARKIVOC 2020, 129-147.

2. Uredi, D.; Motati, D. R.; Watkins, E. B. A Unified Strategy for the Synthesis of $\beta$-Carbolines, $\gamma$-Carbolines, and Other Fused Azaheteroaromatics under Mild, Metal-Free Conditions. Org. Lett. 2018, 20, 6336-6339.

3. Jiang, X.; Yang, J.; Zhang, F.; Yu, P.; Yi, P.; Sun, Y.; Wang, Y. Facile Synthesis of 3-Halobenzo-heterocyclic-2-carbonyl Compounds via in situ Halogenation-Oxidation Adv. Synth. Catal. 2016, 358, 2678-2683.

4. Li, X.; Zhang, B.; Zhao, W.; Yang, S.; Yang, X.; Zhou, L. New 2-Aryl-6-methyl-3,4-dihydro- $\beta$-carbolin-2-iums as Potential Antifungal Agents: Synthesis, Bioactivity and Structure-Activity Relationship. Scientific Rep. 2019, 9, 1-12.

5. Hou, Z.; Zhu, L.-F.; Yu, X.-c.; Sun, M.-Q.; Miao, F.; Zhou, L. Design, Synthesis, and Structure-Activity Relationship of New 2-Aryl-3,4-dihydro- $\beta$-carboli-2-ium Salts as Antifungal Agents. J. Agric. Food Chem. 2016, 64, 2847-2854.

6. Herlé, B.; Wanner, M. J.; van Maarseveen, J. H.; Hiemstra, H. Total Synthesis of (+)-Yohimbine via an Enantioselective Organocatalytic Pictet-Spengler Reaction. J. Org. Chem. 2011, 76, 8907-8912. 